Maria de Lourdes Nogueira

\title{
Ensino de Projeto no Primeiro Ano e Suas Abordagens
}

\author{
Área de concentração: Projeto de Arquitetura \\ Orientadora Prof. Dra. Helena Aparecida Ayoub Silva \\ Co-orientador Prof. Dr. Oreste Bortolli
}

FAU-USP

São Paulo 2009 
Com os conhecimentos e tecnologias de que dispomos, como conceber arquiteturas para hoje, hodiernas, com a propriedade e a magnificência do passado? Como ensiná-las? Tínhamos a obrigação de fazer melhor. Construtores egípcios, gregos, romanos, templários, todos os sábios da China, Japão e Rangum, Borromini, Brunelleschi e Michelangelo, com mínima ciência sabiam tanto!

J oaquim Guedes, "Geometria Habitada" no prefácio Eupalinos ou O Arquiteto. Valery, Paul.Rio de Janeiro: Ed.34, 1996. 
Ao meu pai, Bira, pela forte lembrança dos seus ensinamentos...

À minha mãe, Eron, pela persistência e entusiasmo durante esta jornada... 


\section{Agradecimentos}

Gostaria de agradecer às seguintes pessoas:

- Tia Dirce, Tio Tolstoi e Tio Paulo pelo carinho;

- Beto e Mai, por transformarem e valorizarem a arte final;

- Luiz Claudio e Paulo Rozani pelo incentivo;

- Rosa Sposto pelo apreço;

- Denise Pessoa por ter me indicado o meio acadêmico;

- Ivanir por compartilhar o aprendizado na docência;

- Renata e Hamish pela profunda amizade;

- Janise e Wilson por estarem sempre próximos;

- Sylvia Dobry pelas conversas edificantes;

- Carlos Zahn pelo coleguismo e atenção;

- Barossi, Zanettini e Paula Katakura pela contribuição singular;

- Edgard Georges por me emprestar os seus traços;

- Edna pela "vibe" positiva;

- Álvaro Puntoni pelos esclarecimentos na qualificação;

- Ivete pela constante presença;

- Edu pelas S.M.S.S;

- Camila, Rô, Ana e Kika pela compreensão;

- Tia Del, Vó Zica e Vó América pelos ensinamentos;

- Akemi e turma da Eron pelas palavras animadoras;

- Funcionários da FAUUSP e FAU - Maranhão pela gentileza;

- Meus primos pelos mails e MSNs;

Em especial:

- Joaquim Guedes, in memoriam, pelo eterno aprendizado;

- Helena Ayoub pela valiosa recolhida,

- Oreste pela orientação clara e precisa. 


\section{SUMÁRIO}

Resumo

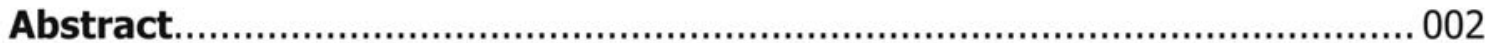

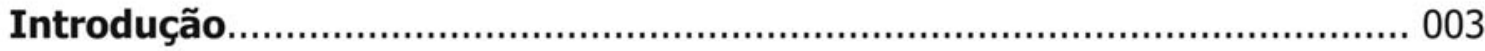

Capítulo 01

Considerações sobre a Transmissão de Conhecimento

na Universidade Brasileira.................................................................... 006

I Modelo Jesuítico e o Ratio Studiorum.......................................................... 008

II - Modelo Francês e os Cursos Profissionalizantes........................................... 013

III - Modelo Franco-Napoleônico e o Papel do Estado........................................... 013

IV - Modelo Alemão e o Incentivo à Ciência e a Pesquisa....................................... 015

\section{Capítulo 02}

Breve Histórico do Ensino Superior Brasileiro............................................ 019

I Ensino Superior Brasileiro a partir de 1990................................................ 029

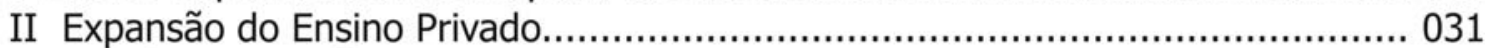

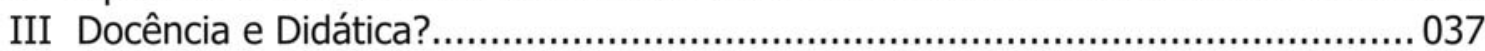

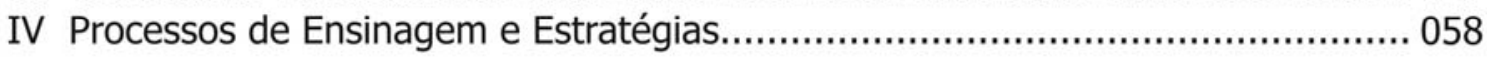

\section{Capítulo 03}

A Docência no Ensino Superior de Arquitetura.......................................... 062

I O Novo Papel do Professor-Arquiteto.............................................................. 063

II Temas de Ensino de Projeto Arquitetônico no Primeiro Ano da Graduação.......... 073

III O Projeto de Uma Livraria, Uma Estratégia ..................................................... 085

Capítulo 04

Visões e Divergências: Universidades Públicas.........................................107

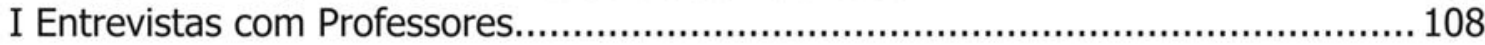

Capítulo 05

Visões e Divergências: Universidades Privadas......................................... 127

I Entrevistas com Coordenadores de Curso de Graduação..................................... 128

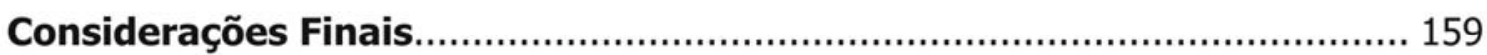

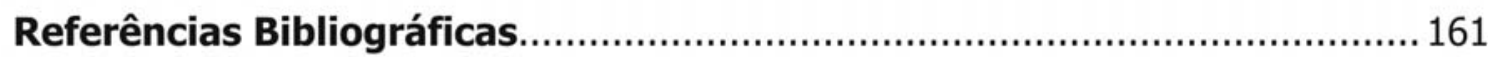

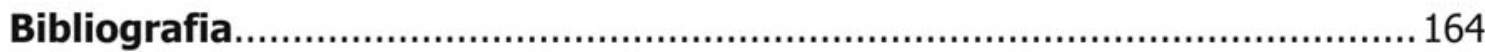




\section{Resumo}

O tema do doutorado foi realizado com o intuito de esclarecer algumas controvérsias a respeito das questões de transmissão de conhecimento e os seus graus de influência no ensino superior brasileiro atual.

Por meio de modelos de transmissão de conhecimentos seculares que se observa a distância entre os atos de ensinar e aprender, especialmente na disciplina de projeto arquitetônico no primeiro ano.

Como dizer que a arquitetura não pode ser ensinada, mas pode ser aprendida? Como os arquitetos-professores-pesquisadores enfrentam o desafio utilizando novas formas de ensinar e estratégias que propiciem a aprendizagem do saber arquitetônico?

São questões relevantes para a formação do arquiteto que são levantadas e analisadas amplamente.

Afinal, como dizia J oaquim Guedes:

Poetas, dizem, não se fazem nas faculdades de letras. Mas as de arquitetura têm que formar arquitetos. 


\begin{abstract}
The subject of the doctorate was brought about by the intention to highlight a number of controversies in respect of how to transmit knowledge and its degrees of influence in current Brazilian tertiary education.

Through models of knowledge dispersion we are able to observe the distance between the act of teaching and that of learning, especially in respect to the discipline architectural projects for first year students.

How can it be said that architecture cannot be taught, yet can be learnt? How do architects-teachers-researchers confront the challenge using new forms of teaching and strategies that propitiates the art of architecture?

These are relevant questions that are fundamental to the formation of an architect that are raised and analyzed in depth.

After all, J oaquim Guedes said:

Poets, they say, are not formed in the faculties of literature. Yet those of architecture have to form architects.
\end{abstract}




\section{Introdução}

A questão da eficácia da aula tradicional tem suscitado vários estudos em diversas áreas do conhecimento.

A aula expositiva ou teórica, como se costuma chamar é, na maioria das vezes, uma justificativa para o desempenho dos estudantes em geral. $\mathrm{Na}$ própria Faculdade de Arquitetura e Urbanismo da Universidade de São Paulo FAUUSP comenta-se que por meio da aula teórica, o estudante pode não ter aprendido, mas que o professor ensinou, ensinou.

Mas como é feita a transmissão de conhecimento dentro do curso de graduação de arquitetura? Como é a formação e qual o modo dos professoresarquitetos apresentarem conteúdos aos estudantes da graduação em arquitetura?

Será que quando se questiona o fato da aula de projeto arquitetônico não fluir, não seria o caso de empreender um debate na faculdade onde os arquitetos-professores são formados?

Estas e outras questões fazem parte das inquietações iniciais para 0 desenvolvimento desta tese.

Desde então, a tese se orientou para entender a origem e os caminhos da origem da aula expositiva tradicional, herança do modelo jesuítico, na universidade brasileira.

Este modelo se caracterizava por incutir no estudante a atividade mental de memorização, como instrumento de aprendizado. A atividade da memória é muito mais abrangente que só memorização de conteúdos explicitados. Em uma definição de Carsalade (2003 apud LARA e MARQUES, 2003, p. 148), o autor destaca:

"A memória é o relato vivo e pessoal de acontecimentos, coisas e lugares, mas também de sensações e emoções a eles ligados, de forma a se constituir num patrimônio de experiências vividas e, portanto, de extrema significação. Quando o uso da memória se faz apenas como retenção de fórmulas ou conteúdos se torna, no mínimo, uma utilização superficial e pequena de todo o seu potencial." 
Com o intuito de ampliar as possibilidades de aprendizagem pelos estudantes de arquitetura em bases teóricas, o tema desta tese seguiu um caminho que possibilitassem um melhor entendimento do ensino e aprendizagem do ato de projetar.

Desta forma, o Capítulo 01, denominado CONSI DERAÇõES SOBRE A TRANSMISSÃO DE CONHECIMENTO NA UNIVERSIDADE BRASI LEI RA, resgata o período da colonização onde os padres jesuítas por meio de um manual intitulado Ratio Studiorum exigiam uma forma de transmissão de conhecimento fundamentada em aulas expositivas e sua respectiva compreensão.

Com graus de influência menores são citados a seguir outros modelos que também influenciaram os métodos de ensino aplicados nas universidades brasileiras: o modelo francês, o modelo franco-napoleônico e o modelo alemão.

O Capítulo 02, denominado BREVE HISTÓRICO DO ENSINO SUPERIOR BRASILEIRO, reconstitui a historicidade da universidade brasileira, enfatizando o período após o ano 1990, quando ocorreu de forma expressiva a expansão do ensino privado nas Faculdades de Arquitetura e Urbanismo. Este capítulo trata também de questões relativas à docência e a didática de uma forma geral. 0 capítulo encerra-se ao abordar uma situação de ensino da qual necessariamente decorra a aprendizagem, sendo a parceria entre professor e alunos, a condição fundamental para esta realização.

No Capítulo 03, A DOCÊNCIA NO ENSINO SUPERIOR DE ARQUITETURA, continuando o enfoque sobre o aumento das instituições de ensino superior privado, são feitas reflexões referentes à formação, exercício e qualidade da docência nas Faculdades de Arquitetura e Urbanismo.

É o momento em que se analisa a abordagem de diversos temas utilizados nos cursos introdutórios de Projeto Arquitetônico 1 e respectivos comentários. É também no Capítulo $\mathbf{0 3}$ que após vários temas testados decidiu-se renovar a estrutura do curso de projeto arquitetônico.

Foi proposto como tema e estratégia uma Livraria, devido à uma série de aspectos relevantes explicitados neste capítulo.

Este foi o capítulo em que foram incluídas fotos de maquetes e desenhos da conclusão dos trabalhos das turmas de 2004 e 2005, para ilustrar esta técnica de ensino.

Nos capítulos restantes Capítulo 04 e 05, denominados VISÕES E DIVERGÊNCIAS são mostrados e comentados o ponto de vista de quatro professores de diferentes instituições de ensino superior - públicas e privadas em uma série de dez pontos, a saber: 
1 - Nível de formação dos alunos que cursaram o ensino médio;

2 - A expansão do número das Instituições de Ensino Superior no Curso de Arquitetura e Urbanismo;

3 - O Projeto Pedagógico e os Cursos de Arquitetura e Urbanismo;

4 - 0 conteúdo da disciplina de Projeto de Arquitetura 1;

5 - 0 mercado de trabalho e a formação do arquiteto;

6 - 0 arquiteto e o perfil profissiográfico ;

7 - 0 ensino do desenho no primeiro ano da graduação;

8 - A presença da história nas aulas de Projeto;

9 - Exercícios Projetuais envolvendo simulação;

10 - Carga Horária das disciplinas projetuais;

O propósito deste levantamento é por meio de uma entrevista, ressaltar as colocações relevantes acerca dos trabalhos efetuados em suas determinadas faculdades junto aos cursos das disciplinas de Projeto Arquitetônico, em especial, o primeiro semestre.

Este será o contexto que será detalhado nas páginas seguintes. 
Capítulo 01: CONSIDERAÇÕES SOBRE A TRANSMISSÃO DE CONHECIMENTO NA UNIVERSIDADE BRASILEIRA:

I - MODELO JESUÍTICO E O RATIO STUDIORUM II - MODELO FRANCÊS E OS CURSOS PROFISSIONALIZANTES III - MODELO FRANCO-NAPOLEÔNICO E O PAPEL DO ESTADO IV - MODELO ALEMÃO E O INCENTIVO À CIÊNCIA E A PESQUISA 


\title{
QUESTÕES SOBRE A TRANSMISSÃO DE CONHECIMENTO E OS GRAUS DE I NFLUÊNCI A NA UNI VERSI DADE BRASI LEI RA
}

Frequentemente, nota-se uma preocupação com a relevância da aula expositiva tradicional, alvo de muitas reclamações por parte dos alunos.

Essa técnica parece não estar dando certo, porque no momento das avaliações institucionais, 0 aluno comumente não se recorda dos conteúdos estudados, como é demonstrado nos resultados do provão ${ }^{1}$.

Além disso, o problema dos baixos índices do provão é que várias instituições de ensino superior passam a pautar o seu ensino de acordo com as respostas dos resultados dos anos seguintes ao provão. Quanto a isso, 0 geógrafo Miltom Santos adverte (1998 apud ANASTASIOU e ALVES, 2005, p.173):

\begin{abstract}
"A tirania da informação não é apenas a mídia, porque inclui também o nosso trabalho na universidade. Quero instituir nesta tecla, porque o nosso trabalho como professores é a base com o qual se educam e reeducam as gerações. Quanto mais 0 nosso trabalho for livre, mais educaremos para a cidadania. Quanto mais o nosso trabalho for acorrentado, mais estaremos produzindo individualidades débeis. É urgente que o ensino tome consciência dessa situação para esboçar a merecida reação, sem o que corremos o grande risco de ficar cada vez mais distantes da busca ideal da verdade".
\end{abstract}

No curso superior de arquitetura essa preocupação vem de encontro às recentes pesquisas direcionadas ao surgimento e formação dos professores universitários.

O principal intuito deste trabalho é apresentar alguns elementos que auxiliem o entendimento de alguns aspectos pedagógicos encontrados na universidade brasileira desde o seu princípio. Para isso serão mostrados alguns modelos que a influenciaram e deixaram marcas na sua constituição, destacando a função institucional, a visão do conhecimento dominante, o papel esperado do docente e do estudante.

1 Exame Nacional de Cursos de Graduação, criado pela Lei 9.131/95. Tem por objetivo alimentar os processos de decisão e de formulação de ações voltadas para a melhoria dos cursos de graduação. 
Ao observar as relações existentes entre o docente e o estudante, deve-se admitir que 0 ato de ensinar seja um dos principais elementos da ação docente. A palavra ensinar se origina do latim insignare, e significa marcar com um sinal ou deixar uma marca. Ensinar corresponde a explicar ou apresentar o conteúdo numa exposição conforme Anastasiou e Alves (2007, p.18).

As instituições onde são desenvolvidos os cursos de graduação e pós-graduação no Brasil têm sido os locais onde têm ocorrido discussões sobre o nível de ensino nas universidades. Os pontos mais discutidos como informam Anastasiou e Alves (2007, p.17) tem sido:

- As novas formas de ensinar que propiciem a aprendizagem,

- A qualidade da formação dos professores universitários.

A reflexão sobre o contexto aonde as aulas são ministradas, a sua formação histórica assim como as concepções teóricas e as tendências pedagógicas envolvidas serão apresentadas, considerando o ambiente atual das faculdades de arquitetura em geral.

\section{I - O MODELO J ESUÍ TI CO E O RADI O STUDI ORUM}

Historicamente, o ato de ensinar está relacionado à colonização das terras brasileiras pelos portugueses. Em 1599 foi publicado pelos padres jesuítas, um manual intitulado Ratio Studiorum, composto de trinta conjuntos de regras com a finalidade de ordenar as atividades, funções e os métodos de avaliação nas escolas jesuíticas. Esse manual de organização e administração escolar descrevia o que os mestres deveriam ensinar ao definir os três atos básicos de uma aula:

- Preleção do conteúdo pelo professor;

- Levantamento de dúvidas dos alunos,

- Exercícios para fixação.

No entanto, segundo ainda Anastasiou e Alves (2007, p.17) a importância do Ratio Studiorum pode ir além dessas três ações fundamentais. 0 método de ensino elaborado pelos jesuítas se estendeu por toda a Europa e em regiões de ocupação do Novo Mundo, com o principal 
objetivo de difundir o catolicismo a todos que viviam nos territórios recém descobertos. Para Bortoloti (2003) ${ }^{2}$ esse manual era tão detalhista que tratava da indicação de responsabilidade, do desempenho, da subordinação e do relacionamento entre os membros da Companhia de Jesus, de professores a alunos. Esse cuidado permitia uma formação uniforme a todos que freqüentassem colégios jesuítas em qualquer região do mundo.

Já para Lima $\left(2007\right.$, p1.) ${ }^{3}$ os preceitos do Ratio iam além de um método de ensino. Era principalmente um modo de expandir a fé cristã, utilizando o ensino para promover a religião em uma época em que a Igreja Católica precisava reagir contra o movimento protestante, para não perder a sua hegemonia. Dessa forma, a Companhia de Jesus foi utilizada para transformar os habitantes "bárbaros" do Novo Mundo em cidadãos católicos. 0 trabalho de escolarização estava inserido em um contexto em que 0 cristianismo visava poder manter-se, propagar sua doutrina e assegurar 0 exercício do culto, explica Ullmann (1994 apud ANASTASIOU e PIMENTA, 2005, p. 144).

Entretanto, Bortoloti (2003) salienta que esse difícil trabalho de catequização foi iniciado com os nativos indígenas, e mais tarde com os colonos. Porém essas tentativas de conversão fracassaram por causa da efemeridade da crença dos nativos, que rapidamente retornavam aos antigos costumes. Mas esse fato não desanimou os jesuítas que trataram de buscar soluções eficazes para a concretização de seus ideais. Tais soluções foram a educação e a catequese dos meninos índios e a formação dos aldeamentos, dentro dos quais os indígenas viveriam sob uma nova organização, dirigida pelos padres e educados para se adequarem às regras da colônia.

0 modelo jesuítico como explicam Anastasiou e Pimenta (2005, p.146), procurava manter-se na vida das pessoas, estendendo a sua doutrina católica a outras regiões e conservando o exercício do culto. Notadamente rígido esse modelo assemelhava-se à estrutura militar no que tangia a unidade e a hierarquia da organização dos estudos. Não era permitido avançar para uma etapa superior sem que a anterior estivesse totalmente aprendida.

conhecimento transmitido era tido como algo posto, pronto e

\footnotetext{
2 BORTOLOTI, Fernanda da Silva. O Ratio Studiorum e a Missão no Brasil. Revista História Hoje.Revista Eletrônica de História, V.1N.2.UNESP, Franca, dezembro 2003. Disponível em: < http://www.anpuh.uepg.br/historia-hoje/vol1n2/vol1n2.htm> Acessado em 17/11/2009.

${ }^{3}$ LIMA, Daniela Fernanda Cardoso Forster. Ratio Studiorum: Método Pedagógico dos Jesuítas. UNIMEP, 2007. Disponível em:

$<$ http://www.unimep.br/phpg/mostraacademica/anais/5mostra/5/31.pdf > Acessado em $10 / 12 / 2008$.
} 
indiscutível, $\mathbf{e}^{\mathbf{4}}$ assim devia ser repassado aos alunos e memorizado. Ao professor cabia a missão de explicitar o conteúdo, aos alunos era imprescindível a memorização do que era dito e anotado.

Um dos aspectos dessa metodologia pedagógica é a deturpação da forma de transmissão do conhecimento: uma reles explicação do conteúdo de uma disciplina, onde muitas vezes os elementos históricos e contextuais eram ignorados, poderia ser chamada de aula $^{5}$, explica Reboul (1982 apud ANASTASIOU e ALVES, 2007, p.18).

Era com um comportamento inerte e indiferente, que os alunos tomavam a simples informação como conhecimento, Reboul (2007 apud ANASTASIOU e ALVES, 2007, p.18):

"O aluno registra palavras ou fórmulas sem compreendê-las. Repete-as simplesmente para conseguir boas classificações ou para agradar o professor [...]; habitua-se a crer que existe uma "língua do professor", que tem de aceitar sem a compreender, um pouco como a missa em latim [...]".

Esse aspecto fica mais claro na afirmação de Anastasiou e Alves (2007, p. 18):

\begin{abstract}
"Nesse processo ficam excluídas as historicidades, os determinantes, os nexos internos, a rede teórica, enfim, os elementos que possibilitaram aquela síntese obtida; a ausência desses aspectos científicos, sociais e históricos deixa os conteúdos soltos, fragmentados, com fim em si mesmos “.
\end{abstract}

Hoje, de acordo com Anastasiou e Pimenta (2005, p.147) dentro das salas de aula verifica-se a influência do modelo jesuítico na universidade brasileira. A metodologia aplicada atualmente corresponde a maneira que nossos antepassados viam 0 ato de lecionar. A explanação dos conteúdos, as dúvidas levantadas pelos alunos e até mesmo as sabatinas realizadas uma vez por semana aos sábados, explica Bortoloti (2003) foram ditados pelo Ratio.

\footnotetext{
${ }^{4}$ Grifos da autora.

${ }^{5}$ Grifos da autora.
} 
A causa da influência jesuítica no ensino transformou o aluno em um ser passivo na maioria das vezes, onde a sua atuação principal consistia em memorizar o conteúdo para poder realizar avaliações eficientes.

O programa básico de estudo, informa Anastasiou e Alves (2007, p. 144-145) do modelo jesuítico era composto pelo Trivium que abrangia a aprendizagem de Gramática, Retórica e Dialética, e o Quadrivium, que abrangia Aritmética, Geometria, Astronomia e Música.

No método escolástico eram fundamentais: a lectio, que consistia na leitura do texto e na sua interpretação pelo professor, mais análise de palavras, o destaque de idéias e a sua comparação com outros autores, e a questio que consistia na pergunta do professor aos alunos, e dos alunos ao professor, conforme relatam Anastasiou e Alves (2007, p.145-146).

Durante as aulas, os alunos realizavam a reportationes, ou seja, anotações para serem memorizadas em exercícios, e usavam um caderno para loci communes em que registravam assuntos e frases significativas, palavras e pensamentos ou citações ${ }^{6}$. Quando 0 texto suscitava dúvidas, surgiam a quaestiones, indagações feitas pelos alunos ou pelos professores para esclarecer dúvidas. Delas surgiam as disputiones entre professor e aluno, ou só entre os alunos. 0 início da aula era precedido de verificação da lição anterior, chamada lectione reddere e semanalmente, realizava-se uma recapitulação de toda a matéria. Resumindo, lectio, quaestio, reparatio, disputatio, eram os momentos de ensino. A elaboração ordenada do material era retomada e organizada pelo professor - determinato magistri - e depois escrita pelo mestre ou aluno. A atividade seguinte era a de exposição, argumentos a favor, argumentos contra a solução do mestre. Este era o método escolástico que visava à colocação exata e analítica dos temas a serem estudados, clareza nos conceitos e definições, argumentação precisa e sem digressões, expressão rigorosa, lógica em latim. 0 ensino era eminente oral (a imprensa só veio a ser inventada em 1453).

Apresentando estas características, o método escolástico predominou em várias universidades européias como a Universidade de Paris, onde se constituiu o modus parisiensis.

A formação e a personalidade de cada professor - um sacerdote constituíam elementos fundamentais para o sucesso do método jesuítico.

O método alcançava eficácia na aprendizagem porque atendia várias etapas: unidade e hierarquia da organização dos estudos, na divisão, e na graduação das classes e programas, em extensão e dificuldade. Ter

${ }^{6}$ Considerar a inexistência da imprensa e a cópia dos livros existentes, um a um. 
obrigatoriedade de vencer a etapa em questão. O conhecimento é indiscutível, indubitável e, portanto repassado usando a memorização como operação essencial deste processo de aprendizagem. 0 professor é o repassador do conteúdo a ser memorizado em uma aula expositiva, acompanhado de exercícios, a avaliação/emulação/castigos, o controle rígido dentro e fora da sala de aula. Um aluno passivo e obediente que memoriza o conteúdo para a avaliação. Enfim, um modelo que acaba de completar quinhentos anos.

A base do modelo, comum em todas as escolas jesuíticas, independentemente do país em que se encontravam, estava na unidade e hierarquia da organização de estudos, na divisão e na graduação das classes, nos programas em extensão e dificuldade na memorização como operação necessária, num modelo de aula expositiva com um aluno passivo e obediente ${ }^{7}$ :

"O modelo jesuítico encontra-se, pois, na gênese das práticas e modos de ensinar presentes nas universidades, configurando-o como um habitus, isto é, um conjunto de esquemas que permite engendrar uma infinidade de práticas adaptadas a situações sempre renovadas, sem nunca constituir princípios explícitos", Bordieu (1991 apud ANASTASIOU e PIMENTA 2005, p.147).

Atualmente, o docente universitário não precisa utilizar um manual como no momento jesuítico inicial. Sua ação docente é fundamentada mais no senso comum de como ensinar, porém a preleção, a memorização, a avaliação, o castigo permanecem. Luckesi (1994 apud ANASTASIOU e PIMENTA, 2005, p. 148) o define como conceitos, significados e valores que adquirimos espontaneamente, pela convivência, no ambiente em que vivemos. $\mathrm{E}$, de acordo com esse senso comum vigente, para ser professor no sistema de ensino escolar, as autoras Anastasiou e Pimenta (2005, p. 148) enfatizam:

[...] "basta tomar certo conteúdo, preparar-se para apresentálo ou dirigir o estudo; ir a uma sala de aula, tomar conta de uma turma de alunos e efetivar o ritual da docência, que consiste em apresentar os conteúdos, controlar os alunos, avaliar a aprendizagem, disciplinar".

\footnotetext{
${ }^{7}$ Notar a semelhança deste processo com os dias atuais.
} 


\section{II - MODELO FRANCO-NAPOLEÔNI CO E AS ESCOLAS PROFI SSI ONALIZANTES}

Como conseqüência de um pacto colonial entre as nações européias, teve início em 1808 o ensino superior no Brasil, com a criação das escolas isoladas. Antes disso, os brasileiros eram enviados à Europa para efetuar os seus estudos e obter o título de bacharéis e doutores.

A principal característica das escolas isoladas era ser uma organização não universitária, porém profissionalizante, centrada em cursos e faculdades. Visavam à formação de burocratas para o desempenho das funções do Estado e tinham como finalidade proceder a uma unificação ideológica:

"Trata-se de prevenir contra as teorias perniciosas e subversivas da ordem social, de resistir às teorias perigosas, e outras, que em todos os povos, atormentaram freqüentemente a opinião pública". Boaventura (1989 apud ANASTASIOU e PIMENTA, 2005, p.149)

Quanto ao corpo docente, disse que:

[...] "a corporação de professores se caracteriza primeiramente pela fixidez. Formemos um corpo de doutrinas que não varie nunca e uma corporação de professores que não morra nunca. Não haverá Estado Político fixo se não houver uma corporação de professores com princípios fixos." Boaventura (1989 apud ANASTASIOU e PIMENTA, 2005, p.149)

Sua organização administrativa estabelecia um modelo de universidade centralizador e fragmentado. Como impossibilitava e dificultava processos divergentes de pensamento tornou-se uma escola impositiva.

\section{III - MODELO FRANCÊS E O PAPEL DO ESTADO}

Teve início no Brasil no tempo das escolas isoladas e sua grande preocupação estava voltada para a formação dos quadros profissionais, atendendo com prioridade a elite. Os alunos tinham que ter o domínio da 
língua francesa que se preconizava até a criação de colégios femininos, de acordo com esse modelo, visando à formação de futuras esposas de diplomatas.

As diferenças entre a América espanhola e a América portuguesa puderam ser constatadas na implantação do ensino superior. Enquanto em 1558 foi criada no Peru a primeira universidade, no Brasil o ensino superior se iniciou com a vinda da família real em 1808, como relata Anastasiou e Pimenta (2005, p.148). Foram criadas escolas isoladas, cujo modelo adotado denominou-se franco-napoleônico. Esse modelo se caracterizava por constituir uma organização não universitária, mas profissionalizante, pretendendo como objetivo formar burocratas para desempenhar as funções do Estado. Era um modelo de universidade centralizador e fragmentado, onde a preocupação central era a formação de quadros profissionais que atendesse prioritariamente a elite, ou seja, era um modelo de universidade que se submetia aos interesses do Estado. 0 fato da língua francesa e da língua portuguesa pertencer a mesma origem latina, favoreceu a influência cultural francesa no período do estabelecimento da família real portuguesa no Brasil.

O modelo francês ou napoleônico tinha como meta a obtenção de um título reconhecido pelo Estado. A organização acadêmica era feita por faculdades ou por objetos de estudo. De acordo com cada um, eram formados os conjuntos de disciplinas, rigidamente determinados. Os cursos continham um período básico e outro profissionalizante, aonde a teoria vinha antes da prática, e os estágios aconteciam no final do currículo de cada curso. Anastasiou e Pimenta (2005, p. 150)

As características próprias do modelo francês são idênticas ao modelo jesuítico: a relação entre professor, aluno e conhecimento se mantém. 0 professor é considerado o transmissor do conhecimento e, no estudo das obras clássicas, a aceitação das atividades propostas, a memorização do conteúdo pelo aluno, a avaliação como elemento classificatório.

É nesse modelo que o Estado é o responsável direto pela nomeação das autoridades universitárias, explica Anastasiou e Alves (2007, p. 50). A unidade e identidade dos planos docentes e acadêmicos para titulação ficavam estabelecidas pelo controle do Estado.

Pode-se verificar a grande semelhança existente entre a proposta de dois séculos atrás e a configuração das disciplinas em grade curricular encontrada hoje em grande parte das instituições de ensino superior. 
Outro ponto em comum é a separação da teoria da prática e a distinção entre as disciplinas do básico e do profissionalizante com um conjunto de requisitos e pré-requisitos.

Soma-se ainda o fato dos cursos serem anuais ou semestrais e as disciplinas destinadas a um docente que se tornava responsável por uma parte do currículo. Dessa forma cada professor organizava seu plano de ensino e trabalhava nele independente dos demais.

\section{IV - MODELO ALEMÃO E O I NCENTI VO À CI ÊNCI A E A PESQUI SA}

O modelo alemão ou humboldtiano foi criado na Alemanha, no final do século XIX, conforme informa Anastasiou e Pimenta (2005, p.150), em um momento em que a Alemanha perde o pioneirismo da Revolução Industrial para a França e a Inglaterra.

É proposto o avanço da ciência por meio da pesquisa das questões nacionais como saída para a renovação tecnológica num esforço deliberado de eliminar a dependência e estruturar a autonomia nacional.

A universidade se compromete com a questão de integração nacional e com a tentativa de incorporação da cultura alemã à civilização industrial, antecipando-se à industrialização e criando uma química e metalurgia altamente desenvolvidas, conforme Ribeiro (1975 apud ANASTASIOU 2005, p.151)

Suas principais características são:

- Busca desinteressada da verdade,

- Ciência investigada e esclarecida desinteressadamente, isto é, radicalmente independente de qualquer expectativa a respeito do objetivo que dela se fará futuramente, seja valendo como um instrumento político econômico ou qualquer outro.

A procura da busca da verdade é considerada como um valor absoluto e suficiente à própria auto-afirmação.

Esse modelo acha-se voltado para a resolução dos problemas nacionais mediante a ciência e pela pesquisa, unir os professores entre si e os alunos. Contém dois momentos de atuação: os institutos, visando a formação profissional, e os centros de pesquisa, que seriam regidos assim:

- Autonomia ante o Estado e a sociedade civil;

- Busca da verdade como caminho do desenvolvimento;

- Autoconsciência;

- Atividade científica criativa; 
- Processo cooperativo entre os docentes e entre estes e os discentes;

- Docência como atividade livre,

- Associação cooperativa entre professores e alunos sem forma de controle e organização acadêmica.

Numa proposta em que o professor não existe para o aluno, mas ambos para a ciência, explicam Anastasiou e Pimenta (2005, p.151), fica estabelecida uma relação em parceria que caminha em direção da construção do conhecimento. Não prevalece o papel do professor como transmissor de uma metodologia tradicional e autoritária. Ambos caminham para a construção do conhecimento.

O incentivo a pesquisa é apresentado como resolução para a área tecnológica o compromisso da universidade com a integração nacional e com a incorporação da civilização industrial. Com isso, a química e a metalurgia se desenvolveram tanto, ao ponto de levar o país a competir internacionalmente.

Porém em meados do século $X X, A$ América Latina é tomada por profundas transformações sociais, iniciando um processo de autonomia e conquista de participação na administração, com a entrada da classe média espanhola na universidade; deu-se a busca da independência nos assuntos lítero-científico culturais e como meta principal a liberdade de pensamento. No caso brasileiro, segundo Niuvenius ocorreu (entre meados de 50 a 64) um movimento de reforma subsidiado por toda uma efervescência política:

\footnotetext{
"Quando me refiro a projetos de reforma, penso nas diversas propostas que pretendiam uma "virada" num certo padrão dominante no ensino, o qual era criticamente referido como erudito, livresco, bacharelesco, vazio, atrasado, etc.[...] Discussões, experiências e propostas surgiram por vários motivos, inclusive como um possível efeito dos padrões de investigações científico/empírico/experimental/críticos, que foram emergindo no Brasil a partir dos anos 50[...]. Começavase a desenhar, então a perspectiva de um possível acúmulo constante dessa produção de conhecimento e sua socialização em termos de: a) incorporação dos resultados no nível de uma reformulação dos conteúdos curriculares; b) disseminação de formas e práticas de ensino que incorporavam, nas concepções, os procedimentos trazidos por esse tipo de investigação. Essa perspectiva de produção colocava a ação de pesquisar como fora de luta contra os problemas do atraso em que se encontrava o ensino escolarizado em todos os níveis
} 
de sua estrutura e organização. Niuvenius (1988 apud ANASTASIOU 2001, p.2).

As influências do modelo alemão atingiram a universidade brasileira na explicação de Anastasiou (2007, p. 54), na reforma da lei 5.440/68 ocasionada por um dos pacotes efetivado no convênio MEC/USAID. Nele encontramos elementos trazidos do sistema norte-americanos e que tinham sido copiados do modelo alemão. Principalmente quando se refere à função de pesquisa; a visão de ciência não é alterada.

Nos últimos anos, freqüentemente são iniciadas discussões acerca do significado do ensino e da aprendizagem. É comum no curso de arquitetura as pessoas proferirem: arquitetura não se ensina, mas se aprende.

É interessante verificar que essa duas ações podem ser vistas separadamente uma da outra, de forma disjunta. Alguns professores não importam qual seja a especialidade, tem afirmado: eu ensinei, o aluno que não aprendeu, conforme relatam Anastasiou e Alves (2007, p. 17).

Se a arquitetura não se ensina, como então afirmar que ela pode ser aprendida?

A idéia desse presente trabalho é trazer para o âmbito das faculdades particulares reflexões que tem sido realizadas sobre a questão da didática e estratégias de ensinagem nos cursos de pós-graduação de Educação e Pedagogia.

Como foram demonstrados no início desse capítulo, os três passos básicos de uma aula se originaram no Modelo J esuítico, por volta de 1600.

A aula era o espaço em que o professor explicava o conteúdo, cabendo ao aluno anotá-lo para depois memorizá-lo. Caso o estudante não comparecesse às aulas, ele teria facilmente acesso as anotações feitas por colegas, podendo somente dedicar-se a memorizá-las.

Outra influência que a universidade brasileira recebe do modelo alemão são as diretrizes contidas nas leis 5.450/68 - referente ao Ensino Superior e 5.692/71 referentes ao ensino de 10 e 20 graus, além do modelo organizacional francês

No entanto, o objetivo dessa tese é que o aluno avance de uma posição passiva de assistir as aulas onde além de aprender o conteúdo, passe a principalmente a apreendê-lo. 
Ou seja, o esforço é para que se atente que o modo tradicional de dar aulas se originou a centenas de anos atrás, em um tempo onde as transmissões de conhecimento eram fundamentalmente impositivas.

Procurou-se então no curso de arquitetura, encontrar uma forma ou uma estratégia que possibilite a apreensão por parte dos estudantes dos conteúdos ensinados, onde o professor e 0 aluno fazem as aulas e propiciam um aprendizado efetivo.

Ressalta desta forma, o clima de desenvolvimento pós-guerra, quando professores e pesquisadores declaravam necessidades de melhoria e de busca de soluções para os problemas econômicos e sociais da realidade.

Neste período, os três elementos característicos dos movimentos educacionais foram assumir o conteúdo como provisório, relativo, datado no tempo e no espaço, produto de um trabalho de investigação, portanto, passível de mudanças; a procura da criatividade concebendo o estudo como uma situação construtiva significativa. Finalmente, passar de uma situação a ser transmitida e assimilada para uma situação de busca de equilíbrio. E como constatação final:

“Considerando as concepções e práticas tradicionais, trazidas pelos jesuítas, que impregnaram fortemente o ensino em todos os níveis de escolaridade até os dias de hoje, constatamos que sua influência persiste com mais intensidade no ensino superior". Anastasiou e Pimenta (2005, p.227). 


\section{Capítulo 02: CONSIDERAÇÕES DO ENSINO SUPERIOR} BRASILEIRO

I - ENSINO SUPERIOR BRASILEIRO A PARTIR DE 1990

II - EXPANSÃO DO ENSINO PRIVADO

III - DOCÊNCIA E DIDÁTICA?

IV - PROCESSOS DE ENSINAGEM E ESTRATÉGIAS 


\section{BREVE HI STÓRI CO DO ENSI NO SUPERI OR BRASI LEI RO}

Os modelos de ensino, anteriormente descritos, influenciaram a formação e a constituição das universidades brasileiras que, no decorrer do tempo, sofreram várias reformas de acordo com o momento político e social. Os primeiros cursos universitários instituídos no Brasil foram a partir 1808 com a chegada da família real.

Inicialmente foram criados três institutos, explica Baroni (2008), que hoje se transformaram num conglomerado que abrigam mais de 2.480 universidades, faculdades e centros universitários, nestes 201 anos.

No Brasil, as principais capitanias, Bahia e Rio de Janeiro, lugares onde surgiram as primeiras faculdades que atendiam preferencialmente às elites. Suas vagas aumentaram consideravelmente ao ponto de atender um total de 5,9 milhões de brasileiros de várias regiões e todas as classes sociais.

Entretanto, apesar dos avanços, segundo o MEC, o número de jovens entre 18 e 24 anos fazendo algum curso superior é apenas $12,1 \%$ do número de brasileiros que deveria buscar a carreira universitária.

Dentro da América Latina o desempenho no campo do ensino superior também é modesto, porém o Brasil se situa atrás do Chile (21\%) e da Argentina (47\%) conta Baroni (2008).

Essa diferença marca 0 atraso da criação das instituições de ensino superior no país, onde a primeira faculdade só surgiu 308 anos após 0 descobrimento do país em 1500. Antes de 1600 foi instituída a primeira universidade do continente, no Peru. Tal fato se deve ao modo diferenciado que países como Espanha, França, Holanda e Inglaterra tratavam as suas respectivas colônias. Portugal não tinha planos de desenvolvimento para 0 Brasil, que era uma colônia de exploração.

Segundo Fredric Michael Litto, presidente da Associação Brasileira de Educação à Distância - ABED, Portugal se sentiu ameaçado porque as universidades seriam espaços que estimulavam as pessoas a serem mais críticas e isso iria contra os planos traçados pela Corte Portuguesa. Mas isso não significava que não havia acesso à educação profissionalizante. Estima-se que entre 1700 e 1800, conforme relata o livro 1808 de Laurentino Gomes, mais de 500 brasileiros foram estudar na Universidade de Coimbra onde a profissão mais procurada era Direito.

Outro fator que colaborou para o atraso no desenvolvimento do Ensino Superior Brasileiro foi a taxa de analfabetismo. Laurentino Gomes conta 
em seu livro que em 1818 na cidade de São Paulo apenas 2,5\% dos homens livres em idade escolar eram alfabetizados. Mesmo com a criação das primeiras faculdades no país, ainda não existiam livros traduzidos para a Língua Portuguesa e só a elite tinha acesso ao ensino.

Depois da Independência, o ensino superior brasileiro ainda foi negligenciado tanto pelo Império como pela República, relata Gilberto Gonçalvez Garcia, presidente do Conselho e Reitores das Universidades Brasileiras. Segundo ele, as modificações só ocorreram informa Baroni (2008), quando o Estado passou a ver a educação como fator principal no desenvolvimento da nação, mais precisamente, durante a Era Vargas. Nessa época foram criadas as bases para a formação do sistema educacional.

Segundo Ghiraldelli (1991, p. 165) a ditadura militar, por duas décadas - 1965 até 1985, se pautou em termos educacionais pela repressão, pela privatização ${ }^{8}$ do ensino, pela exclusão das classes populares do ensino elementar de boa qualidade ${ }^{9}$, pela institucionalização do ensino profissionalizante e pela desmobilização do magistério através de abundante legislação educacional.

"Se por lado, a partir do golpe de 1964, ampliou-se significativamente 0 ensino superior privado no Brasil, sobretudo pelo aumento das universidades federais, por outro havia incentivo à expansão do ensino superior privado".

Com respeito à educação, existia a Lei 4024/61, que refletiu os princípios liberais vivos na democracia relativa aos anos 50; e a Lei 464/64 também denominada Lei Suplicy que extinguiu a UNE União Nacional dos Estudantes - UNE.

Uma vez iniciado o novo regime, após a Revolução de 1964, a a política salarial de atividades agrícolas e comerciais, e, principalmente, educacional passaram a descontentar não somente as classes populares e setores médios, mas até mesmo as elites e classes médias altas que haviam dado o apoio ao Golpe pela ausência de uma democracia política.

\footnotetext{
${ }^{8}$ Sobre esse assunto, ver o capítulo III chamado "FAU-SJ C: o IPC- Instituto de Projeto e Comunicação" da tese de doutorado de Sylvia A. Dobry Pronsato (2008, pp.225-257) que tece importantes considerações acerca da expansão do Ensino Superior Privado.

9 Segundo dados do I.B.G.E., em 1983 o Brasil possuía 60 milhões entre analfabetos e semiletrados.
} 
Um exemplo claro deste descompasso entre os governos e os próprios interesses dessas classes, poderia ser observado em especial, na política educacional da ditadura e nas reformas do Ensino Universitário - Lei 5.540/68 e Ensino Médio - Lei 5692/71, conforme relata Ghiraldelli (1991, p. 167).

Entre julho de 1964 e janeiro de 1968 foram firmados doze acordos MEC- USAID ${ }^{10}$, que comprometeram a política educacional do país às determinações dos técnicos americanos, copiados inclusive do antigo modelo alemão. E foram instituídas as leis 5.540/68 - Reforma do Ensino Universitário e 5692/71 - Reforma do Ensino Médio.

É possível perceber a determinação do governo militar, quando o ministro Roberto Campos, em palestra sobre Educação e Desenvolvimento Econômico procurou demonstrar a necessidade de atrelar a escola ao mercado de trabalho. Sugeriu um vestibular mais rigoroso justificando a agitação estudantil daqueles anos devido a um ensino desvinculado ao mercado de trabalho, um ensino baseado em generalidades, segundo suas palavras, um ensino que, não exigindo praticamente trabalhos de laboratório, deixava vácuos de lazer que estariam sendo preenchidos com aventuras políticas, acrescenta Ghiraldelli (1991, p. 167)

o Ensino Médio deveria atender, segundo ele, a massa, em ganhar elementos utilitários e práticos, enquanto o ensino universitário deveria continuar reservado à classe privilegiada. Advogava publicamente a profissionalização da escola média com objetivos de contenção das aspirações ao Ensino Superior. 0 sistema Educacional não deveria despertar ensejos que não pudessem ser satisfeitos. A universidade em 1968 tornou-se um pólo de resistência ao regime ditatorial, várias faculdades foram tomadas pelos alunos. O governo tratou de criar Grupo de Trabalho da Reforma Universitária - GTRU. A ditadura militar criou então o Movimento Brasileiro de Alfabetização - Mobral. E para se fazer passar por eficaz, poderia utilizar o método Paulo Freire (1967).

A industrialização, capital internacional associado ao capital nacional, pautou-se pela expansão de uma produção de bens de consumo duráveis. Não houve interesse em fazer a expansão de bens de consumo popular, a não ser para exportação

0 ensino superior passou a significar a oportunidade de alguns setores ascenderem socialmente, de outros, a de não descerem com tanta velocidade. A Lei 5.580/68 implantou a reforma visando o abafamento da crise

\footnotetext{
10 MEC : Minitério de Educação e Cultura

USAID: United States Agency for International Development
} 
estudantil e atendendo os desejos dos setores médios em democratizar 0 acesso às universidades. Para facilitar a lei 5.540/68 criou a matrícula por departamentalização e a matrícula por disciplina, incluindo o curso parcelado adotando o regime de créditos. Estipulou 0 vestibular unificado e classificatório. Além do mais, o problema da democratização do ensino foi resolvido com o incentivo à privatização. 0 curso e o departamento eram os vínculos básicos da universidade, tanto para os professores como para os alunos.

De acordo com a Lei 5692/71, os anteriores cursos primários e 0 ciclo ginasial foram agrupados no ensino de $1^{0}$ grau para atender crianças e jovens de 7 a 14 anos, ampliando a obrigatoriedade freqüência dede 4 para 8 anos. $02^{0}$ grau tornou-se profissionalizante. 0 Conselho Federal de Educação C.F.E., por meio do parecer 45/72 relacionou 130 habilitações técnicas que poderiam ser adotadas pela escola, de acordo com o relato de Ghiraldelli (1991, p. 182). Depois o número dessas habilitações subiu para 158. Mas, não foram colocados recursos humanos e materiais para transformar toda uma rede de ensino em profissionalizante.

A qualificação para o trabalho proposta na Lei 5692/71, foi substituída pela preparação para o trabalho pela Lei 7.044/82, assim o $2 \stackrel{0}{\text { grau }}$ se livrou da profissionalização obrigatória. Em 20 de dezembro foi finalmente votada a Lei das Diretrizes e Bases da Educação Nacional, de número 9.394/96.

"A preparação para o exercício do magistério superior far-se-á em nível de pós-graduação, prioritariamente em programas de mestrado e doutorado. Parágrafo único: o notório saber, reconhecido por universidade com curso de doutorado em área afim, poderá suprir a exigência de título acadêmico". (LDBEN, ART. 66) ${ }^{11}$

Observe-se que essa lei não concebe a docência universitária como um processo em formação, mas sim como preparação para o exercício do magistério superior, que será realizado prioritariamente em pós-graduação stricto sensu.

\footnotetext{
${ }^{11}$ Estabelece as Diretrizes e Bases da Educação Nacional, LEI № 9.394,DE 20 DE DEZEMBRO DE 1996.
} 
A competência e a eficácia do docente será mensurada pelos resultados obtidos pelos alunos no provão ${ }^{12}$. As instituições serão avaliadas pelo índice de porcentagem de professores com títulos de mestrado e doutorado. O decreto 2.207/97 determina que, no segundo ano de sua vigência, as instituições de ensino superior deverão contar com $15 \%$ dos seus docentes titulados na pós-graduação stricto sensu, dos quais $5 \%$ de doutores pelo menos, no $5^{-0}$ ano de vigência, com $25 \%$ dos quais $10 \%$ de doutores pelo menos, e no $8^{0}$ ano de vigência, com $1 / 3$, dos quais $15 \%$ de doutores pelo menos, relatam Anastasiou e Pimenta (2005, p.40).

Porém, os programas de mestrado e doutorado nas mais diversas áreas, tem se voltado para a formação de pesquisadores em suas áreas. Então para se dedicar a docência é preciso percorrer os caminhos da pós-graduação.

Não levando em consideração as pesquisas sobre a importância da formação inicial e continuada para a docência na instituição superior nacional ou mesmo internacional, a formação docente para o ensino superior ainda fica a cargo de iniciativas individuais e institucionais esparsas.

Ultimamente, segundo Baroni (2007), o Ensino Superior tem passado por várias mudanças, mas a principal delas é ter ampliado a acessibilidade. Antes o estudo era reservado somente à nata da sociedade, hoje já atende grande parte da classe média e com os incentivos federais, como o Programa Universidade para Todos - ProUni, o Financiamento Estudantil - FIES e até mesmo o regime de cotas, tem levado aos brasileiros de baixa remuneração a ter a oportunidade de cursar a universidade.

Outro fator que auxiliou o acesso ao Ensino Superior, menciona Baroni (2008) foi a criação da Educação à Distância - EAD. O crescimento da instituição alcançou entre 2004 e 2007, cerca de 200\%. Em 2004 com a implantação do modelo o número de estudantes matriculados era de 300 mil. Em 2007 já era de 970 mil mesmo com a demora na implantação desse modelo, pois na Inglaterra essa modalidade de ensino foi implantada no ano 1970.

A expansão das instituições de Ensino Superior também foi acelerada pela presença das universidades privadas, hoje representando mais de $70 \%$ do total das universidades. Segundo o professor da Universidade do Estado de São Paulo - UNESP, Dr. Palma Filho até a década de 60 o ensino superior era público. $O$ ensino Superior particular era isolado e dominado pelas Pontifícias Universidades Católicas - PUCs. Durante a ditadura militar ocorreu a

12 Provão é como se denomina o Exame Nacional de cursos de graduação, criado pela lei 9.131/95. O exame tem por objetivo mensurar os processos de decisão e formulação de ações voltada para a melhoria dos cursos de graduação. 
proliferação das universidades particulares, esclarece Baroni (2008). Dobry Pronsato $(2008$, p. 63) comenta em seu doutorado a seguinte situação:

\begin{abstract}
"Grande parte das instituições desse nível tinha origem em antigas escolas de propriedade familiar, muitas vezes de admissão, depois ensino primário e ginasial, que passaram a atuar no ensino superior mantendo a sua tradição do conhecimento existente sem se preocupar com a pesquisa ou 0 trabalho de produção desse conhecimento".
\end{abstract}

A inversão histórica, para o reitor da Universidade Federal da Bahia - UFBA, antiga Faculdade de Medicina da Bahia e primeira instituição de Ensino Superior Brasileira, Naomar Monteiro de Almeida Filho, também atinge 0 público:

" Os estudantes que cursaram o Ensino Médio em escolas particulares migram para as universidades públicas. Já aqueles que obtiveram o diploma do segundo grau por institutos públicos, por falta de opção, partem para as iniciativas privadas".

Nesse mesmo raciocínio, a colunista do jornal O Estado de S. Paulo declara:

"Os mais ricos estudam em colégios particulares caros. Passam nos vestibulares para as universidades públicas e estudam de graça, isto é, à custa dos impostos pagos pelos brasileiros, ricos e pobres. Os mais pobres estudam em escolas públicas, sempre tratadas como investimentos secundários, mal instaladas, mal equipadas, malcuidadas, com magistério mal pago e sem estímulos. ${ }^{13}$

A expansão das instituições privadas, apesar de importante para o desenvolvimento do sistema educacional, teve seu lado ruim, declara Palma Filho: - Pela limitação dos recursos, grande parte não investe em pesquisas. 0

${ }^{13}$ Cavalcanti, Sandra. "Pobres alunos, brancos e pobres..." no jornal O Estado de S.Paulo, 29/12/2008, p.A2. 
professor acredita que a falta de planejamento da expansão do ensino particular também tenha sido negativa, pois os investimentos foram aplicados em cursos mais baratos, na área de humanas, declara Dobry Pronsato:

E por outro lado, a idéia da universidade grande empresa, onde o saber é considerado mercadoria. (2008, p.75)

Não há equilíbrio nas ofertas das outras diversas áreas, o que causa concentração de mão-de-obra, bem como desemprego em certos segmentos e escassez de profissionais em outros, completa ele. 0 crescimento acelerado das vagas, na opinião de Gilberto Gonçalves Garcia, presidente do Conselho de reitores das Universidades Brasileiras - CRUB também atingiu a qualidade do ensino. As avaliações comprovam relação direta entre 0 aumento da oferta e a perda de qualidade no ensino superior. Isso porque o sistema não consegue acompanhar a velocidade da expansão, com a sucessão da excelência do sistema de ensino, argumenta o presidente do CRUB, e confirma Baroni (2008).

Litto acredita que a queda na qualidade tem a ver com a tentativa de nivelar os cursos com a capacidade dos candidatos. Embora todos os estudantes, independente da classe social a que pertençam, tenham potencial e inteligência, as oportunidades são diferenciadas. E não há dúvida que a formação cultural e educacional da classe financeira na maioria das vezes, acaba sendo superior. Portanto, para atender a todos, o grau de exigência do ensino acabou por se enquadrar ao perfil do novo público, enfatiza o presidente da Associação Brasileira do Ensino à Distância - ABED.

No entanto, as instituições privadas passam por dificuldades reais, opina Abib Salim Cury, presidente da Associação Nacional das Universidades Privadas - ANUP. Ele também menciona alguns exemplos que teriam conseguido vencer esses desafios e alcançariam o padrão de excelência das universidades públicas. - Experiências positivas também são comuns em ambos os segmentos, diz se referindo à Fundação Getúlio Vargas - FGV, às PUCs e ao Mackenzie.

Apesar de todas essas questões, há uma grande contradição no Ensino Superior Brasileiro. Enquanto mais de $80 \%$ dos jovens entre 18 e 24 anos não tem acesso ás universidades, esta área enfrenta problemas relacionados a evasão. Esse fato pode ser comprovado se for verificada a quantidades de nomes presentes nas segundas, terceiras e até quartas chamadas do vestibular, alerta Baroni (2008). 
Trata-se de encarar 0 desafio de garantir o acesso superior a todos os brasileiros com a permanência da qualidade. No intuito de atingir essas metas, explica Palma Filho, torna-se fundamental ampliar os investimentos na educação. Estão entre essas alternativas a ampliação dos cursos noturnos e o aumento da relação aluno e professor.

Mas há quem defenda que a melhoria da qualidade do Ensino Superior não depende exclusivamente de recursos. São pessoas que vêem a educação como um sistema integrado, aonde não há como atuar nos níveis escolares separadamente. A qualidade do setor também está ligada à melhoria do poder aquisitivo do brasileiro.

Talvez por causa desses fatores, ainda predominam na disposição universitária, currículos que são organizados por justaposição de disciplinas e a figura do professor se apresenta como transmissor de conteúdos curriculares, embora, muitas vezes fragmentados, insignificantes para o aluno, para 0 momento histórico, e principalmente para os problemas que a realidade apresenta, completam Anastasiou e Pimenta (2005, p.154).

Entretanto, nota-se que ainda existem vestígios do modelo jesuítico e do modelo francês, impedindo muitas vezes a universidade de exercer seu papel de tornar possível os processos de construção do conhecimento.

Experiências com novas formas de enfrentamento dos quadros teóricos-práticos dos cursos de graduação vêem sendo feitos, ainda que sejam em número reduzido. Elas incluem a construção coletiva de projetos pedagógicos institucionais e de cursos, revisões metodológicas na direção de um processo de construção do conhecimento, evidenciando as atividades de ensino com pesquisa, ensino por projetos, e outros, nos quais professores e alunos assumem o papel de sujeitos parceiros, condutores do processo de tornar a universidade um espaço de construção de cidadania, de resoluções das questões nacionais, de formação profissional qualificada e atualizada.

Porém, essas iniciativas não constituem regra geral, baseado em certo consenso de que a docência no ensino superior não requer nenhuma formação no campo de ensinar. Para exercer seria suficiente o domínio de conhecimentos específicos, pois o que a identifica é a pesquisa e o exercício profissional no campo. Mesmo porque, diz o dito popular quem sabe faz, e quem não sabe ensina, Anastasiou e Pimenta (2005, p.36). Assim sendo 0 professor é aquele que ensina que dispõe os conhecimentos aos alunos. Se eles aprendem ou não, é problema do professor, especialmente dos 
professores universitários que muitas vezes está ali como uma concessão, uma forma de complementar o salário.

No maior número de instituições de ensino superior e universidades predomina certo despreparo de alguns de seus professores, até um desconhecimento científico do que seja o processo de ensino e aprendizagem e embora os professores possuam experiência significativa no exercício de sua profissão em suas áreas específicas, passam a ser responsáveis a partir do momento em que ingressam na sala de aula. 0 programa de ensino está organizado de tal forma que os professores ingressam em departamentos que atuam em cursos já aprovados em que também já estão estabelecidas as disciplinas que ministrarão. Aí recebem ementas prontas com direções a seguir, os principais objetivos e organizam o plano de ensino individualmente ou associados aos professores da mesma disciplina. Não recebe, na maioria das vezes, qualquer orientação sobre processos de planejamento metodológicos e avaliatórios.

Em uma rápida visão, a questão da docência na universidade ultrapassa os processos de sala de aula, o que leva a discutir as finalidades do ensino de graduação e pós-reconhecidos em diferentes países. Ao examinar o panorama internacional, conclui-se que nos meios educativos dos países mais avançados, existe um aumento de preocupação com a formação e 0 desenvolvimento de professores universitários e com as inovações no campo da didática. Um dos motivos dessa preocupação é a expansão da educação no nível superior e, por conseguinte o aumento do número de docentes. Dados da UNESCO demonstram que, no período de 1950 a 1992 o número de professores universitários, saltou de 25 mil para um milhão, isto é, aumentou 40 vezes, informam Anastasiou e Pimenta (2005, p. 38) que no entanto em sua maioria, são professores improvisados, não preparados para desenvolver a função de pesquisadores e sem formação pedagógica (UNESCO Cresalc, 1996). 


\section{I - O ENSI NO SUPERI OR BRASI LEI RO DESDE A DÉCADA DE 1990}

Ultimamente, a mídia tem divulgado resultados apontando que 0 nível de aprendizagem de um aluno do ensino médio é extremamente baixo, mesmo na cidade de São Paulo. Segundo a análise dos avaliadores, muitos alunos não conseguem fazer a simples transformação de uma fração para porcentagem 14. Ao consultar os dados oficiais do PNAD/IBGE (Pesquisa Anual por Amostra de Domicílios 2000) obtêm-se a seguinte informação: o total da população na faixa etária entre 15 e 19 anos é estimado em 18 milhões.15 Desse total, o INEP (Instituto Nacional de Estudos e Pesquisa Nacionais Anísio Teixeira) constatou que apenas $45 \%$ desse total encontravam-se matriculados no Ensino Médio no ano de 2007, ou seja, cerca de oito milhões de alunos (o número real é 8.362.994). ${ }^{16}$

${ }^{14}$ Gilberto Dimenstein em "O País do Faz-de-conta" publicado no Caderno Cotidiano da Folha de S.Paulo, domingo 16/03/2008.

15 A Tabela consultada foi a do Censo Demográfico: população residente, por situação de domicílio e sexo, segundo grupos de idade - Brasil. Disponível em

< http://www.ibge.gov.br/home/estatistica/populacao/censo2000/tabelabrasil111.shtm>. Acessado em 13/10/2008. O número correto é 17.938 .815 milhões de jovens.

16 A Tabela encontra-se disponível no site <http://www.inep.gov.br/imprensa/noticias/censo/escolar/news08_01.htm> Acessado em $13 / 10 / 2008$ 


\begin{tabular}{|c|c|c|c|c|c|c|}
\hline \multirow{2}{*}{$\begin{array}{c}\text { Etapas/ } \\
\text { Modalidades } \\
\text { de Educaçâo } \\
\text { Básica }\end{array}$} & \multicolumn{6}{|c|}{ Matrículas nos anos } \\
\hline & 2004 & 2005 & 2006 & 2007 & \begin{tabular}{|c|} 
Diferença \\
$2006-$ \\
2007
\end{tabular} & $\begin{array}{c}\text { Variação } \\
\% 2006- \\
2007\end{array}$ \\
\hline $\begin{array}{l}\text { Educação } \\
\text { Infantil }\end{array}$ & 6.903 .763 & 7.205 .039 & 7.016 .095 & 6.494 .878 & -521.479 & $-7,43$ \\
\hline $\begin{array}{l}\text { Ensino } \\
\text { Fundamental }\end{array}$ & 34.012 .434 & 33.534 .700 & 33.282 .663 & 32.102 .787 & -1.196 .475 & $-3,59$ \\
\hline Ensino Médio & 9.169 .357 & 9.031 .302 & 8.906 .820 & 8.362 .994 & -546.156 & $-6,13$ \\
\hline EJA & 5.718 .061 & 5.615 .426 & 5.616 .291 & 4.983 .060 & -635.464 & $-11,31$ \\
\hline $\begin{array}{l}\text { Educação } \\
\text { Especial }\end{array}$ & 371.382 & 378.074 & 375.488 & 337.089 & -38.786 & $-10,33$ \\
\hline $\begin{array}{l}\text { Educação } \\
\text { Profissional }\end{array}$ & 676.093 & 707.263 & 744.690 & 688.648 & -56.042 & $-7,53$ \\
\hline TOTAL & 56.851 .090 & 56.471 .804 & 55.942 .047 & 52.969 .456 & $\begin{array}{c}- \\
2.994 .402\end{array}$ & $-5,35$ \\
\hline
\end{tabular}

Tabela 1: população residente, por situação de domicílio e sexo, segundo grupos de idade Brasil. Disponível em <

http://www.ibge.gov.br/home/estatistica/populacao/cens02000/tabelabrasil111.shtm>.

$\mathrm{Na}$ análise da tabela acima nota-se que os 18 milhões da população de jovens em idade de cursar o ensino médio, só cerca de oito milhões estão matriculados. São números que embora devessem apresentar uma taxa de crescimento, vem decrescendo um pouco ano após ano. A porcentagem de variação entre os anos de 2006 e 2007 foi de $6,13 \%$ a menos. Outra fonte relacionada ao Sistema Nacional de Avaliação da Educação-SINAES ${ }^{17}$ informa que 0 corpo discente correspondente a estudantes ingressantes em escolas de nível superior no Estado de São Paulo no ano de 2005 foi de 403.673 alunos. Já os que concluíram a graduação são 221.200 concluintes.

Isto pode gerar a seguinte conclusão: no Brasil, têm-se menos da metade de jovens (45\%) estudando no ensino médio em estabelecimentos públicos ou privados. Desse total só cerca de 400 mil alunos ingressam no estudo superior. Esse fato reflete que apesar do aparente aumento do número de escolas privadas de ensino superior, o número de estudantes ingressantes ainda é extremamente baixo. Ainda têm-se espaço para muito mais vagas, e com o desenvolvimento do país, e decorrente atenção federal para a educação em geral, esse número pode aumentar ainda mais.

${ }^{17}$ Disponível no site <http://sinaes.inep.gov.br/sinaes/>. Acessado em 13/10/2008. 
Esta constatação pode ser realizada em razão do número de propagandas de escolas de graduação privadas que se mostram aparecem diariamente em todos os meios de informação. É um assunto que tomou proporção principalmente nos período dos vestibulares. E como só isto não fosse 0 suficiente, o número de escolas públicas, no caso, as universidades estaduais ou federais não tem oferecido suas instalações e nem vagas suficientes no mesmo índice de crescimento das privadas.

O que se observa é que há determinadas universidades privadas que têm aberto as portas para um contingente significativo de estudantes, nas quais são oferecidos diversos cursos sem competição acirrada entre os alunos. Já que há vagas para todos que procuram, em todos os cursos oferecidos, 0 estudante que manifesta desejo de cursar uma faculdade pode alcançar o seu objetivo em cursar o nível superior. Pode-se dizer que 0 ensino superior está acessível a todos que tenham concluído o ensino médio. Há faculdades em que as vagas são oferecidas por meio de um agendamento marcado à disponibilidade do candidato para fazer a prova de seleção. Já as provas de seleção, parecem facilitar sobremaneira o livre acesso de todos os candidatos ao curso superior nas áreas oferecidas pelas universidades.

\section{II - EXPANSÃO DO ENSI NO PRIVADO}

0 estado de São Paulo possui ${ }^{18} 60$ cursos de graduação em arquitetura e urbanismo regularizados e relacionados na Associação Brasileira de Ensino de Arquitetura e Urbanismo - ABEA. Existem por volta de 180 escolas existentes no país. Na cidade de São Paulo existem pelo menos 12 cursos de graduação. Desses cursos, apenas um público, a Faculdade de Arquitetura e Urbanismo da Universidade de São Paulo - FAUUSP com 150 vagas, todas as outras vagas estão disponíveis em faculdades privadas (aproximadamente 600 vagas).

Ainda relacionando dados da $A B E A$, o número de cursos de graduação passou de 72 em 1994 para 152 em 2003, informam Lara e Marques (2003, p.94). Destes últimos, apenas $22 \%$ são cursos oferecidos por instituições públicas, sendo a grande maioria, $78 \%$ do total instituições particulares. Outro dado interessante é que no ano de 2001, por exemplo, 42.018 alunos se matricularam em cursos de arquitetura e urbanismo, sendo

${ }^{18}$ Disponível no site: < http://www.abea-arq.org.br/cursos sp.html > . Acessado em 13/10/2008. 
que $\mathbf{1 5 . 3 7 9}$ (36.6\%) em novas vagas (ingressantes), restando 26.639 alunos matriculados. Já em 2002, o número de formandos foi de apenas 6.189, demonstrando que a grande maioria das matrículas existentes era de alunos ingressantes. Observa-se que a cada novo ano a quantidade de arquitetos novos no mercado de trabalho tem sido sistematicamente elevada, como explicam Lara e Marques (2003, p.95).

Os dados da Tabela $2{ }^{19}$ mostram que a concentração de alunos na Região Sudeste é mais da metade do total de formandos no Brasil.

\begin{tabular}{|l|l|l|l|l|}
\hline REGIÕES & CURSOS (2003) & & & \\
\hline & TOTAL & PÚBLICOS & PRIVADOS & $\begin{array}{l}\text { NÚMERO DER } \\
\text { FORMANDOS } \\
(2002)\end{array}$ \\
\hline SUDESTE & $\mathbf{7 6}$ & $\mathbf{1 2}$ & $\mathbf{6 4}$ & $\mathbf{3 . 4 5 4}$ \\
\hline SUL & 37 & 7 & 30 & 1.341 \\
\hline NORDESTE & 20 & 9 & 11 & 841 \\
\hline NORTE & 6 & 2 & 4 & 230 \\
\hline CENTRO-OESTE & 13 & 5 & 8 & 323 \\
\hline TOTAL & $\mathbf{1 5 2}$ & $\mathbf{3 5}$ & $\mathbf{1 1 7}$ & $\mathbf{6 . 1 8 9}$ \\
\hline
\end{tabular}

Tabela 2 - Cursos de Arquitetura e Urbanismo ofertados por região (2003).

Fonte dos dados: ABEA, 2003

Onde deveria surgir o debate sobre a formação profissional do curso de arquiteto, além de alguns seminários e congressos? Não seria dentro da universidade que tanto forma arquitetos, como professores, mestres e doutores? A Faculdade de Arquitetura e Urbanismo da Universidade de São Paulo- FAUUSP não poderia assumir esse papel?

Segundo dados obtidos na FAUUSP ${ }^{20}$ em 1972 foi criado o curso de mestrado, um dos pioneiros da América Latina, e em 1980 o curso de doutorado, que permaneceu como único doutorado no país até 1998. Levantamento realizado no primeiro semestre do ano de 2004 dá dimensão do Programa de Pós-Graduação da Faculdade de Arquitetura e Urbanismo da Universidade de São Paulo: estavam credenciados 120 orientadores, 298

19 Dados extraídos de Lara e Marques (2003, p.)

${ }^{20}$ Disponível no site: $<$ http://www.usp.br/fau/ensino/pos/index.html $>$. Acesso disponível em 13/03/2008. 
alunos de Mestrados, 286 alunos de Doutorado e 351 alunos especiais, inscritos nas 34 disciplinas oferecidas naquele semestre. Contabilizando, portanto, a extensão do Programa de Pós-Graduação, verifica-se que a FAUUSP foi 0 berço de muitos mestrandos e doutorandos de diversos estados brasileiros. Seguindo esta tradição, e expostos os atuais números referentes à consolidação da pós-graduação fica clara a sugestão de uma postura dessa instituição.

Os números da pós-graduação vem reforçar a política nacional de expansão do ensino superior que o MEC vem implementando no país, na afirmação de Veloso e Elali (2003, p.95). No entanto, ao observar a Tabela 20 que se verifica é o aumento dos institutos de educação superior privados.

Ainda segundo Veloso e Eulali (2003, p.96) esses dados indicam que a competição entre arquitetos recém formados tornou-se mais competitiva, exigindo melhor qualificação para quem for enfrentar o mercado de trabalho. $\mathrm{E}$ este tipo de capacitação está ao alcance de quem procurar cursos de pósgraduação lato sensu e stricto sensu.

Outro assunto bastante relevante é a busca da profissão de docentes da parte dos arquitetos. Fatores como dificuldade de colocação do mercado de trabalho ou mesmo a baixa remuneração no início da vida profissional faz com que muitos arquitetos se transformem em docentes, relatam Veloso e Elali (2003. p.96):

\footnotetext{
[...] "reduzido preparo para o exercício da docência, a falta de vínculos estáveis e a alta rotatividade de professores nas instituições (principalmente nos novos cursos), são considerados prejudiciais para a qualidade do ensino superior".
}

$\mathrm{Na}$ tentativa de tentar diminuir os problemas citados anteriormente, o MEC tem incentivado as instituições a buscarem professores melhores preparados, para subir a nota de avaliação do corpo docente de cada instituição. Um exemplo de tal procedimento é, de acordo com Veloso e Elali, 2003, p.96), o concurso para ingresso do quadro docente nas universidades públicas, onde necessariamente 0 candidato deve ser titulado como professordoutor. Em geral, se reconhece que para dedicar-se a carreira docente é preciso percorrer os caminhos da pós-graduação e da pesquisa científica. 
Nota-se que há uma certa dificuldade em publicar pesquisas aplicadas ao projeto arquitetônico. Os organizadores Lara e Marques (2003, p.8) do I Seminário sobre Ensino e Pesquisa em Projeto de Arquitetura, promovido pelo Programa de Pós Graduação em Arquitetura e Urbanismo da Universidade Federal do Rio Grande do Norte - PPGAU/UFRN realizado em 2003 advertiam que no Brasil ainda se projeta, se ensina e se discute o projeto da mesma maneira que há vinte anos atrás, afirmando ainda que 0 ensino superior de arquitetura envolve a questão da carência de pesquisa e o reduzido preparo para o exercício da docência. Segundo as Diretrizes Curriculares Nacionais dos cursos de graduação em Arquitetura e Urbanismo contidas na Resolução CNE/CES no. 06 de 02/02/2006 ${ }^{21}$, o conteúdo das disciplinas de graduação é genericamente indicado. 0 documento reúne conceitos defendidos de forma consorciada pela ABEA, Instituições de Ensino da área, Comissão de Educação do Conselho Federal de Engenharia, Arquitetura e Agronomia, CONFEA e entidades nacionais da categoria.

Em geral, nas Faculdades de Arquitetura e Urbanismo, o primeiro ano ,em geral, é constituído de disciplinas que possam suprir falhas no Ensino Médio. São disciplinas fundamentadas em português, matemática, física, e às vezes, técnicas de redação, elaboração de análises e monografias, leitura de gráficos, realização de seminários, incentivo à leitura, entre outros. Serão suficientes as atuais exigências do MEC no sentido de fomentar um ensino superior de qualidade, uma vez que devido à alta demanda, atualmente, o MEC exige algumas indicações quanto ao número de professores, salas de laboratórios especializados e um número mínimo de títulos na biblioteca.

Refletindo a demanda crescente da sociedade por arquitetos e urbanistas e a política atual do MEC de ampliar o número de matrículas do ensino superior, a área de arquitetura e urbanismo vem crescendo significativamente, contando hoje com aproximadamente 40.000 alunos e cerca de 5.000 docentes ${ }^{22}$. Do total de cursos em funcionamento, cerca de 180 deles já estão devidamente reconhecidos pelo MEC e são responsáveis pela educação de cerca de 6.000 profissionais arquitetos e urbanistas que ingressam, por ano, no diversificado mercado de trabalho brasileiro.

No entanto, o debate sobre a qualidade da formação não é sequer citado dentro das entidades de ensino, e tal processo tem sido legitimado. Talvez por causa desses fatores, ainda predominam na disposição

\footnotetext{
${ }^{21}$ Disponível no site: http://www.abea-arq.org.br/diretrizes.html. Acessado em 13/10/2008.

22 Disponível no site: < http://www.abea-arq.org.br/informacoes.html>. Acesso disponível em 13/03/2008.
} 
universitária currículos que são organizados por justaposição de disciplinas e a figura do docente se apresenta como transmissor de conteúdos curriculares, embora, muitas vezes fragmentados, insignificantes para o aluno, para 0 momento histórico, e principalmente para os problemas que a realidade apresenta, completam Anastasiou e Pimenta (2005, p.154).

Entretanto, nota-se que ainda existem vestígios do modelo jesuítico e do modelo francês, impedindo muitas vezes a universidade de exercer seu papel de tornar possível os processos de construção do conhecimento.

Experiências com novas formas de enfrentamento dos quadros teóricos-práticos dos cursos de graduação vêem sendo feitos, ainda que sejam em número reduzido. Elas incluem a construção coletiva de projetos pedagógicos institucionais e de cursos, revisões metodológicas na direção de um processo de construção do conhecimento, evidenciando as atividades de ensino com pesquisa, ensino por projetos, e outros, nos quais professores e alunos assumem o papel de sujeitos parceiros, condutores do processo de tornar a universidade um espaço de construção da cidadania, de resoluções das questões nacionais, de formação profissional qualificada e atualizada.

No entanto, essas iniciativas não constituem regra geral, baseado em certo consenso de que a docência no ensino superior não requer nenhuma formação na área de ensinar. Para o exercício da docência seria suficiente 0 domínio de conhecimentos específicos, pois o que a identifica é a pesquisa e o exercício profissional na área. Mesmo porque, diz o dito popular quem sabe faz, e quem não sabe ensina, Anastasiou e Pimenta (2005, p.36). 0 docente é aquele que ensina e dispõe os conhecimentos transmissíveis aos estudantes.

No maior número de instituições de ensino superior $e$ universidades predomina certa falta de experiência de alguns docentes, até um desconhecimento científico do que seja o processo de ensino e aprendizagem e embora, os professores possuam experiência no exercício de sua profissão em suas áreas específicas, passam a ser responsáveis a partir do momento em que ingressam na sala de aula, o que de um lado pode transmitir o conhecimento advindo de sua prática, e não da pesquisa científica. 0 programa de ensino está organizado de tal forma que os professores ingressam em departamentos que atuam em cursos já aprovados em que também já estão estabelecidas as disciplinas que ministrarão. Recebem ementas prontas com direções a seguir, os principais objetivos e organizam o plano de ensino individualmente ou associados aos professores da mesma disciplina. Não recebe, na maioria das 
vezes, qualquer orientação sobre processos de planejamento metodológicos e avaliatórios.

Não obstante, a questão da docência na universidade ultrapassa os processos da sala de aula, o que leva a se discutir as finalidades do ensino de graduação e pós-reconhecidos em diferentes países. Ao examinar 0 panorama internacional, conclui-se que nos meios educativos dos países mais avançados, existe um aumento de preocupação com a formação e 0 desenvolvimento de professores universitários e com as inovações no campo da didática. Um dos motivos dessa preocupação é a expansão da educação no nível superior e, por conseguinte o aumento do número de docentes. Dados da UNESCO demonstram que, no período de 1950 a 1992 o número de professores universitários, saltou de 25 mil para um milhão, i. e., aumentou 40 vezes, explicam Anastasiou e Pimenta (2005, p. 38). No entanto, em sua maioria, são professores improvisados, não preparados para desenvolver a função de pesquisadores e sem formação pedagógica UNESCO/ Cresalc, 1996).

O MEC tem incentivado as instituições a buscarem professores mais capacitados para o exercício da profissão, o que se traduz através do Índice de Qualidade Docente (IQD), um dos elementos utilizados para avaliar escolas. Nas universidades federais, por exemplo, os concursos solicitam que os candidatos apresentem o título de doutor, o que corresponde à categoria de professor adjunto. Não havendo preenchimento dessas vagas, são abertas inscrições para assistentes com títulos de mestres e, apenas em último caso para auxiliares graduados.

Outro fator é a preocupação com a qualidade dos resultados do ensino superior com a preparação no campo específico e no campo pedagógico de seus docentes. Anastasiou e Pimenta (2005, p.38) consideram que 0 documento da Conferência Internacional sobre Ensino Superior - uma perspectiva docente, Paris 1997, promovida pela organização Sindical Internacional da Educação expressa preocupações com temas ausentes na docência universitária, como:

- A qualidade da educação, a educação a distância e as novas tecnologias;

- A gestão e o controle do ensino superior;

- O financiamento do ensino e da pesquisa;

- O mercado de trabalho e a sociedade;

- A autonomia e as responsabilidades das instituições,

- Os direitos e liberdades dos professores do ensino superior.

As áreas de atuação do professor universitário identificadas por Anastasiou e Pimenta (2005. p.141) abrangem uma variedade de tipos de 
instituições de ensino superior onde ele pode exercer a sua profissão em uma das modalidades de instituições de ensino superior, a saber:

- Universidade: com autonomia didática, administrativa e financeira, que se caracteriza por desenvolver o ensino, extensão e pesquisa;

- Centro universitário: atua em uma ou mais áreas com autonomia para determinação de cursos, e sua extensão, abrir ou fechar cursos, vagas de graduação e ensino;

- Institutos ou escolas superiores atuam em áreas específicas do conhecimento podem ou não, além do ensino, fazer pesquisa. Dependem do Conselho Nacional de Educação para a criação de novos cursos,

- Faculdades Integradas reúnem instituições de diferentes áreas do conhecimento e podem também oferecer extensão e pesquisa.

Qualquer que seja a instituição que o professor atue, será exigido dele uma atividade comum: a docência. Embora o sistema não se preocupe com a profissionalização dos docentes e não estabeleça princípios e diretrizes para a profissionalização dos docentes do ensino superior, realiza verificações sobre a docência: resultados dos alunos no provão, índices de professores com 0 mestrado e o doutorado e avaliação para definir a qualidade. Assim o Estado mesmo desconhecendo as funções da universidade como instituição social, estabelece as formas para profissionalizar e avalia os professores.

\section{III- DOCÊNCI A E DI DÁTI CA?}

[...] "o professor universitário aprende a sê-lo mediante um processo de socialização em parte intuitiva, autodidata ou [...] seguindo a rotina dos outros. Tudo isso se explica, sem dúvida, devido à inexistência de uma formação específica como professor universitário. Nesse processo, joga um papel mais ou menos importante na sua própria experiência como aluno, o modelo de ensino que predomina no sistema universitário e as reações de seus alunos embora não há que se descartar a capacidade autodidata do professorado. Mas ela é auto- 
suficiente." Benedito (1995 apud ANASTASIOU e PIMENTA, 2005, p.36)

Ao abordar o tema do professor universitário, observa-se um fato: de que forma profissionais de áreas diversas, que não possuem nenhuma formação no campo da Pedagogia, tornam-se docentes no magistério superior?

Essa reflexão, trazida a esta tese sob o ponto de vista de Bazzo (2007) é parte importante da análise que pode ser feita a respeito da formação dos professores universitários.

De que modo os professores do ensino superior se identificam profissionalmente? Um arquiteto ou um engenheiro, por exemplo, que leciona no ensino superior, ao preencher uma ficha de identificação qualquer como se identificaria profissionalmente? Provavelmente a forma de identificação mais usual seria a de arquiteto ou engenheiro seguido das palavras de professor universitário.

Esta questão feita pelos autores Anastasiou e Pimenta (2005, p.35) demonstram a valorização social do título de docente no ensino superior quando o profissional exerce também as suas atividades como profissionais autônomos.

Importantes estudos realizados têm esclarecido que não bastam aos professores deterem sólido conhecimento de sua área específica, ou mesmo terem passado por cursos de pós-graduação stricto sensu, para ter a sua profissionalidade docente reconhecida.

Tendo como base, a reunião dos depoimentos de vários professores universitários, a autora Bazzo (2007) ao lhes perguntar sobre como aprenderem a serem professores, a maioria das respostas foi de forma empírica, quase sempre por imitação ou por ensaio e erro.

Os professores alegavam o fato de que não tiveram formação específica para o magistério superior, embora tenham feito cursos de pós-graduação (mestrado ou doutorado) e que aprenderam a fazer, fazendo:

"Geralmente os professores ingressam em departamentos que atuam em cursos aprovados, em que já estão estabelecidas as disciplinas que ministrarão. Aí recebem ementas prontas, planejam individual e solitariamente, e é nesta condição individual e solitariamente - que devem se responsabilizar pela docência exercida". Anastasiou e Pimenta (2005, p.37) 
Nota-se que os professores universitários, em geral, não recebem orientação sobre processos de planejamento, relatórios metodológicos ou avaliatórios. Não há a exigência de relatórios sistemáticos, momento em que o docente poderia refletir sobre a própria ação de ensinar, como acontece nos processos de pesquisa, relatam Anastasiou e Pimenta (2005, p. 108):

\begin{abstract}
"Assim, o professor fica entregue a própria sorte. Nesse contexto, não é de estranhar a permanência de uma relação entre o professor, aluno e conhecimento na sala de aula de modo secularmente superado, tradicional, jesuítico, cientificamente ultrapassado".
\end{abstract}

Alguns professores relataram a Bazzo (2007) que aprenderam a sobreviver na área docente imitando professores que tinham tido e que valia pena tentar imitar". Não era difícil para o professor universitário admitir que as aulas que conseguiam programar eram a imagem das aulas que haviam tido na graduação. Como não receberam formação pedagógica, foram aprendendo a docência pelo convívio com os pares e pela repetição.

Quando perguntados se incluíam inovações, alguns docentes responderam que quase ou nunca modificavam ou inovavam o conteúdo de suas aulas e que iam tentando melhorar aos poucos, a cada novo semestre, a cada nova turma. Contudo, manifestavam que se tratava de uma iniciativa solitária e empírica. Ao serem perguntados se caso houvesse uma formação para a prática docente, os professores assumem que assim sofreriam e se exporiam menos, segundo, afirma Bazzo (2007).

Sendo assim há um certo consenso de que a docência no ensino superior não requer formação no campo de ensinar. Seria suficiente o domínio de conhecimentos específicos, pois o que a identifica é a pesquisa e o exercício funcional no campo. Mas, aproveitando a questão, como se define a profissão do professor universitário? Qual a sua abrangência e influência na sociedade? 0 que é profissão docente?

Inicialmente, a profissão docente é uma prática educativa, uma forma de intervir na realidade social mediante a Educação, informam Anastasiou e Pimenta (2005, p.179). Para um melhor entendimento dos significados de prática docente como prática educativa, foi estabelecida a diferença entre os termos prática e ação. A prática compreende as formas de 
educar que pode ocorrer nos mais diferentes contextos institucionalizados, visando a cultura e as

tradição das instituições. A tradição seria o próprio conteúdo e o método de educação usado. A ação se refere aos docentes, sua maneira de agir e pensar, seus valores e opções, seus desejos e seu conhecimento. Ela se realiza nas práticas institucionais, nas quais os sujeitos se encontram sendo por esta determinada e nelas determinando, esclarecem Anastasiou e Pimenta (2005, p.179).

A prática educativa pode ser definida com a dimensão da técnica de ensinar envolvendo aspectos como inovações curriculares, materiais didáticos, controle de aula, competência e habilidade do professor, acrescentam Anastasiou e Pimenta (2005, p.180). Seu campo de atuações é a instituição de nível superior, cuja finalidade é o exercício permanente da crítica, que se acha apoiada na pesquisa, no ensino e na extensão. Estes fatores levam a produção do conhecimento por meio da problematização dos conhecimentos históricos produzidos, de seus resultados na construção da sociedade humana e seus desafios. Por sua vez, são produzidos e identificados também pelo professor universitário, as análises que se realizam no próprio processo de ensinar, e na experimentação e análise dos projetos de extensão, mediante as relações estabelecidas entre os sujeitos e os objetos de conhecimento.

Estes temas se tornam preocupantes quanto à preparação do docente universitário, especialmente, na área da educação, que experimenta uma mudança constante. Supõe-se que o profissional deva ter o domínio de seu campo específico de conhecimentos e antes de qualquer coisa, qual o significado que estes conhecimentos têm para si próprio. Além disso, quais os significados destes conhecimentos na sociedade contemporânea, a diferença entre conhecimentos e informações, conhecimentos e poder, qual o papel do conhecimento no mundo do trabalho, qual relação entre ciência e produção material, entre ciência e sociedade informática: como os conhecimentos históricos, matemáticos, das ciências sociais, da educação física, dos conhecimentos biológicos e geográficos, das artes cênicas, plásticas e musicais.

Assim, o ensino na universidade, pode se constituir em um processo de busca, de construção da crítica ao conhecimento produzido, de seu papel realizado, de sua participação na construção da sociedade.

Anastasiou e Pimenta (2005, p.164) citam algumas atribuições que enfatizam o ensino para: 
- Pressupor o domínio de um conjunto de conhecimentos, métodos e técnicas científicos, que assegurem o domínio científico e profissional do campo específico e devem ser ensinados com crítica, enfim estimular o desenvolvimento das habilidades da pesquisa;

- Conduzir a uma progressiva autonomia do aluno na procura de conhecimento;

- Considerar o processo de ensinar/aprender como atividade integrada à investigação;

- Fomentar a capacidade de reflexão;

- Trocar a simples transmissão de conteúdos por um processo de investigação do conhecimento;

- Integrar, vertical e horizontalmente, a atividade de investigação à atividade de ensinar do professor, motivando o trabalho em equipe;

- Criar e recriar situações de aprendizagem;

- Valorizar a avaliação diagnóstica e compreensiva da atividade mais do que a avaliação como controle,

- Conhecer o universo cultural e de conhecimentos dos alunos e desenvolver, com base nele, processos de ensino e aprendizagem interativos e participativos.

Enfim, as atribuições de ensinar na universidade exigem do professor universitário uma atuação como profissional, crítico e competente no âmbito de sua disciplina, capacitado a exercer a docência e realizar atividades de investigação. As autoras salientam em seu livro que podem ser identificados, no mundo atual, três aspectos que impulsionam 0 desenvolvimento profissional do professor universitário: 
- A transformação da sociedade e de seus valores e de suas formas de organização e trabalho;

- O avanço da ciência nas últimas décadas,

- A consolidação de uma ciência da Educação permitindo a todos o conhecimento no campo da Pedagogia.

Neste sentido, [...] a constituição da profissão docente precisa centrar-se no que efetivamente pode constituí-la na sua singularidade e não apenas na comparação com outras profissões, Guimarães (2001 apud ANASTASIOU e PIMENTA, 2005, p. 118).

As autoras tentam citar quais as principais situações e condições que cercam a profissão do professor universitário. São elas:

- Condições de trabalho no ensino superior;

- Profissão de professor e condição de trabalho;

- Dos saberes à competência, reduzindo a docência a técnicas.

1) Formas de Organização e Condições de Trabalho:

A profissionalização deve ser uma retórica necessária somente para quem a faz, porque, efetivamente, como está, está bom. Isto quer dizer, nada precisa ser alterado, porque é natural que não se necessite formar e profissionalizar professores, uma vez que eles já nasceram sabendo, avisam Anastasiou e Pimenta (2005, p. 118). Porém, é preciso reconhecer na profissão docente sua especialidade diferente de outras profissões: plena de saberes próprio, construídos também em situação, e sua dimensão ética nesse sentido [...] a constituição da profissão docente precisa centrar-se no que efetivamente, pode constituí-la na sua singularidade e não apenas na comparação com outras profissões.

As condições de trabalho dos professores nas instituições de ensino superior são diferentes quanto à forma de ingresso, vínculo, à jornada de trabalho e aos seus compromissos. 
No caso de instituições públicas, o ingresso se dá sempre por concurso, mesmo para contratar o professor substituto. Se o professor for efetivo, este passa por um período de estágio probatório e no final sua efetivação poderá ser confirmada ou não mediante um processo de avaliação por seus pares.

Nas instituições particulares, o ingresso se dá por concurso ou por convite e o contrato é regido pela função da docência. Ainda ocorre a contratação por bloco de aulas reunidas em períodos específicos dos cursos, ficando o professor vinculado à instituição apenas por aquele período não havendo compromissos institucionais nem direitos trabalhistas além daqueles do contrato temporário.

2) Profissão e Condições de Trabalho:

No caso de professores de nível superior, as oportunidades de emprego vêm aumentando, principalmente se considerarmos as instituições particulares de ensino, se expandindo em todo o território nacional. Esse aumento de números de empregos não está associado a processos de profissionalização para o professor universitário. As exigências para a docência no nível superior se acham associadas apenas à formação da área específica. Além disso, se for levado em conta que, freqüentemente a atividade docente é assumida pelo profissional universitário como mais uma atividade para a obtenção de renda, e não como profissão de escolha, os próprios docentes não valorizam uma formação profissional relatam Anastasiou e Pimenta (2005, p. 129). Todavia, quanto aos professores, já estão surgindo novas formas de emprego como trabalho autônomo e terceirizado (por exemplo, professores de educação física que são contratados em academias).

Vale dizer que surgem também outros empregos sob a forma de monitoria, que em algumas universidades é realizado em substituição ao trabalho do docente, alterando não só sua identidade quanto os seus saberes e seu significado destes na formação dos alunos, porque confere ao monitor um papel de auxiliar técnico.

Continuando, em países como Espanha e Portugal, após longos períodos de ditadura, adentraram em processo de democratização social e política, identifica-se o reconhecimento das instituições educativas e dos professores como participantes fundamentais nesse processo, diferente do que vem ocorrendo no Brasil. 
Tal reconhecimento levou esses países a fazer significativas alterações nos seus sistemas de ensino, explicam Anastasiou e Pimenta (2005, p. 130). 0 início se deu elevando a formação dos professores da escola básica para o nível superior (em processo) e assim, investindo na formação inicial e contínua e no desenvolvimento das instituições escolares, elevando o estatuto de profissionalização dos professores e incluindo a reestruturação do quadro de carreira, das condições de trabalho e dos salários. Nos anos 90 , a problemática volta-se para a questão da docência (e dos docentes) no ensino superior.

A atuação dos professores reproduz-se na valorização do seu pensar, do seu sentir, de suas crenças e de seus valores como aspectos importantes para compreender o seu fazer, não somente em sala de aula, mas também executando, elaborando, definindo os currículos. Surge assim, a importância da realização de pesquisas para que se possa compreender realmente o exercício da docência, de suas profissionalidades, quais os processos de construção de sua identidade docente, o desenvolvimento de sua profissionalização, finalmente as suas condições de trabalho, de status, de liderança.

Os professores, continuam ainda Anastasiou e Pimenta (2005, p 188), devem modelar um tipo de profissionalismo, no qual:

- Promovam um aprendizado cognitivo profundo;

- Sejam comprometidas com uma atividade profissional contínua;

- Aprendam a ensinar de modo diferente de como aprenderam;

- Trabalhem e aprendam com seus pares;

- Desenvolvam a capacidade para arriscar e pesquisar,

- Construam organizações de aprendizagem nas escolas.

Para serem considerados elementos de resistência dessa sociedade devem: 
- Promover a aprendizagem e o comprometimento social e emocional;

- Comprometer-se com o desenvolvimento contínuo tanto do aspecto profissional quanto do pessoal;

- Aprender a se relacionar, construindo ligações duradouras com as pessoas,

- Trabalhar e aprender em grupos cooperativos.

Mas já podemos contar com inúmeras iniciativas na área da formação dos professores que apontam para melhorias na profissionalização docente e na aprendizagem dos alunos, relacionadas com a pesquisa da prática e a exploração dos saberes da experiência.

Atualmente, percebe-se que existe um avanço do desempenho pedagógico, principalmente quando 0 docente sistematiza e desenvolve habilidades próprias ao método de pesquisa. Isto é, estimular o método de ensinar com pesquisa e repassar a importância de pesquisar e ensinar.

Anastasiou e Alves (2007, p.191) relatam no que consiste os dois métodos, o de ensino e o de pesquisa, e os resultados dessas ações comuns para 0 docente. Em seguida, há uma análise dos componentes presentes nos dois métodos em relação ao ensino e a pesquisa.

Os componentes são, contam Anastasiou e Alves (2007, p. 188):

- Os sujeitos envolvidos;

- 0 tempo;

- Os resultados;

- O método,

- 0 reconhecimento.

$\mathrm{Na}$ atividade de pesquisar, os elementos envolvidos são: 
- Os sujeitos envolvidos: o trabalho pode ser realizado individualmente ou em grupo (mais freqüente), mas haverá necessariamente parceria do orientador ao longo das etapas;

- O tempo: é habitualmente previsto em blocos, mas dependendo do projeto do nível, pode comportar alterações justificadas, imprevistos, novos problemas e questões a superar, admitindo certa flexibilidade;

- Os resultados: é o conhecimento que se obtém ao término da pesquisa sobre o problema. Este conhecimento pode confirmar a terra existente ou levar a revisão parcial ou total do referencial científico estudado. O conhecimento obtido constitui síntese que pode preceder novas sínteses. Esse novo conhecimento, possibilita ou não novas teorias científicas,

- Os métodos: ele é definido de acordo com o problema a ser estudado. Normalmente trabalha-se com métodos já existentes, testados e aceitos pela comunidade científica. Por exemplo, pesquisa sobre documentos de arquitetura, concebidas com a ajuda de operações analógicas (desenhos, figuras, modelos, maquetes). Ao longo do processo, recebe-se assessoria do orientador ou do grupo de pesquisa do qual se participa.

$\mathrm{Na}$ atividade de ensinar, os elementos envolvidos são:

- Os sujeitos envolvidos: o professor se confronta com outros sujeitos. Inicialmente com seus pares institucionais: chefias de departamento, coordenadores, colegas docentes. Nesse caso, deverá trabalhar colegiadamente, em torno de um projeto institucional comum a ser realizado no plano do curso específico em que atuará como docente.

Deverá atender as decisões que serão definidas com relação à sua disciplina e tomará decisões sobre as ações docentes em equipe, deixar-se conhecer profissionalmente. Saber ouvir, ponderar, decidir.

Além da equipe docente, o professor confronta-se com os estudantes, que constitui a razão de ser de sua profissão. Esses alunos são personagens históricos e com características próprias. Interagem com os docentes por períodos determinados (semestrais ou anuais). Não existe 
garantia de um processo que funcionou bem com um grupo vai obter êxito com outro.

- Quanto ao tempo, no ensino, é diferente do tempo na pesquisa. 0 processo de adquirir novos conhecimentos tem que se adequar ao semestre (4 meses de aula) ou ao ano (mais ou menos oito meses) para encerramento do programa previsto. Não há flexibilidade, a adequação temporal constitui desafios;

- Quanto aos conhecimentos: trabalha-se com conteúdos já existentes, sistematizados, elaborados e organizados - no sentido de se tornarem próprias aos alunos - com a orientação do professor. Os conhecimentos devem ser traduzidos pelos sujeitos do processo, professor e alunos, de acordo com a disciplina, do programa de aprendizagem e do curso como um todo e se efetivou ao ocorrer a apropriação dos conteúdos;

- Quanto aos resultados: o ensino deve propiciar novos caminhos e novas sínteses, por parte dos professores e também dos alunos ampliando dessa forma a herança cultural;

- Quanto ao método: o ensino depende inicialmente da visão de ciência, de conhecimento e de saber escolar do professor. Se ele assume a disciplina que leciona como fim em si mesma, adotará um método de transmissão e reprodução do conhecimento; Sob o ponto de vista da ciência, o conhecimento é tomado como neutro, distanciado de seu processo de produção, definitivo e verdadeiro. Desse modo, o método deve ser construído em parceria e, embora, se trate de responsabilidade compartilhada, inclui ações diferenciadas de professores e alunos. Por conseguinte, o método de ensino ou 0

- ato de ensinar, por sua complexidade e temporalidade, exige um processo de reflexão sistemática, portanto, de pesquisa por parte daqueles que pretendem efetivá-lo com competência e seriedade. 
A diferenciação entre profissionalidade e empregabilidade permite maior clareza no processo de construção dos professores como categoria profissional. A empregabilidade caracteriza-se pela capacidade da pessoa de executar atividades requeridas pelo modelo de desenvolvimento. A profissionalidade envolve ter capacidade da pessoa de executar atividades requeridas pelo modelo de desenvolvimento. A profissionalidade envolve ter capacidade para conceber e implementar novas alternativas, diante da crise e dos problemas da sociedade:

“Ao pensar a docência do $3^{0}$ grau, não por isso deixar de destacar a importância fundamental da pesquisa [...]. 0 professor deve ser capaz de gerar conhecimento próprio, para poder ensinar ao aluno qualidade básica da universidade que é a criação científica", conta Cappelletti (1992 apud MARQUES e LARA, 2005, p.97)

Quanto à construção da identidade docente, segundo Nóvoa (1992 apud ANASTASIOU e PIMENTA, p. 112), três processos são essenciais:

- O desenvolvimento pessoal que se refere aos processos da vida do professor;

- O desenvolvimento profissional que se refere aos aspectos da profissionalização,

- O desenvolvimento institucional que refere aos investimentos da instituição para a consecução dos seus objetivos educacionais.

Contudo, neste sentido [...] a constituição da profissão docente precisa centrar-se no que efetivamente pode constituí-la na sua singularidade e não apenas na comparação com outras profissões, informa Gumarães (2001 apud ANASTASIOU e PIMENTA 2005, p. 118).

Investir na docência universitária e na defesa de um espaço específico como o local de formação dos professores em geral, significa um movimento de valorização da educação de uma qualidade de mais alta classe para todos.

3) Dos Saberes à Competência - reduzindo a docência a técnicas: 
Nos dias atuais, o que se constata é o refinamento dos mecanismos de controle existentes, sobre as atividades de professor preestabelecendo-as em inúmeras competências. 0 conceito de competência está substituindo 0 de saberes e 0 de conhecimento, quando for o caso de educação e a qualificação, quando for o caso de trabalho. Essa substituição expropria o professor de sua condição de sujeito do seu conhecimento.

Por conseguinte, 0 termo competência, abertos a várias interpretações, é mais adequado do que o termo de saberes e qualificação para uma desvalorização profissional dos trabalhadores em geral, inclusive dos professores.

Substituir o termo competência pelo de saberes profissionais, desloca a identidade do trabalhador para o seu local de trabalho, seu "posto de trabalho".

$\mathrm{Na}$ realidade, desta forma, difícil haver reconhecimento de que os professores não se limitam apenas a executar currículos, senão os que elaboram, os definem e os reinterpretam com base no que pensam, crêem, valorizam, conforme as conclusões das pesquisas?

Mas, o termo competência também significa teoria e prática para fazer algo, conhecimento em situação - necessário para qualquer trabalhador, inclusive para 0 professor. Mas ter competência é diferente de ter conhecimento e informação sobre o trabalho, sobre o que se faz. Conhecer implica consciência ampla das raízes, dos desdobramentos e implicações do que se faz para além da situação; visão da totalidade; consciência das origens dos porquês e das finalidades.

Competência pode significar ação, atitude diferente da valorização dos conhecimentos em situação através das quais o professor constrói conhecimento. Os saberes são mais amplos, permitem que se critiquem, avaliem e superem as competências. A escola não é responsável pelo desenvolvimento de competências e sim, pela formação básica do indivíduo, que terá pela frente o desafio de tornar-se competente, ao longo de sua vida, somando à educação obtida na escola sua experiência de vida e de trabalho. 0 significado das competências deposita no trabalhador a responsabilidade de permanentemente adquirir novas competências, por intermédio de inúmeros e diversos cursos especialmente na área da Educação. Por outro lado, como não existe formação exclusiva nesse nível expressa na lei, tem provocado um crescimento da oferta de cursos de pós-graduação lato sensu (especialização) ou mesmo a introdução neles da disciplina denominada Metodologia do Ensino 
Superior ou Didática do Ensino Superior, voltada especialmente a formação docente.

Para tanto, cabe dizer que área do ensino de arquitetura e urbanismo realizou amplo debate nacional a respeito da renovação e atualização do ensino de arquitetura e urbanismo no Brasil, culminando com a definição das novas Diretrizes Curriculares em dezembro de 1994 (Portaria 1.770, do MEC, de 21/12/94). A publicação de Charter of Archictectural Educacion em junho de 1996, pela UNESCO em conjunto com a União Internacional dos Arquitetos - UIA demonstra a acerto das decisões no Brasil para 0 aperfeiçoamento e atualização dos arquitetos e urbanistas. A Declaração Universal dos Direitos do Homem (1948) completou mais de 50 anos e foi reafirmado na Conferência Mundial da Educação Superior, em Paris, os termos que proclamam, no artigo 26, alínea 1, toda a pessoa tem direito à Educação e 0 acesso aos estudos superiores deve ser aberto em plena igualdade a todos, em função do seu mérito.

A palavra Educação - origina-se de educare que por sua vez vem de educere (e educere) que significa criar, aperfeiçoar. No sentido do atual, educação equivale a formação: formar a personalidade, melhorando-a, corrigindo-Ihe os defeitos. Cientificamente consideradas, educação é o conjunto de ações que conformam o educando. Pressupõe um ser para conformar - 0 educando e suas múltiplas manifestações. A educação é inerente à sociedade humana. Assim, pode-se afirmar que a educação é um processo natural que ocorre na sociedade humana pela ação de seus agentes sociais como um todo, configurando uma sociedade pedagógica, Anastasiou e Pimenta (2005, p. 65)

A Pedagogia tem por objeto de estudo a educação enquanto prática social constrói a teoria pedagógica que supera a idéia simplista que a identifica com o modo de ensinar a matéria e o uso de técnicas de ensino. Mas tem um significado mais amplo e mais globalizante. Conforme Libâneo (1198 apud ANASTASIOU e PIMENTA, 2005, p.22)

"Ela é campo de conhecimentos sobre a problemática educativa 6 na sua totalidade e historicidade, ao mesmo tempo, uma diretriz orientadora da ação educativa. 0 pedagógico refere-se a finalidade de ação educativa, implicando objetivos sociopolíticos a partir dos quais se estabelecem formas organizativas e metodológicas da ação educativa". 
A Didática é uma das áreas da Pedagogia. Ela investiga os fundamentos, as condições e os modos de realizar a educação mediante o ensino. A Didática tem no ensino seu objeto de investigação. Quanto a sua prática, Azzi e Caldeira (1997 apud ANASTASIOU e PIMENTA, 2005, p.73):

"A disciplina didática tem um caráter bastante singular, qual seja, o de propiciar ao professor que com ela trabalha a oportunidade de exercer a docência, ao mesmo tempo que reflete sobre ela".

A didática tem por objeto de estudo o ensino pertencente a área de Pedagogia. Como adjetivo este termo é conhecido desde a antiga Grécia, significando uma ação de ensinar presente nas relações entre os mais velhos e os jovens, crianças e adultos. Essa didática na ação de ensinar começará a ganhar um significado mai específico e autônomo a partir do século XVII com o monge luterano João Amós Comênio ${ }^{23}$ (1562-1670) que escreve a obra "Didática Magna - Tratado da Arte universal de ensinar tudo a todos". A obra apresenta um caráter revolucionário assim como o projeto educacional implícito nela. Nos países da Europa Central, onde havia se instalado a reforma protestante, Comênio e outros pautados por ideais ético-religioso desenvolveram o que acreditavam ser um método único para ensinar tudo a todos. Especialmente a ler e escrever, começando pela língua materna, quando predominava o latim. Ensinar toda a população para permitir o acesso direto às Escrituras sem intermédio da Igreja católica, especialmente da Companhia de J esus, com Ignácio de Loyola ${ }^{24}$, iniciou o processo de escolarização no Brasil e que aqui permaneceu até a sua expulsão pelo Marquês de Pombal. 0 método de ensino estava contido na obra. com a obra Ratio Atque Institutioni Studiorum (Método Pedagógico dos J esuítas).

Com Didática Magna, Comênio pretende que a didática seja um processo seguro de instituir em todas as comunidades de qualquer reino cristão que toda a juventude possa ser formada nos estudos, nos bons costumes, enfim ser instruído em tudo que diz respeito à vida presente e futura. Também em Comênio encontramos uma atenção especial à natureza dos conhecimentos a serem ensinados: línguas, matemática, ciência e filosofia.

\footnotetext{
${ }^{23}$ J ohn Amós Comênio (1562-1670) conhecido pelo nome de Mentor das Nações, por ter contribuído para a reforma da Educação em vários países.

${ }^{24}$ Ignácio de Loyola (1491-1556) foi fundador da Ordem dos Jesuítas e autor do livro Exercícios Espirituais.
} 
É aos educadores do século XVII que devemos a consciência do proceder educativo, retirando da Filosofia, da teologia ou da Literatura as cogitações didática pedagógicas.

Nos dois séculos seguintes a Didática sofrerá significativas transformações no âmbito social, político, econômico, cultural e científico.

Rousseau ${ }^{25}$, no século XVIII, será o autor da segunda revolução didática. Sua obra enfatiza um novo conceito de infância, pondo destaque sua natureza e transformando o método de ensinar em um procedimento natural, exercido sem pressa e sem livros.

No século XIX, Herbart ${ }^{26}$ (1776-1841) cria as bases da pedagogia científica, salientando os passos formais de aprendizagem, dos quais decorrem os passos formais do ensino: clareza (na exposição), associação (dos conhecimentos novos com os anteriores), sistema e método.

Se em Rousseau, lançando as bases da Escola Nova ${ }^{27}$, ressalta-se o sujeito que aprende em Herbart a ênfase está no método (de ensinar).

Em seguida, determinadas vertentes tiveram como referencial científico a psicologia das diferenças individuais, a didática oriunda destas correntes tenta fornecer as bases científicas para explicar as diferenças individuais e as desigualdades escolares, - 0 fracasso - como próprias da natureza de cada criança. A valorização da criança com sujeito da aprendizagem se impõe como justificativa da desigualdade escolar e social. Explicando: a escola está disponível a todos e os professores estão nela para ensinar. Se os alunos aprendem ou não, a responsabilidade não é dos professores, de sua didática, de seus métodos, do que ensinam, de como avaliam, de seu relacionamento com os alunos. Tampouco as escolas, como se organizam e selecionam os alunos. Assim, escolas e professores cumpriram os papéis designados pela sociedade. Se por acaso, os alunos não tem condições naturais e sociais para aprender, a responsabilidade escapa à escola e aos professores.

\footnotetext{
${ }^{25}$ J ean Jacques Rosseau - filósofo genebrino, na área da Filosofia da Educação enalteceu a "Educação Natural" e publicou 1762, o livro o Contrato Social.

${ }^{26}$ O filósofo alemão, Johann Fridrich Herbart (1776-1841) no século 19 inaugurou a análise sistemática da educação e mostrou a importância da psicologia na teorização do ensino.

${ }^{27}$ Escola Nova é a corrente pedagógica orientada de um lado, pelo sentimento de solidariedade social, de outro pelo princípio psicológico de atividade como recurso educativo, e ainda de outro, pela finalidade de educar para a vida pela vida. Por seus métodos e técnicas a escola nova se contrapõe à escola tradicional
} 
$\mathrm{Na}$ corrente escolanovista ${ }^{28}$, com as suas raízes na Psicologia experimental, a finalidade da educação está inserida nas leis do desenvolvimento biológico da criança, por isso deve ser realizada com objetividade científica. Então a Pedagogia, enquanto teoria da Educação e a Didática, enquanto teoria do ensino vinculado a primeira ficam restritos aos métodos e aos procedimentos científicos e traduzidos em técnicas de ensinar.

Nesta direção, no final do século XX, com o desenvolvimento tecnológico dos anos 60 , com a informática, o campo da didática se encaminharia ao desenvolvimento de novas técnicas de ensinar, e o ensino, à aplicação delas nas mais diversas situações. A expectativa que a sociedade (dominante) tem da escola: preparar para o mercado de trabalho. É este o critério de avaliação do sistema escolar.

No período entre 1996 e 1999, foram apresentadas várias pesquisas e estudos na área da didática a fim de esclarecer o que é realmente e o que abrange. No ensino estão presentes vários campos de conhecimento: 0 da Pedagogia, áreas da educação, da didática e didáticas específicas. Esses campos têm em comum o estudo da educação em suas múltiplas manifestações. A Educação é inerente à sociedade humana conforme Brandão (1981):

[...] “a Educação está presente em casa, na rua, na igreja , nas mídias em geral e todos nós envolvemos com ela, seja para aprender, para ensinar e aprender e ensinar. Para saber, para fazer, para ser ou para conviver todos os dias misturamos a vida com educação. Com uma vida ou com várias [...]. Não há uma forma única nem um único modelo de educação; a escola não é o único lugar em que ela acontece; o ensino escolar não é a única prática, e o professor profissional não é seu único praticante".

Assim, a educação é um processo natural que ocorre na sociedade humana pela ação de seus agentes sociais, tornando-a uma sociedade pedagógica. Libâneo (1998) exemplifica com inúmeras situações a presença do pedagógico na sociedade. Nas mídias há intervenção pedagógica na televisão, no rádio, nos jornais, em todo o material informativo (guias de turismo, enciclopédias, mapas, vídeos). Nas empresas, há atividades de supervisão e orientação de estagiários. Nos serviços públicos estatais, há

${ }^{28}$ Referente à Escola Nova 
atividades pedagógicas de assistência social, sanitários, de promoção social e ampliam-se programas sociais de medicina preventiva, orientação sexual, etc.

Há, pois, a presença do pedagógico na sociedade, extrapolando 0 âmbito escolar formal e não formal. Segundo Libâneo (1998, p.21) é surpreendente que instituições e profissionais cuja atividade está permeada de ações pedagógicas desconheçam a teoria pedagógica. 0 pedagógico diz respeito a metodologia dos procedimentos.

Acrescente-se que a Pedagogia tem um significado mais amplo e mais globalizante. Conforme Libâneo, ela é um campo de conhecimentos sobre a problemática educativa na sua totalidade e historicidade, ao mesmo tempo, uma diretriz orientadora da ação educativa. Por isso, a Pedagogia é uma ciência sobre a atividade transformadora da realidade educativa. Ela é ciência da e para a educação.

A Didática pertence à área da Pedagogia e procura investigar os fundamentos, as condições e os modos de realizar a Educação mediante 0 ensino. Ela procura ampliar nossa compreensão das demandas que a atividade de ensinar produz, com fundamentos nos saberes acumulados sobre esse assunto. Pode ter a possibilidade de com eles aprender, encontrar respostas ou até, criar novos entendimentos de como proceder à educação. Ela procura esclarecer quais as finalidades do ensinar sob os pontos de vista políticos ideológicos (da relação entre conhecimento e poder, conhecimento e formação das sociedades) éticos (da relação entre conhecimento e formação humana, direito, igualdade, felicidade, cidadania), psicopedagógicos (da relação entre 0 conhecimento e desenvolvimento das capacidades de pensar e sentir, dos hábitos, atitudes e valores) e os propriamente didáticos (organização dos sistemas de ensino, de formatação, das escolas, da seleção do conteúdo de ensino, de currículos, das aulas, dos modos de ensinar, da avaliação, da construção de conhecimentos).

Além disso, a Didática permite que o professores de áreas específicas como: as ciências, as artes, a filosofia, convertam em matéria de ensino, instituindo os limites pedagógicos (da Teoria da Educação) e didáticos (da Teoria do Ensino) na docência de cada uma das disciplinas.

A Didática caberia o desafio de por os professores ativos em um processo de democratização social e política por intermédio de uma educação pública e gratuita para a maior parte da população, até então excluídas e que passou a ter acesso à escola a partir dos anos $60 \mathrm{em}$ um novo quadro social.

Continuando a abordagem sobre didática, vê-se que a importância do ensinar desde os tempos remotos predominou sobre o do 
aprender. A base do conhecimento didático abrangia o professor como personagem principal do processo, somando a ênfase nos métodos e recursos existentes. Desde o início, com a didática de Comênio que tentou uma arte de ensinar tudo a todos, a didática de Herbart com a precisão dos passos formais, a didática de Rosseau, centralizando no ser que aprende e no movimento da Escola Nova, no qual contam os interesses, a motivação é a atividade da criança, o professor é apenas orientador e organizador das situações de ensino, e em tempos mais recentes a crença no poder das tecnologias e das mídias como formas para a transmissão das informações - a aprendizagem tornou-se central.

Ao questionar a ação docente, destaca-se a necessidade de entender claramente 0 que se refere ao ensinar, portanto, ao aprender e apreender. Essas ações são com freqüência consideradas e executadas como ações separadas, desunidas, ouvindo-se de professores, afirmações como: eu ensinei, $o$ aluno que não aprendeu.

Embora, o entendimento da natureza do ensinar como atividade social, tenha como compromisso assegurar que todos aprendam à medida que a escolaridade contribui para a humanização, portanto, para a redução das desigualdades sociais existe 0 falso entendimento sobre os limites destas expressões.

Isso surge da idéia de que ensinar é apresentar ou explicar o conteúdo numa exposição o que os docentes procuram fazer com a maior habilidade de que dispõe. Muitos processos de ensino não passam de meras reproduções de mini-palestras ou de reunião com um determinado número de pessoas expondo determinado assunto. Assim, 0 ato de ensinar resume-se ao momento da aula expositiva encerrando-se nele e não decorreria 0 ato de aprender. Mas a prática social em sala de aula engloba tanto a ação de ensinar quanto a de aprender e apreender com sucesso.

Daí a busca por técnicas de exposição ou oratórias, como sendo o essencial para a competência docente.

Nessa visão de ensino, a aula é o espaço onde o professor fala, diz, explica o conteúdo, cabendo ao aluno anotá-lo para depois memorizá-lo. Mesmo se for considerada uma boa aula expositiva, se o colega tiver um amigo que copia tudo e estudar os conteúdos, suas definições ou sínteses pode prescindir da presença do próprio aluno. 0 professor fica como fonte de saber, tornando-se o portador e a garantia da verdade. Segundo $\operatorname{Not}^{29}$ (1993), isso pode provocar uma adoção da estrutura do outro e, quando se fala ao outro,

${ }^{29}$ Louis Not é autor de "Ensinando a Aprender" 
inclusive, utiliza-se a mesma linguagem, com as mesmas palavras, principalmente na hora da prova.

Em tal processo ficam excluídas as historicidades, os determinantes, a rede teórica que permitiu à ciência chegar até aquela definição ou fórmula, enfim os elementos que possibilitaram aquela síntese obtida; a ausência desses aspectos científicos, sociais e históricos deixa os conteúdos soltos, fragmentados, com fim em si mesmo. Nas aulas para além do o que e do como, deve-se ensinar também a pensar, aspectos que se determinam e condicionam, configurando o ensino como atividade do professor e do aluno, acentuado na atividade do primeiro, e a aprendizagem como atividade do professor e do aluno, acentuada na atividade do segundo. Então a prática social engloba tanto a ação de ensinar quanto a de aprender.

A compreensão do que seja ensinar é fundamental. O verbo ensinar origina-se do latim insignare, que significa marcar com um sinal, que deveria se de vida, busca e despertar para o conhecimento.

E na sala de aula, pode haver a compreensão do conteúdo pretendido ou não, as formas de pensamento mais evoluídas, ou não, enfim, para outras ações envolvendo ações de estudo e de aprendizagem. Ao atingir a meta teria definido o êxito da tentativa e somente diria que houve ensino se tivesse ocorrido aprendizagem.

Porém, o verbo ensinar, empregado com outros verbos de ação, adquire em si, duas dimensões: uma utilização intencional - a intenção da aprendizagem, que nem sempre vem acompanhada da obtenção da meta, ou seja, de resultado - a efetiva ocorrência por parte do aprendiz. A ação de ensinar é definida na relação com a ação de aprender, que revela a intencionalidade, o ensino desencadeia necessariamente a ação de aprender. Ao explicar um conteúdo, o aluno não se apropria dele, houve aprendizagem, ou foi cumprida apenas uma parte do processo. Mesmo havendo a sincera intenção de ensinar, porém a meta (a apreensão, a apropriação do conteúdo por parte do aluno) não se efetivou plenamente, não seria possível prosseguir o caminho escolar, pois não ocorreu a ação de ensinar. As duas dimensões pretendidas na ação de ensinar não foram alcançadas.

Existe também diferença entre aprender e apreender, embora haja entre os dois verbos uma relação entre os sujeitos e o conhecimento.

O apreender do latim apprehendere, significa segurar, pegar, prender, assimilar mentalmente, entender, compreender, agarrar. Para apreender é preciso agir, exercitar-se, informar-se, tomar para si, apropriar-se entre outros fatores. 
O verbo aprender, derivado de apreender (por síncope) significa tomar conhecimento, reter na memória mediante estudo.

Ao estabelecer uma meta para atingir o ensinar é preciso distinguir qual ação estará presente; receber a informação de basta passar por meio de da exposição oral. É o suficiente para a transmissão da informação. Se a meta se referir a apropriação do conhecimento pelo aluno, além do repasse da informação, é preciso se organizar: para superar o aprender na direção do apreender, igual a segurar, apropriar agarrar, prender, pegar, assimilar mentalmente, entender e compreender. Comprehendere, originada do latim, por sua vez significa aprender em conjunto. Isto exige a descoberta ou construção de uma rede de relações, de um sistema em que cada conhecimento é inserido pelo aluno, ampliando ou modificando o sistema inicial, a fim de, a cada contato, alcançar melhor apreensão. Quando isso ocorre, a visão inicial e não elaborada que o aluno trazia inicialmente pode ser superada e reelaborada numa síntese de qualidade superior.

Para Machado, compreender é aprender o significado de um objeto ou um acontecimento; é vê-lo em suas relações com outros objetos ou acontecimentos; os significados constituem, pois, feixes de relações que, por sua vez, se articulam em teias, em redes, construídas socialmente e individualmente e em permanente estado de atualização".

É preciso superar o aprender, o que significa tomar conhecimento de , reter na memória mediante o estudo, a observação ou a experiência, na direção de apreender, que significa segurar, agarrar, prender, assimilar mentalmente, entender, compreender.

A expressão assistir aulas significando a ação de apreender exige informar-se, exercitar-se, instruir-se, enfim, não é passiva. 0 agarrar por parte do aluno exige ação constante e consciente.

Resumindo, a tarefa da didática é a de compreender o funcionamento do ensino em situação, suas funções sociais, suas implicações estruturais; realizar uma ação auto-reflexiva como parte do fenômeno que estuda, porque é parte integrante da trama de ensinar; dialogar com outros campos de conhecimento construídos e em construção, numa perspectiva multi e interdisciplinar; proceder à constantes avaliações do conhecimento produzido no seu campo (as técnicas, os métodos, as teorias) para dele se apropriar e criar novos diante das novas situações que o ensino produzem. Ajudar a criar respostas novas, assumindo uma posição explicativa e projetiva, e crenças sobre a natureza do fenômeno, enfim, suas causas e conseqüências. 


\section{IV - PROCESSOS DE ENSI NAGEM E ESTRATÉGI AS}

Ao apreender determinado conteúdo, apreende-se também determinada forma de pensar sobre ele. Este é o motivo pelo qual cada área exige formas de ensinar e de apreender específicas. Surge então a necessidade de uma competência docente ao definir as ações a serem realizadas pelos seus alunos, visando os objetivos pretendidos. Isto significa ter que estabelecer um processo de apreensão e construção do conhecimento. Para que tal processo se efetive com a parceria e a colaboração do aluno, é importante 0 estabelecimento de uma relação contratual onde, ambos, os parceiros, professor e aluno terão que assumir responsabilidades na conquista do conhecimento.

A esse processo deliberado, compartilhado entre professor e aluno, de trabalhar os conhecimentos, no qual concorrem conteúdo, forma de ensinar e resultados dependentemente recíprocos, é que foi denominado de processo de ensinagem.

Fundamentando, ensinagem ${ }^{30}$ foi o termo adotado pela autora Anastasiou para significar uma situação de ensino da qual necessariamente decorra a aprendizagem, sendo a parceria entre professor e alunos, a condição fundamental para o enfretamento do conhecimento, necessário à formação do aluno durante o cursar da graduação.

Foi também o termo utilizado para indicar uma prática social complexa realizada entre os sujeitos, professor e aluno, reunindo a ação de ensinar e a ação de aprender em um único processo contratual, cujos parceiros deliberados e conscientes, se dedicam à construção do conhecimento escolar resultante de ações efetivadas na e fora da sala.

É uma abordagem sobre a ação de ensino, que resulta na aprendizagem do aluno, superando a exposição oral pelo professor que nada pode afirmar acerca da apreensão do conteúdo pelo aluno. Tentando superar esta exposição é que se inserem as estratégias de ensinagem.

0 processo de ensinar e de aprender na ensinagem exige um clima de trabalho que proporcione um saber (do latim sapere - ter gosto), saborear o conhecimento em questão. 0 sabor é percebido pelos alunos quando o professor ensina algo que também saboreia profissionalmente e/ou

\footnotetext{
${ }^{30}$ A expressão foi inicialmente explicitada no texto de Anastasiou, Lea G. C. resultante da pesquisa de doutorado: Metodologia do Ensino Superior: dá prática docente a uma possível teoria pedagógica. Curitiba
} 
na pesquisa, e a compartilha com os seus parceiros na sala de aula. 0 saber inclui um saber o que, um saber por que e um saber para que.

Assim sendo, o envolvimento dos seus sujeitos é fundamental. Além do o quê e do como, pode se possibilitar pela ensinagem o pensar, situação em que cada aluno possa elaborar as relações dos conteúdos, por meio dos aspectos que se determinam, e se condicionam, numa ação conjunta, isto é, professor e alunos com ações explicadas com clareza nas estratégias selecionadas.

A ação de ensinar não se limita a simples exposição de conteúdos, esperando um resultado positivo.

No processo de ensinagem, os conhecimentos contêm uma determinada coerência, seqüência que leva uma forma específica de percepção, pensamento, assimilação e ação. Conforme citam Anastasiou e Pimenta (2005, p.35), ao apreender-se um conteúdo, apreende-se também determinada forma_de pensar e de elaborar esse conteúdo, motivo pelo qual cada área exige formas de ensinar e de apreender específicas.

Surge aí a importância da competência docente na escolha de ações que esperam serem fixadas sob supervisão, estabelecendo um processo de apreensão e construção do conhecimento.

É diante deste quadro que o professor tem que construir seu trabalho docente e se vê diante da necessidade e do desafio de organizá-lo e operacionalizá-lo. Nesse contexto que se inserem as estratégias de ensinagem. O termo estratégia é adotado como a arte de aplicar ou explorar os meios e condições favoráveis e disponíveis, visando à efetivação da ensinagem.

$\mathrm{Na}$ metodologia tradicional. A principal operação exercitada era a memorização. Atualmente 0 docente deve propor ações que desafiem ou possibilitam o desenvolvimento de operações mentais.

Nestes processos de apreensão são organizados de forma que as operações sejam despertadas, exercitadas e construídas ainda devendo, estar ser vistas e revistas.

É assim que o professor deverá ser um verdadeiro estrategista no sentido de estudar, selecionar, organizar e propor os melhores meios para que os estudantes se apropriem do conhecimento.

No livro "Processos de Ensinagem na Universidade" de Anastasiou e Alves (2007, p.85-105), as autoras apresentam quadro que podem servir de acompanhamento dos processos descritos posteriormente. Estes quadros apresentam varias estratégias, mas seguem um padrão comum. São divididas em quatro partes, compreendendo a descrição, as operações do pensamento, a 
dinâmica da atividade e finalmente a avaliação. São diversas estratégias em quadros, porém foram escolhidas apenas aquelas utilizadas no projeto da livraria.

Para denominar processo, é preciso fazer uma rápida explanação sobre cada uma delas. Saber o que pretendem atingir, as formas de organização, enfim, conhecer as suas etapas e prepará-las, estar atento e disponível, conversando e acompanhando os alunos e os grupos na sala de aula.

0 mesmo ocorre com o quadro ${ }^{31}$ sobre as operações mentais, seu conceito e relações.

É fundamental sua organização com relação às estratégias grupais $^{32}$. Trabalhar em um grupo é diferente de fazer parte de um conjunto de pessoas, sendo fundamental a interação, o comparativo, o respeito ao indivíduo, a habilidade de lidar com o outro, incluindo suas emoções. I sso exige autonomia e maturidade, algo a ser construído com os alunos universitários aos poucos.

0 que caracteriza o grupo além do desenvolvimento inter ${ }^{33} \mathrm{e}$ intrapessoal ${ }^{34}$ é 0 estabelecimento de objetivos compartilhados, que se alteram conforme a estratégia proposta.

Depois de uma atividade grupal de ensinagem, os docentes precisam ter o domínio dos determinantes dessas estratégias; não porque é solicitada no plano pedagógico uma ação discente, mas porque ela terá mais êxito na aprendizagem se assim for realizada. Além disso, é preciso dominar o processo, conhecendo as etapas que envolveram esta estratégia e prepará-las.

Estando os objetivos estabelecidos, claras as etapas os alunos saberão que direção tomar, saberão do encaminhamento do processo. 0 professor precisa estar atento e disponível acompanhando os processos.

De um modo geral, a avaliação é um processo de relacionamento que conduz a uma estimativa. De acordo com a autora, avaliação é um processo abrangente de existência humana, que implica uma reflexão crítica sobre a prática, no sentido de captar seus avanços, suas resistências, suas

\footnotetext{
${ }^{31}$ Este quadro aparece no livro Anastasiou e Alves( 2007, p. 33)

32 Nome que as autora Anastasiou e Alves( 2007, p. 81) chamam trabalho em grupos.

${ }^{33}$ Inteligência interpessoal: reconhecimento de emoções de outras pessoas e habilidades em relacionamentos interpessoais.

${ }^{34}$ Inteligência intrapessoal: autoconhecimento emocional, controle auto-emocional e auto motivação
} 
dificuldades e de possibilitar a tomada de decisão sobre o que fazer para superar os obstáculos.

A escola utiliza uma sistemática quanto à avaliação para promover julgamentos, mesmo sem questionar o processo pelo qual decorreu a aprendizagem, que é individual, próprio de acordo com o tempo, estilo e estratégias. Esta é a chamada avaliação somativa. Esta avaliação é manifestada nas propostas de abordagem tradicional, em que para examinar os resultados obtidos, são utilizados, geralmente, testes e provas, verificando quais os objetivos foram atingidos considerando-se o padrão de aprendizagem e fazendo o registro quantitativo do percentual deles. As críticas à avaliação somativa, na aprendizagem escolar, indicam que o resultado obtido pelos alunos cristaliza-se no registro da nota, transformando a avaliação em uma contabilidade de resultados.

A avaliação formativa consiste na prática da avaliação contínua realizada durante o processo de ensino e aprendizagem. Já essa avaliação é um processo de regulação permanente da aprendizagem realizado por aquele que aprende, conforme Bonniol e Vial (2001 apud ANASTASIOU e ALVES, p. 137):

"Torna-se impossível estabelecer o resultado através das médias de todas as notas obtidas como ocorre freqüentemente, pois elas não têm o mesmo sentido, o mesmo valor, e não correspondem às mesmas aquisições. É preciso elaborar tarefas de controle que permitam fazer o balanço mais exato possível das aprendizagens, assim como prever as grades de análise suficientemente precisas para dar conta de todos os casos individuais".

A qualidade de argumentação, a percepção aguçada e crítica no exame de dados, as habilidades de organização das respostas, os estilos de fala e escrita, o domínio do conteúdo apresentado, participação do grupo durante a exposição complementação de dados, objetividade, riqueza na argumentação formam um conjunto de aprendizagens. É a totalidade da aprendizagem que precisa ser destacada. Quanto mais o processo avançar na complexidade do conhecimento, maior será a conquista. 
Capítulo 03: A DOCÊNCIA NO ENSINO SUPERIOR DE ARQUITETURA

I - O NOVO PAPEL DO PROFESSOR-ARQUITETO

II - TEMAS DE ENSINO DE PROJETO ARQUITETÔNICO NO PRIMEIRO ANO DA GRADUAÇÃO

III - O PROJETO DE UMA LIVRARIA, UMA ESTRATÉGIA 


\section{I - O NOVO PAPEL DO PROFESSOR-ARQUITETO}

“O professor... não é o ponto final do desenvolvimento que os estudantes devem alcançar. Os estudantes não são uma frota de barcos tentando alcançar o professor que já terminou e os espera na praia. 0 professor também é um dos barcos da frota." Freire \& Schor (1987 apud MARQUES e LARA, 2003, p.110)

O estudante de arquitetura tem de ser estimulado a buscar informações, investigar, criticar. A partir deste ponto de vista, o papel tradicional do professor que não se interage com os seus alunos como parceiro, está pronto para ser substituído. 0 professor deve participar do processo de formação, como informam Abreu e Nogueira ${ }^{35}$ (2005). Assim, o novo-professor não formará somente um profissional, mas de um cidadão que irá desenhar os espaços das cidades, portanto, os espaços dos cidadãos.

E como seria a interação entre o professor e 0 aluno?

Para tanto, são criados laboratórios e escritórios-modelos, como constatam Veloso e Elali ${ }^{36}$ (2003, p.100) onde há projetos de prestação de serviços e pesquisas desenvolvidas pela parceria entre alunos e professores.

Para constatação, vale conferir a entrevista realizada junto a professora e arquiteta Dra. Paula Katakura e sua explicação sobre 0 funcionamento do Escritório-Modelo, pois os estudantes de diversos semestres atuam juntos no mesmo trabalho ${ }^{37}$.

Devido ao aumento das instituições de ensino superior na área de arquitetura, 0 aparecimento das faculdades particulares trouxe repercussões quanto ao ponto de vista da formação e do exercício desta profissão. A causa foi a competição profissional tornar-se mais aguçada, portanto, os arquitetos

\footnotetext{
${ }^{35}$ A origem desta Tese de Doutorado foi a partir de um artigo publicado nos anais do II Seminário sobre Ensino e Pesquisa em Projeto de Arquitetura: Rebatimento, Práticas, Interfaces, realizado em 08/11/2005 a 11/11/2005, no Rio de Janeiro. Este evento foi realizado pelo Programa de Pós-Graduação em Arquitetura da Faculdade de Arquitetura e Urbanismo da Universidade Federal do Rio de Janeiro. Inicialmente, a autora participou desse seminário, publicando o artigo intitulado "Ensinar Projeto no Primeiro Ano", escrito junto com o professor e mestre Ivanir Neves Abreu, depois que foi aplicada esta experiência em uma faculdade na cidade de São Paulo. Este artigo consta da bibliografia.

${ }^{36}$ VELOSO, Maísa e Elali, Gleici, no artigo "A pós-graduação e a formação do (novo) professor de projeto de arquitetura" in Marques, Sonia e Lara, Fernando (organizadores). "Projetar: desafios e conquistas da pesquisa e do ensino de projeto". Rio de Janeiro: EVC, 2003, 94-96pp.

${ }^{37}$ Entrevista concedida pela Dra. Paula Katakura a autora em 11/ 2008.
} 
procuravam assumir maior qualificação, o que eles vem fazendo ao longo do tempo através de cursos de pós-graduação lato sensu e stricto sensu. Desta forma, muitos arquitetos além de exercerem a profissão como autônomos, tornaram-se professores universitários. No entanto, eles defrontam com uma série de problemas:

- O reduzido preparo para o exercício da docência;

- A falta de vínculos estáveis;

- Alta rotatividade de professores nas instituições,

- Ineptos didaticamente para o ensino superior.

Para dedicar-se a docência é preciso trilhar os caminhos da pósgraduação, além de precisar ser pesquisador, pois o interesse e a participação em pesquisa são essenciais a um mestre ou doutor, produtor de conhecimento.

Segundo relatam Fernando e Lara, a quantidade de arquitetos lecionando, ainda não está devidamente mapeada, pois, segundo a Associação Brasileira de Escolas de Arquitetura - ABEA, os professores costumam especializar-se em uma disciplina, trabalhando em várias faculdades, principalmente nas grandes cidades e áreas metropolitanas.

O MEC tem incentivado as instituições a buscarem professores mais adaptados para o exercício da profissão por meio das exigências do Índice de Qualificação Docente - IQD, um dos elementos utilizados para avaliar as escolas superiores.

Entretanto, os interessados em dedicar-se a esta área devem refletir sobre como aperfeiçoar suas atividades profissionais, e como se capacitar para o ensino e a pesquisa. E entender 0 significado e as especificidades da atuação docente nesta área.

Atualmente, é quase um consenso que o professor deve ser um educador, não apenas transmitir e repassando conhecimentos adquiridos, mas também fornecendo os instrumentos para a geração de novos conhecimentos.

Desta forma, a linguagem utilizada é saber fazer, que se aliam de modo imprescindível o saber, 0 saber- ensinar e 0 saber-avaliar. Cheikhrouhoud 2002) afirma que na expressão, a dissociação entre o ensino de arquitetura e o exercício profissional uma vez que saber-fazer não significa necessariamente saber-ensinar. Essa separação corrobora as diferenças e os conflitos entre 0 saber-arquitetura, saber-fazer-arquitetura e 0 saberdiscursar-sobre-ela.

O saber corresponde a uma formação teórica e conceitual sólida no que se refere ao conhecimento de princípios e estratégias possíveis de ser 
rebatido no processo projetual, tais como tipologias, analogias, generalizações, conhecimentos de história da arquitetura como referências de projeto.

0 saber-ensinar e 0 saber-avaliar relacionam-se ao desenvolvimento de sua capacidade didático-pedagógico, no que se refere à compreensão do projeto, enquanto um processo dinâmico e criativo, que evolui no tempo.

Aos requisitos anteriores, deve-se se acrescentar o cultivo de um senso crítico capaz de garantir discernimento, aprendizagem, auto-avaliação e reciclagem por parte do docente, ou seja saber-aprender e re-aprender continuamente.

São considerados atributos imprescindíveis à construção do novo docente:

- Formação teórica e conceitual sólida em arquitetura e áreas afins saber;

- Prática que viabilize a compreensão do processo - saber-fazer;

- Senso didático-pedagógico - saber-ensinar e saber-avaliar necessários à transmissão do saber-fazer,

- Senso crítico e auto-crítico - saber-aprender e saber-reaprender.

É necessária a integração entre 0 docente e o estudante para a melhoria do ensino-aprendizagem do projeto, através de troca de experiências e reflexões, e principalmente, quanto à função do (novo) professor de projeto e do (novo) arquiteto que se pretende formar: não só projetista, mas também pesquisador e crítico de arquitetura. Esta tríplice aliança na construção do serarquiteto ajudaria melhorar a qualidade ambiental de nossas cidades, é 0 declaram Lara e Marques.

Ao citar diversas vezes a expressão projeto arquitetônico, pode-se recorrer a algumas definições para o estudante entender a abrangência e 0 significado dela dentro do campo da arquitetura:

[...] "atividade de criar propostas que transformem especificações em um objeto concreto"; (Corona e Lemos, 1972, p.203)

“Modo através do qual são organizados e fixados os elementos de um determinado problema [...] imagem mental do mundo real ou a realizar" (Gregotti, 1975, p. 12). 
[...] "construção concebida com a intervenção de organizar e ordenar plasticamente o espaço e os volumes decorrentes, em função de uma determinada época, de um determinado meio, de uma determinada técnica e de uma determinada intenção;" (Lucio Costa, 1980, p.7)

"Não consiste apenas em fazer coisas belas, nem em fazer coisas úteis, mas em fazer ambas ao mesmo tempo - como um alfaiate que faz roupas e que servem."

(Hertzberger, 1996, p.174)

"Há que se aprender a imaginar o objeto e ao mesmo tempo inventar a sua construção... Do contrário, a escola se torna o lugar de indefinível adestramento do que chamam criatividade, com materiais e métodos quaisquer.

- Onde?

- Por quê?

- Para quem?

- Para quê?

- De quais dimensões?" 38

(J oaquim Guedes, Eupalinos ou o Arquiteto, p. 12)

Embora produzidos em momentos sócio-históricos diferentes as definições mantém como semelhança a perspectiva de uma ação criativa e a expectativa do surgimento de um objeto concreto ou a concretizar. Demonstra a possibilidade de modificar o ambiente de modo deliberado, consciente da responsabilidade que isso representa.

A literatura (como Silva, 1991; Broadbent, 1976; Gregotti, 1975; Alexander, 1971, entre outros) aponta historicamente que o projeto é uma decorrência da divisão social do trabalho que conduziu ao afastamento entre quem produz e quem utiliza o ambiente construído, enquanto reflexo da gradativa distinção entre o pensar e 0 fazer, entre 0 conceber, 0 produzir $e$ o usar o espaço. Nesse sentido, a sociedade evoluiu de um estágio primitivo até um estágio organizado e complexo. Na prática primitiva, a construção era atribuição do próprio interessado que, reproduzindo modelos culturalmente consagrados, eliminava a necessidade de um planejamento prévio. Já em uma sociedade organizada e complexa, a nítida hierarquização social e o alto grau de especialização dificultaram o contato entre o usuário e o executor, de modo que o projeto configura-se como um veículo da comunicação entre ambos. 0 projetista passou a se tornar uma espécie de mediador entre o futuro usuário 
(o cliente do seu projeto) e o construtor, condição que o conduziu ao status de profissional preparado para decodificar desejos do primeiro gerando planos concretos para o segundo. 0 trabalho de um arquiteto começa pela compreensão do tema e de seus condicionantes e tem como objetivo, a elaboração de uma proposta que indique os meios necessários para tornar 0 concreto o futuro imaginado.

Quanto à experiência pedagógica, na maioria das vezes resumese a função de reproduzir o conteúdo que o próprio professor adquiriu quando ainda era aluno. Os professores convidados a dar aula são arquitetos, com intensa experiência profissional e diversas obras publicadas em revistas especializadas. Quando surge o convite para dar aulas, alguns professores não tiveram nenhuma preparação pedagógica e a sua atividade básica é transmitir conhecimento e experiência.

Entretanto, ao pensar na transmissão de conhecimento é necessário considerar a pós-graduação como caminho obrigatório do desenvolvimento do ensino e da aprendizagem. Cabe a pós-graduação 0 espaço para o professor produzir cientificamente por meio da pesquisa. E a prática da pesquisa remete a possível qualificação docente, e conseqüente aprimoramento discente.

Como afirmam Veloso e Elali (2003, p.97) a realização da pesquisa universitária rompe com o formato tradicional do conteúdo das aulas, onde ser profissional e professor tinham o mesmo significado.

Para muitos arquitetos, 0 ato de projetar requer, além da criatividade do projetista, o tratamento adequado do objeto arquitetônico, envolvendo, entre outros aspectos, suas relações com o contexto, seu dimensionamento e funcionalidade, atendimento às necessidades dos usuários e às exigências dos meios de produção e a intenção estética conforme relatam Veloso e Elali (2003, p.101).

No projeto desenvolvido em uma escola de arquitetura, o que está em jogo não é a construção de uma obra e sim a construção de um arquiteto.

0 ensino do projeto arquitetônico, não é uma atividade simples, exigindo do docente capacidade de análise, domínio de técnicas de representação, habilidade para articular a diversidade da natureza, facilidade para interpretar problemas para os mesmos:

“Ensinar isso (a arte e a ciência de projetar) é ensinar a expressar-se. 0 saber requerido para esse ensino não é apenas 
plural, (por que envolve técnica e teoria) mas, também um saber de si. É um deixar-aprender uma disciplina na arquitetura geral, que dê conta das particularidades, sem perder de vista as distâncias entre 0 particular e 0 geral."J antzen (2000 apud VELOSO E ELALI, 2003, p. 102).

Parece ser quase um consenso que o professor deve ser um educador, não apenas transmitindo e repassando conhecimentos adquiridos, mas também fornecendo os instrumentos para a geração de novos conhecimentos, apesar de não participar, muitas vezes dos procedimentos do plano pedagógico da instituição.

Quando os professores ingressam na vida acadêmica e começam a lecionar disciplinas projetuais, as ementas já estão estabelecidas pelo Plano Pedagógico de cada faculdade. O planejamento pedagógico de cada disciplina no início de cada semestre, muitas vezes ocorre de forma individual e solitária, em um curto período, relatam Nogueira e Abreu (2005).

Os resultados obtidos nas aulas projetuais, muitas vezes, não são objeto de estudo ou análise individual no curso ou em espaços específicos como a Associação Brasileira de Escolas de Arquitetura - ABEA, por exemplo, ou mesmo seminários específicos nas próprias faculdades.

Ao professor de graduação cabe formar o futuro projetista, aos docentes da pós-graduação é dada a tarefa de capacitar os futuros

\section{formadores de professores projetistas e também pesquisadores.}

Em geral, nos cursos de graduação as disciplinas de projeto arquitetônico são chamadas de profissionalizantes por constituir-se dos campos de saber destinados à caracterização da identidade profissional do arquiteto e urbanista. 39

\footnotetext{
39 Segundo as Diretrizes Curriculares Gerais Portaria № 1.770 - MEC , de 21 de Dezembro de 1994.

Art. $4^{\circ}$ - São Matérias Profissionais:

- História e Teoria da Arquitetura e Urbanismo;

- Técnicas Retrospectivas;

- Projeto de Arquitetura, de Urbanismo e de Paisagismo;

- Tecnologia da Construção;

- Sistemas Estruturais;

- Conforto Ambiental;

- Topografia;

- Informática Aplicada à Arquitetura e Urbanismo,

- Planejamento Urbano e Regional.
} 
Com o intuito de elaborar uma análise, a ementa de Projeto Arquitetônico $1^{40}$ referente ao curso de graduação de arquitetura possui a seguinte descrição:

\begin{abstract}
“Expressão das propostas de concepção do ordenamento espacial de edificações e conjuntos edificados, mediante 0 desenvolvimento prático da linguagem do desenho e da representação, em níveis gradativos de abrangência e complexidade. Introdução aos processos de projeto arquitetônico; conhecimento e entendimento do tema e programa de intervenção e ordenamento do espaço, no âmbito de uma unidade construída". ${ }^{41}$
\end{abstract}

A disciplina de Projeto Arquitetônico é comum a todos os semestres, só se diferenciando pelo nível de complexidade que cada tema exige. Já o projeto de arquitetura apresentado pelos alunos na etapa final do curso deve ser o resultado das questões que puderam ser levantadas e desta forma deve ser avaliado.

0 procedimento projetual se assemelha em vários cursos de diversas regiões brasileiras, onde parte do curso é destinada a aulas teóricas para a apresentação de projetos de arquiteturas exemplares aos estudantes, e a outra parte é composta pelos chamados atendimentos ou orientações.

A primeira providência junto aos estudantes no início do curso de arquitetura é a divulgação do tema estipulado para cada semestre. Neste formato de aulas, os universitários são instigados a refletir sobre o tema e compreender as necessidades reais da sociedade em que estão inseridos.

0 trabalho de projeto arquitetônico dos alunos costuma ser desenvolvido em equipes, trios ou duplas. Tornou-se difícil o atendimento

\footnotetext{
${ }^{40}$ Segundo as Diretrizes Curriculares Gerais Portaria № 1.770 - MEC , de 21 de Dezembro de 1994:

$\S 30$ - O Projeto de Arquitetura, de Urbanismo e de Paisagismo constitui a atividade criadora, referente à arquitetura das habitações e edifícios em geral, bem como projetos de objetos, paisagens, cidades e regiões. Os temas abordarão problemas de maior interesse social, mediante atenção crítica às necessidades sociais.

${ }^{41}$ Ver Tabela 2.
} 
individual, pela quantidade de tempo suficiente e pela relação professor-aluno, que na maioria das vezes não atende as especificações do MEC ${ }^{42}$.

As aulas começam com a determinação de equipes e com a relação destes nomes aos professores. No local onde este curso foi experimentado as classes tinham aproximadamente 60 alunos, e dois professores ministravam o curso (relação 30:1).

0 próximo passo é a determinação do local onde será realizada a proposta projetual.

Logo que o local da intervenção é determinado, os professores cobram uma visita técnica à área. Nesta visita os estudantes fazem o levantamento minucioso do entorno do local onde será implantada a proposta, apresentando inclusive fotografias e mapas. o completo reconhecimento do local acontece assim que os alunos identificam os seguintes aspectos: ruas de acesso, o sentido do fluxo de automóveis, as calçadas de pedestres, a ocorrência de pontos de iluminação, a presença das árvores e o seu porte, edificações vizinhas, escolas, hospitais, metrôs, terminal de ônibus, equipamentos públicos como postes, bancas de jornal, orelhões, caixas do correio, entre outros.

Complementando estes aspectos, estão os detalhes mais importantes: - a análise da orientação do sol em relação ao terreno proposto, 0 perfil topográfico e os condicionantes legais (Zoneamento) que incidem sobre cada lote.

Após essa etapa, são organizados seminários onde cada equipe mostra o seu levantamento e se posiciona explicando qual postura será tomada para a efetivação do projeto arquitetônico: - é o momento da definição do partido arquitetônico.

Quando é terminada e avaliada essa etapa, as equipes iniciam os estudos de casos. É quando o estudante mais necessita de referências. Pede-se uma análise minuciosa de uma obra arquitetônica referencial para cada equipe.

Após duas ou três semanas, no formato de seminários, os estudantes expõem as suas análises, e compartilham as descobertas sobre cada projeto analisado. Depois de duas ou mais semanas esta etapa é também avaliada.

Então, efetivamente os estudantes começam a pensar no projeto. Surgem as primeiras idéias e os primeiros croquis. Em uma mesma equipe, todos opinam.

${ }^{42}$ O MEC exige 15:1 estudantes por professor. 
Depois de alguns anos lecionando disciplinas de projeto dessa maneira, notou-se que a maioria dos questionamentos das equipes não eram relacionados ao fazer arquitetônico. Poucas eram as discussões referentes à forma de apropriação do espaço, à escolha de elementos construtivos, à forma plástica mais interessante ou ainda a criação de um volume que rompesse com a contextualização espacial vigente.

As questões dentro da equipe se limitavam à distribuição de tarefas entre os elementos do grupo. Na verdade, antes mesmo de iniciar 0 projeto, a equipe era subdividida, e o deveres eram distribuídos da seguinte maneira: um aluno projetava, outro transferia os croquis para o computador, outro fazia a maquete, outro desenhava perspectivas e outro escrevia o memorial descritivo.

Se acontecesse de a mesma equipe se repetir em outro semestre, a distribuição das tarefas era novamente testada, e se o trabalho proposto fosse aprovado, a formação da equipe era mantida.

Essa era a rotina de cada novo semestre das disciplinas de projeto arquitetônico, até o aluno chegar ao Trabalho Final de Graduação TFG, obrigatório no último semestre.

Em cursos de graduação de arquitetura e urbanismo, o diploma é entregue ao aluno que realiza um projeto arquitetônico individual, com livre escolha do tema.

O TFG então é levado a uma banca de arquitetos (dois professores da faculdade e outro convidado de outra instituição). Se o TFG for aprovado (nota igual ou maior que sete), o aluno estará apto para exercer a profissão de arquiteto.

Os problemas nos TFGs foram aparecendo lentamente, e demonstrando a sua fragilidade. Por causa das subdivisões das equipes, e conseqüente especialização de alguns de seus membros, as equipes que obtinham notas mais altas, possuíam um ou mais membros que nunca haviam desenvolvido projetos. Quando era dada a oportunidade para tal atividade, não atingiam nem o nível médio. Era um problema que só aparecia no último semestre do curso, ou seja, na difícil empreitada dos trabalhos finais de graduação (TFGs).

Os professores alocados em bancas de trabalhos finais, às vezes se deparavam com projetos arquitetônicos com qualidade inferior a média, cujo histórico de notas em trabalhos de projeto realizados em equipes não condizia com a realidade. 
Nesse momento foi preciso procurar a gênese do problema. Verificou-se que o primeiro semestre era a única vez que os alunos faziam 0 projeto arquitetônico individualmente. Durante vários semestres era dado como tema o projeto de uma residência unifamiliar. A proporção de número de alunos por professor existente (30:1), não possibilitava orientações individuais.

No final, os professores acabavam orientando mais alguns alunos interessados ou talentosos, pois não havia tempo disponível para entusiasmar todos os alunos restantes.

Lembrando que durante o curso, os projetos arquitetônicos importantes - as referências eram citadas na bibliografia ou rapidamente, ao longo das poucas aulas teóricas introdutórias devido à carga horária restrita a 4 horas por semana.

o tempo era insuficiente para questionamentos ou debates em sala de aula a respeito do espaço gerado para o projeto da residência ou mesmo, sobre outras dúvidas técnicas. Eram sugeridos como referência leituras de projetos de arquitetos consagrados nos âmbitos da arquitetura paulista, nacional e internacional.

Com isso, os alunos que nunca haviam projetado anteriormente, projetavam residências onde reproduziam ${ }^{43}$ os espaços existentes na habitação de cada um, não havendo condições para propostas mais arrojadas ou substanciais.

E só tornavam a fazer projeto individual novamente no último semestre, no Trabalho Final de Graduação - TFG, com uma diferença média de três anos entre a primeira e a última experiência projetual.

Após a Residência Unifamiliar, o tema seguinte no segundo semestre era uma Biblioteca ou um Conjunto de Casas Contíguas, no terceiro semestre uma Galeria de Arte ou um Restaurante, no quarto semestre uma Escola Pública, no quinto semestre um Conjunto Habitacional de Interesse Social, no sexto semestre a continuação do semestre anterior e no sétimo e no oitavo semestres se fazia um revezamento entre os programas mais complexos como Centro Cultural, Edifício Multifuncional ou uma Igreja. Todos os projetos eram realizados em equipes com orientações coletivas.

\footnotetext{
${ }^{43}$ Sobre esse assunto, confrontar com a entrevista com a arquiteta e professora Paula Katakura no capítulo 5.
} 


\section{II-TEMAS DE ENSI NO DE PROJ ETO ARQUITETÔNI CO NO PRI MEI RO ANO DA GRADUAÇÃO}

Durante alguns anos, a participação em um curso de graduação em arquitetura e urbanismo de uma faculdade particular, onde lecionava aulas de Projeto Arquitetônico 1 , levou-me a trilhar o caminho que descrevo adiante.

No primeiro semestre discutíamos sobre que tema seria mais relevante para os alunos compreenderem o que é o projeto de arquitetura. A discussão era sempre motivadora. E a abertura proporcionada pela coordenação do curso, onde o conteúdo disciplinar não era imposto, mas democraticamente decidido, gerava um campo fértil de idéias para o curso de projeto.

As disciplinas de projeto arquitetônico eram numeradas de 1 a 8 . A ementa de Projeto Arquitetônico 1 possuía a seguinte definição :

Expressão das propostas de concepção do ordenamento espacial de edificações e conjuntos edificados, mediante 0 desenvolvimento prático da linguagem do desenho e da representação, em níveis gradativos de abrangência e complexidade. Introdução aos processos de projeto arquitetônico; conhecimento e entendimento do tema e programa de intervenção e ordenamento do espaço, no âmbito de uma unidade construída. ${ }^{44}$

Mesmo para quem não é estranho à carreira do arquiteto e urbanista, o significado da frase propostas de concepção do ordenamento espacial de edificações e conjuntos edificados soa muito abstrato. A utilização destas palavras não permite 0 entendimento imediato de qual seria a atribuição técnica do arquiteto e urbanista.

Segundo as Diretrizes Curriculares de 1998 para os cursos de arquitetura e urbanismo, as habilidades e competências encontradas no campo de conhecimento das disciplinas profissionalizantes de projeto de arquitetura são:

- Habilidade para conceber projetos de arquitetura e urbanismo que satisfaçam as exigências estéticas, técnicas e dos usuários das construções;

\footnotetext{
${ }^{44}$ Ementa da disciplina Projeto Arquitetônico 1 existente na universidade onde a autora ministrava aulas.
} 
- Habilidade de apreender as relações entre os seres humanos e as construções, entre elas e o seu entorno, bem como a necessidade de relacionar as construções e os espaços em função das necessidades e da escala humana. Fatores de custo, especificações e regulamentos.

$\mathrm{Na}$ época em que trabalhava naquela universidade, a disciplina de Projeto Arquitetônico 1 tinha a missão de esclarecer a relação entre o ser humano e 0 ambiente construído. Para tanto, era pedido como desenvolvimento da disciplina exercícios que visavam mostrar essa relação dentro da moradia de cada estudante da graduação.

No total, serão retratados nesse capítulo alguns dos temas abordados na disciplina de Projeto Arquitetônico 1 ao longo desses quase dez anos de docência.

TEMA 1: Projeto de uma Residência Unifamiliar

Começávamos explicando o que era escala gráfica e escalímetro. Depois, pedíamos para que o aluno fizesse um desenho de memória de seu quarto de dormir, com todos os móveis existentes. Ao término da aula pedíamos para que 0 aluno finalizasse o exercício em sua própria casa. Lá, munido de trena, lápis e papel, o aluno confirmaria o desenho de memória realizado em sala de aula. Depois traria para a aula seguinte a planta do desenho do seu próprio quarto de dormir.

0 aspecto positivo deste exercício é o fato do aluno se conscientizar do espaço onde habita. Também, é possível através desse exercício, questioná-lo sobre a disposição e funcionabilidade dos móveis mostrados, além de elucidar a forte relação entre os objetos e as pessoas.

0 exercício seguinte era o desenho do levantamento de todos os ambientes da moradia do estudante da graduação. Era necessário elaborar a planta da sua própria residência, e isso suscitava alguns problemas. Críticas e sugestões, às vezes feitas pelos professores ou pelos próprios alunos, esbarravam em diversos obstáculos. Um deles era a constatação de que a maioria das pessoas habitava uma edificação que não foi projetada, e, portanto cheia de contradições. Por essa razão eram verificados vários problemas de circulação e funcionalidade. Problemas que não poderiam ser resolvidos simplesmente com um rearranjo da mobília. Eram necessárias intervenções 
mais contundentes, que poderiam apontar para uma reforma da planta. E aí outro problema se colocava: caberia a uma disciplina da graduação ensinar a projetar a partir de uma modificação da planta de moradia do próprio aluno? E quais seriam as referências do aluno para resolver o projeto de sua própria moradia?

No primeiro ano da graduação as referências ${ }^{45}$ não foram sequer apresentadas aos estudantes. Em que exemplos 0 estudante deveria se inspirar para realizar projetos eficientes?

0 estudo de referências pode ser uma faca de dois gumes, porque ao reconhecer como referência arquitetônica a residência Paranhos ${ }^{46}$ do arquiteto Vilanova Artigas, o aluno pode simplesmente criar volumes semelhantes, sem estabelecer as relações importantes entre contexto e volumetria, janelas e insolação, circulação e funcionalidade. Por essa razão 0 conhecimento de referências exige a análise da obra frente ao programa de necessidades, onde todo o raciocínio é testado para explicitar certas resoluções. Caso contrário, corre-se o risco das referências serem utilizadas apenas como modelo espacial do volume do ambiente construído, e não fruto de um aprofundamento das questões elaboradas pelo programa de necessidades.

Voltando ao exercício apresentado ao aluno no primeiro ano de graduação, qualquer questão relacionada a projeto, senão for acompanhada por uma aula introdutória com um número significativo de referências arquitetônicas de diversos arquitetos, a referência para o aluno acaba sendo 0 próprio ambiente onde ele habita. Aí se sabe que como a maioria das residências não foi projetada por arquitetos, a chance do estudante se deparar com um bom exemplo é muito difícil.

Os cursos das disciplinas de Projeto Arquitetônico 1 ao ser apresentado aos estudantes não possuíam aulas teóricas, e, portanto, referências fundamentais de arquitetura residencial permaneciam desconhecidas pelos alunos, a não ser que alguns deles pesquisasse em livros ou revistas técnicas, como um autodidata.

Quando era iniciado o exercício efetivamente projetual outro grande problema era a escolha do local onde o projeto da residência unifamiliar seria projetada. Caso escolhêssemos um terreno como a maioria dos existentes na grande São Paulo, seria um terreno estreito e comprido, de medidas da

\footnotetext{
${ }^{45}$ Referências Arquitetônicas é como costuma-se chamar o estudo de arquiteturas exemplares.

${ }^{46}$ A Residência Paranhos é um projeto de 1942, e figura entre o que mais foi influenciados pelos trabalhos do arquiteto americano Frank Lloyd Wrigth
} 
ordem de $5 \mathrm{~m} \times 25 \mathrm{~m}$, ou muito semelhante. Somados os recuos obrigatórios, a largura do terreno caía para $3 \mathrm{~m}$. Quanto mais estreito e mais comprido, mais difícil o trabalho de projetar os ambientes e as circulações. Ainda mais, alunos no primeiro semestre da graduação.

Apesar desses aspectos, esse tema era aplicado no projeto arquitetônico 1, e os resultados finais eram preocupadamente fracos.

TEMA 2: Projeto de uma Residência Unifamiliar

Outro tema abordado para as aulas iniciais de graduação era elaborar um projeto residencial tendo como programa uma poesia encontrada em um pequeno jornal: ${ }^{47}$

\section{Me fazer morar}

Mil metros é minha medida de terra,

Senão grande, suficiente,

Pois necessário mesmo (J oão Cabral sabe)

0 de bom tamanho, nem largo, nem fundo.

Só a parte que me cabe (no final) desse latifúndio

A partir disso é criar

Um castelo no ar

Criar de dentro, uma fez feita;

De fora, quando por fazer

Criar e descansar no sábado

Como foi feito um mundo

E o mundo virou um universo

Universalmente circunscrito à minha casa,

Mesa, prato, meus quadros

Cortinas, à cama.

$\mathrm{Na}$ escala de mil

Ocupar trezentos

Não será plano, nem sobrado.

Terá muitos chãos

Em cada dobra desse solo,

Quero ter a sensação que foi um acidente

E algo se partiu.

Se essa casa ocupa um bloco

Toda a frente do terreno

I magino que atrás, no pátio

Que reservarei a poucos eleitos

esteja a área

ampla e fértil de lazer.

\footnotetext{
${ }^{47}$ Este tema foi trazido para os professores de graduação de Projeto Arquitetônico 1 pela professora Maria Eugênia Ximenes, que possui mestrado realizado na FAUUSP.
} 
Esquartejando minha noção de viver, Descrevo cada parte

Mas nesse ser andrógino que concebo

Há um coração em cada membro

Antes, porém deixo claro

Que o mais significativo em todo o edifício

É o que se presta ao social.

Nos muitos lugares do corpo

Quero ter como largo o dos amigos

Da música(poesia) e dos quadros.

No quarto - quartos não mais que quatro

Um lugar suficiente para o amor

Que por mais espaço que Ihe atribua

Nunca será continente Medida a cama

Uma poltrona para a roupa que se tira

E nada mais é preciso

(só o impreciso do amor)

No meu banheiro não se esqueça da banheira,

Há pecados que só a imersão redime

Pois a banheira sim, ampla e

Se quiser, pouco convencional.

Mentalize uma casa retilínea,

Toda contida num cubo

Agora de um soco nisso tudo

E a construção se desengonça

Resultado: tudo o que imagino para mim Um detalhe vital

Meu estúdio

Não se esqueça que eu pinto

Me alimento de luz

Paz, uma tranqüilidade

Que necessito equilibrar

No quadrilátero de uma tela

(para tanto preciso também nesse ambiente

de uma pia, não esqueça por favor).

Levo a vantagem de ser arquiteto o autor de minha morada

Para ele é fácil saber

Do que se precisa em volta de uma prancheta

Assim como ele sonha o seu trabalho, quero o meu,

Com a solidão e o recolhimento

Que a arte nos impõe

Quero o meu, nem mais nem menos.

Falta pouco

Aos tetos quero brancos

Mas, em alguns desníveis

Meu prazer está no vigamento exposto

Restos de amor andaluz

Tão fortes que dão a impressão

de sustentar o céu

à parte disso, o capítulo do serviço

Deve ser amplo, luminoso

Retilíneo (para não dizer funcional)

Que é pouco poético

A cozinha deve estar a entrada

Ninguém deve ter que avançar por toda a casa

Já da rua - se é preciso- entregar as compras.

O serviço, a lavanderia, quartos, 


\author{
Máquina de lavar, secadora \\ E tudo mais que a poesia não ousa \\ Tudo isso será nessa casa \\ A minha evocação do México que vivi \\ Foi lá que vi tudo isso coroando um terraço \\ E achei que cabia razão \\ Da cozinha, em espiral ascensão \\ Se chegava a azotea \\ Ali todo o serviço - invisível \\ Realizado, tranqüila \\ Por isso o que resta do terreno é lazer \\ Qual a forma dessa casa? \\ Não sei. \\ Existe na informalidade do sonho \\ É só copiar.
}

Este texto foi escrito em 1976 por Luiz Geraldo do Nascimento. Alguns trechos foram cortados para que pudesse se adaptar ao programa semestral de Projeto de Edificações. A palavra azotea é de origem espanhola, na tradução para o português encontra-se a palavra eirado, o mesmo que eira. 0 nome também é aplicado para designar os espaços descobertos situados sobre uma casa ou ao nível de um dos seus andares, cobertura plana do edifício.

A poesia fala de um terreno e de um programa de necessidades que um poeta exprime em forma de poesia. Pede para essa construção tenha alguns níveis, quatro quartos, ampla área para o lazer, terreno de mil metros quadrados, poltrona no quarto principal, banheira no banheiro, cozinha na entrada, traços retilíneos "levemente" desengonçados, estúdio de pintura com pia, telhado com vigamento exposto e outras premissas mais.

A poesia é uma forma interessante do proprietário expressar os desejos da construção e planta de uma casa. A importância de atender esses desejos é o grande desafio para o arquiteto.

Além de todos esses requisitos, a construção deve ser bela, possuir materiais de qualidade e bem escolhidos. 0 principal, porém para uma arquitetura de qualidade, o poeta não conta: - a posição do sol. Ao utilizar 0 poema como método de iniciação ao projeto de arquitetura, esse dado precisa ser especificado para a definição do projeto pelos alunos. Há também outra observação: - o terreno é bastante grande (mil metros), são muitos detalhes programáticos e talvez 0 projeto de uma residência seja 0 mais difícil dos projetos, pela funcionalidade e organização de circulações que os diversos ambientes exigem. 
Os resultados apresentados pelos alunos também foram assustadoramente fracos. Mais uma vez, faltaram referências e conceitos expostos com mais tempo em aulas teóricas.

TEMA 3: Projeto Abstrato

Continuando esse relato de temas abordados na primeira disciplina de projeto arquitetônico, existem aqueles que pouco ou nada parecem ter do ponto de vista arquitetônico. 0 tema do próximo relato poderia ser ministrado em disciplinas semelhantes à Plástica. ${ }^{48}$

0 primeiro passo desse exercício ${ }^{49}$ seria a escolha de um artista e uma obra de arte abstrata. De posse da escolha da obra, devem-se copiar os elementos geométricos que a compõe. Em seguida, montam-se três variações com os mesmos elementos já analisados. As composições devem ser feitas em papel tamanho A3. Após o término dos quatro desenhos, executa-se uma maquete que irá transformar 0 desenho de duas dimensões em obra tridimensional.

É um exercício muito importante para o desenvolvimento da criatividade, bem como da sensibilidade artística. Esse exercício possui conteúdo indispensável em aulas de disciplinas relacionadas à plástica. Mas como trabalho da disciplina de Projeto Arquitetônico 1 pouco pode acrescentar, já que não há como desvincular a existência de um local e um programa para a realização da arquitetura.

TEMA 4: Casa-Cubo ${ }^{50}$

\footnotetext{
${ }^{48}$ No primeiro ano da graduação em arquitetura e urbanismo, aparece uma disciplina que muitas vezes é chamada de Plástica 1 e que tem como ementa: estudo das formas planas e espaciais e suas aplicações. Conceituação de elementos, materiais e técnicas relacionados ao plano bidimensional: experimentação, utilização e aplicação.

${ }^{49}$ O exercício foi descrito pelo professor e arquiteto Osvaldo Saragoza.

${ }^{50}$ Este exercício foi descrito pela arquiteta e professora Dra. Paula Katakura. Apesar da autora não ter participado efetivamente deste tema como abordagem do Projeto Arquitetônico 1, o
} 
O exercício que era feito no primeiro semestre era chamado de Casa-Cubo. Eram dadas as seguintes dimensões: uma largura de 6 metros por um comprimento de 6 metros e por uma altura de 6 metros (um cubo). Esse cubo era dividido em dois andares, onde era feito um arranjo (uma planta). E lá dentro da própria faculdade os alunos criavam um espaço de 1:1 (uma maquete em escala real), para o aluno sentir o espaço que estava sendo criado.

Inicialmente, este exercício poderia servir para sentir o que é um pé direito de 3 metros, mas não era necessário executá-lo para a percepção da forma. Isto porque a ocupação deste espaço como projeto de arquitetura é extremamente insastifatório.

TEMA 5: Habitação de Interesse Social

Durante algum tempo o ensino de Projeto Arquitetônico 1 foi feito a partir da simulação do exercício profissional. Eram utilizados como tema para a disciplina de Projeto Arquitetônico 1 o projeto de uma residência unifamiliar. 0 programa de atividades era passado para os estudantes, como se eles fossem 0 arquiteto, e o professor, o cliente a ser atendido pelo programa de necessidades já elaborado. Esse exercício esbarrava em dificuldades como os do comentário da autoras Veloso e Elali (2003, p.99):

Gradativamente, tal simulação mostrou-se didaticamente inadequada, uma vez que a sala de aula não é um escritório, o professor não é um cliente, sobretudo, o estudante ainda não está vivenciando uma atividade real, ao contrário, encontra-se em uma fase preparatória tanto no que se refere aos conhecimentos necessários quanto em termos de maturidade para enfrentar os problemas que lhe são apresentados.

relato desse exercício é significativo e denota o que será chamado no capítulo 3 de "síndrome do realismo social". 
Assim os temas relacionados à simulação do escritório ${ }^{\mathbf{5 1}}$ foram substituídos pela síndrome do realismo social, no início dos anos 80 . Foi a vez do desenvolvimento de pesquisas em planejamento e projetos de arquitetura politicamente engajados, onde os temas eram ligados à habitação de interesse social, à escolas públicas, bibliotecas, entre outros. A intenção era para que o estudante tomasse consciência de como atender as necessidades da comunidade e também como trabalhar com tecnologias alternativas que buscasse a diminuição do custo das construções, conta Veloso e Elali (2003, p. 100).

o problema era que o tempo usado para diagnosticar os problemas sociais era maior que o tempo disponível para a discussão do procedimento projetual em si:

Além disso, a concepção criativa é submetida à dura realidade sócio-econômica, onde qualquer "excesso" da imaginação é pouco recomendado. Veloso e Elali (2003, p. 100).

Para uma melhor visualização de como o tema do projeto arquitetônico era desenvolvido, é o caso de reproduzir o enunciado dos requisitos de funcionalidade do dormitório de casal, conforme Silva (2006, p. 27):

1. O espaço deverá comportar, no mínimo, uma cama de casal, duas mesas de cabeceira, um roupeiro de três ou quatro portas (duas portas em situação precária) e uma cômoda ou penteadeira, com o respectivo assento.

2. É desejável que, além do equipamento mínimo acima descrito, seja possível a colocação de uma ou duas peças adicionais, como penteadeira ou cômodas separadas, cama infantil ou máquina de costura.

\footnotetext{
${ }^{51}$ Os temas de projeto (geralmente de residências unifamiliares) são chamados de simulação de escritório. 0 projeto das unidades de Habitação de Interesse Social - HIS, na década de 80 foi chamada pelas autoras Veloso e Eulali de sídrome de realismo real, e incluía trabalhos desenvolvidos em mutirões, cortiços e favelas.
} 
3. Os roupeiros e área de utilização devem ser colocados o mais próximo possível da entrada, evitando-se contornar a cama para atingi-los.

4. As áreas de utilização e circulação devem atender aos mínimos indicados no diagrama respectivo, tolerando-se apenas a existência de banco ou cadeira, sempre que a passagem tiver sessenta centímetros ou mais de largura.

5. A implantação do equipamento não deverá dificultar o acesso e/ou o funcionamento da janela, que deverá ser atingível através de uma passagem com largura não inferior a $55 \mathrm{~cm} / 60 \mathrm{~cm}$, tolerando-se a largura de $40 \mathrm{~cm}$ em situação crítica; deve ser garantido o acesso a toda a largura da janela, ou pelo menos a $60 \%$ desta, como solução precária.

6. As áreas de circulação e de utilização de equipamento deverão ser superpostas, a fim de se obter a otimização no uso dos espaços livre.

Programa da Habitação de Interesse Social

Listagem das atividades desempenhadas no âmbito doméstico

\begin{tabular}{|l|l|}
\hline ATIVIDADES BÁSICAS & SUBATIVIDADES PRINCIPAIS \\
\hline REPOUSO & 01 dormir \\
& 02 descansar, ler(deitado) \\
& 03 convalescer de enfermidades \\
& 04 tratar de enfermos \\
& 05 alojar hóspedes eventuais \\
\hline CONVÍ VIO FAMI LIAR E SOCIAL & 06 tomar refeições coletivamente \\
& 07 receber visitantes \\
& 08 conversar \\
& 09 ouvir música \\
& 10 assistir à TV \\
& 11 atender ao telefone \\
\hline ALIMENTAÇÃO & 12 guardar gêneros alimentícios \\
& 13 guardar utensílios de cozinha \\
& 14 preparar alimentos \\
& 15 cozinhar refeições \\
& 16 tomar refeições rápidas \\
& 17 lavar utensílios de cozinha \\
\hline
\end{tabular}




\begin{tabular}{|l|l|}
\hline & 18 eliminar resíduos \\
\hline HIGIENE & 19 tomar banho \\
& 20 lavar rosto e mãos \\
& 21 barbear-se \\
& 22 pentear os cabelos \\
& 23 escovar os dentes \\
& 24 trocar de roupa \\
& 25 fazer ginástica \\
& 26 atender às necessidades fisiológicas \\
\hline LAZER E RECREAÇÃO & 27 descansar \\
& 28 ler (distração) \\
& 29 praticar jogos de mesa \\
& 30 brincar (crianças pequenas) \\
& 31 realizar "hobby" \\
\hline ESTUDO & 32 ler (estudo) \\
& 33 realizar tarefas escolares (escritas) \\
34 realizar trabalhos manuais \\
\hline MANUTENÇÃO DO VESTUÁRIO & 35 reunir roupa suja \\
& 36 lavar roupa \\
& 37 secar roupa \\
38 passar roupa a ferro \\
39 costurar \\
40 guardar roupa \\
\hline MANUTENÇÃO PERTENCES DIVERSOS & 41 guardar objetos pessoais \\
42 guardar material escolar \\
43 guardar materiais de manutenção \\
44 guardar ferramentas leves e diversos \\
45 efetuar pequenos reparos \\
\hline
\end{tabular}

Fonte: Silva (2006, p. 94)

TEMA 6: Exercício Gramático ${ }^{52}$

52 Essa denominação foi dada pelo professor Dr. Antonio Carlos Barossi ao exercício criado pelo professor Dr. Siegbert Zanettini 
No início do curso é apresentada uma foto de uma implantação de um conjunto edificado. Nessa foto aérea não é possível a determinação de como são realmente os volumes, assim como não é possível a definição de quais linhas significam elementos cheios ou vazios. Dado esse exercício para os alunos, eles decidem como deve ser o volume geral do conjunto edificado.

É o primeiro contato do aluno com o objeto arquitetônico. Cabe ao aluno criar a volumetria geral. É nesse momento que o estudante tem de fato uma atividade criadora. Transformar essas linhas em um desenho técnico é outro desafio. Tomando como base a implantação distribuída, os alunos vão criar um novo desenho obedecendo às linhas gerais da matriz distribuída no início. São duas etapas, na primeira são definidas as linhas de contorno da edificação. Na segunda etapa são definidas as linhas das alturas dos vários volumes. As alturas são mostradas através dos desenhos de um corte longitudinal e de um corte transversal. No final dessas etapas, os alunos criam os volumes solicitados e conseguem as medidas equivalentes para a construção de uma maquete volumétrica do conjunto edificado.

É normal que durante a etapa final, o desenho da implantação seja uma releitura da imagem inicial em uma escala pré-determinada. É também o primeiro exercício das disciplinas integradas de uma faculdade pública. 0 resultado final é uma coleção de maquetes volumétricas das mais variadas cores mostrando a diversidade de formas e volumes que podem resultar de uma mesma implantação geral.

Esse exercício é importante porque revela o quanto o estudante conhece de desenho técnico. De acordo com a sua habilidade ele pode produzir uma variedade de volumes de intenções plásticas. 


\section{III - O PROJ ETO DE UMA LI VRARIA, UMA ESTRATÉGI A}

Depois de vários temas testados e após a constatação de alguns problemas, decidiu-se renovar a estrutura do curso de projeto arquitetônico. Começando na disciplina de projeto arquitetônico 1, após vários discussões sobre como poderia ser a mudança do processo de ensino, duas preocupações estimularam essa experiência:

\section{1 - o estudo de arquiteturas exemplares ${ }^{53}$}

\section{2 - a realização de um projeto arquitetônico.}

Mas outras questões se colocaram no caminho: - deve-se atuar na sala de aula seguindo preceitos dos séculos passados, acerca da formatação de aulas? Na procura de ensinar arquitetura, deve-se continuar com 0 desenvolvimento de uma prática que, por vezes, tem rotulado as disciplinas projetuais como independentes, ao ponto de alguns estudantes e professores imaginarem que não há necessidade de um plano de aulas ou de aulas preparadas?

No início deste capítulo, procurava-se a gênese do problema da maioria dos projetos apresentados pelos estudantes, apresentar qualidade inferior ao esperado. Aventou-se a hipótese de que isto ocorria porque não era possível para uma classe de aproximadamente 60 pessoas, agendar atendimentos freqüentes e efetivos, com apenas dois professores.

Ao cogitar outros fatores para a pouca criatividade, especulava-se se não era devido ao pequeno repertório dos ingressantes, assim como o baixo número de aulas teóricas, onde através de uma exposição de arquiteturas exemplares pelo professor, se evidenciava a qualidade de bons projetos e os problemas de um mau projeto.

o professor já se encontrava acostumado ao trabalho desenvolvido com aulas expositivas ou palestras. Este habitus funcionava por meio do oferecimento de conteúdos prontos. Foi desse modo que o professor cursou a faculdade. Os próprios estudantes iniciavam o curso com a expectativa da ocorrência da exposição de aulas teóricas.

Seria necessário um novo procedimento para organizar e operacionar as aulas de projeto arquitetônico. Aulas teóricas só não bastavam

${ }^{53}$ Citado por Edson Mahfuz esta forma de estudo permite a transmissão de conhecimentos arquitetônicos. 
nem despertavam tanto interesse assim. Era necessária a construção de uma nova técnica de aprendizagem e de ensino já no primeiro semestre do curso.

A mudança de procedimentos podia vir através de uma nova tática que substituiria as formas tradicionais memorizativas por reunião de colegas visando à discussão e a reflexão sistemática dos entraves e dificuldades.

Um exemplo seria as reuniões de colegiado para a construção do Projeto Pedagógico da faculdade.

Anastasiou e Alves (2007, p.76) explicam que nos módulos de transmissão de conhecimentos tradicionais, a principal operação do pensamento exercitada era a memorização. 0 docente deveria propor que outras operações do pensamento fossem despertadas e exercitadas.

O tema para o desenvolvimento dessa estratégia foi uma Livraria, devido às seguintes condições:

- O programa de uma livraria é constituído por poucos setores em geral;

- Pode ser considerado um espaço privado com acesso público em horários determinados,

- A existência de uma área para o café pode tornar agradável e singular o ambiente de uma livraria.

Para a realização do trabalho os estudantes teriam que obter e organizar os dados, aplicar os fatos a novas sugestões e compará-la.

0 desenvolvimento do curso seria dividido em 4 fases;

- Descrição: duas etapas

- incluindo os temas propostos para os estudos de caso;

- a elaboração do Projeto de uma Livraria

- Operações do Pensamento: crítica, obtenção e levantamento de dados, comparação, interpretação, resumo;

- Dinâmica da Atividade: compreende 3 momentos

- Preparação: a escolha dos temas dos estudos de caso e o tema da elaboração do projeto de uma Livraria

- Desenvolvimento: apresentação dos estudos de casos

- Relatório: individual ou por grupos

- Avaliação:

- grupos: são avaliados após o seminário, onde cada grupo é avaliado por meio de uma análise incluindo a obtenção e a organização de dados, além da presença;

- individual (projeto da Livraria). 
Foi adotado o termo estratégia ${ }^{54}$ no sentido de proporcionar melhores condições para organizar e selecionar maneiras facilitadoras para que os estudantes se apropriassem do conhecimento.

As novas maneiras de fazer aulas ${ }^{55}$ permitem que 0 estudante atue de forma significativa e responsável, visando a construção do conhecimento.

Um exemplo claro é a da aula expositiva dialogada, que consiste em uma superação da aula expositiva tradicional. Inicialmente, o estudante vai para aula com a intenção de assistir a exposição do conteúdo teórico pelo professor, no entanto, se surpreende com 0 processo de parceria entre 0 professor e o estudante, que fazem a aula acontecer de forma interessante.

A experiência se iniciou no primeiro dia de aula, com uma aula expositiva dialogada onde eram relacionados arquitetos e obras arquitetônicas a partir do conhecimento dos próprios alunos.

O edifício do Museu de Arte Moderna - MASP da arquiteta Lina Bo Bardi e o Conjunto do Memorial da América Latina do arquiteto Oscar Niemeyer despontavam como obras mais conhecidas da cidade de São Paulo.

Ao comentar o MASP, explicando a razão de sua estrutura era obrigatório comentar também o projeto do SESC- Pompéia, ambos projetos de Lina. Para uma classe com aproximadamente sessenta alunos, discorrer sobre a Avenida Paulista ${ }^{56}$ é um pré-requisito simples para pessoas que ainda não conhecem o que é um projeto. Relacionar o porquê do chamado Vão do MASP e comentar sobre a Feirinha de Antiguidades existente, por anos, nos dias de domingo reafirma a idéia de que a arquitetura está ao alcance de todos, e não só de privilegiados.

O Parque do Ibirapuera, também projetado por Oscar Niemeyer em 1954, foi outro local bastante lembrado. 0 conjunto projetado é facilmente reconhecido devido aos volumes das estruturas de concreto armado da Oca e do Planetário. Recentemente, foi acrescentado o Auditório, que com o seu volume prismático também contribui para marcar a paisagem.

\footnotetext{
${ }^{54} \mathrm{O}$ termo estratégia originado do grego strategía e do grego strategia, é a arte de aplicar ou explorar os meios e condições favoráveis e disponíveis, com vista a consecução de objetivos específicos, explica Anastasiou e Alves ( 2007, p.75-76)

55 fazer aulas é como as autoras Anastasiou e Alves definem a nova estratégia de ensino e aprendizagem do tradicional dar aulas

${ }^{56}$ Consultar o mestrado da autora NOGUEIRA (1998)
} 
Outro ambiente construído, utilizado como referência de um projeto de arquitetura, é o SESC- Pompéia. Criado por Lina Bo Bardi no início dos anos 80 (1982) é um espaço agradável e acessível, e possui um aspecto diferencial, já que ele foi projetado em conjunto com a restauração de uma antiga fábrica. Soma-se a esse fato, a intensa programação cultural e têm-se mais uma edificação paulistana importante.

As semelhanças que aproximaram estas três obras é principalmente a possibilidade da convivência no espaço público presente em cada uma dessas edificações.

Nesta relação também pode haver referências negativas.

O Memorial da América Latina ${ }^{57}$, de Oscar Niemeyer é um exemplo. A forma como esse conjunto se coloca na paisagem, dando as costas para o seu entorno, cercado por quilômetros de grades por todo o perímetro externo da edificação, é injustificável. 0 fato dessa obra não interagir com 0 entorno, ao mesmo tempo que não possui uma programação interessante de atividades, colabora para 0 insucesso desse empreendimento.

Observou-se que os alunos começaram a tomar consciência do que é uma obra de arquitetura e alguns até arriscavam opiniões sobre 0 trabalho de Niemeyer.

Definir o que é arquitetura ${ }^{58}$, citando lugares de acesso público como museus, escolas, centros culturais, SESC ou shoppings, é um modo simples e direto. No quadro-negro surgia uma relação assim:

- Centro Cultural São Paulo

- Conjunto Nacional

- Estação do Largo 13

- Estação da Luz

- Instituto Tomie Othake

- Faculdade de Arquitetura e Urbanismo da USP - FAUUSP

- FNAC (Av. Pedroso de Morais)

- Centro Cultural da Federação das Indústrias do Estado de São Paulo - FIESP

- Parque do Ibirapuera (o parque e as edificações)

- Pinacoteca do Estado

\footnotetext{
${ }^{57}$ Ver J oaquim Guedes, 1989 ,Oscar Niemeyer na Barra Funda, em São Paulo, Revista da USP, n.5, São Paulo.

${ }^{58}$ Com essas palavras, o arquiteto Joaquim Guedes sintetizava o que era a arquitetura: imaginar o objeto e ao mesmo tempo inventar a sua construção. 0 prefixo arqui (originário do grego arkhi), somado ao sufixo tetura (do grego tékton) significa a "ação de construir na sua mais elevada acepção". Ou simplesmente, "a arte de construir".
} 
- Museu de Arte Moderna - MASP

- Memorial da América Latina

- Museu Brasileiro da Escultura

- Museu da Língua Portuguesa

- SESC Pompéia

- outros.

A idéia era transformar cada local citado e sua respectiva arquitetura em um estudo de caso para o primeiro exercício da disciplina onde é feita a compreensão do que é um projeto.

O tema do exercício era pesquisar cada obra de arquitetura e respectivo arquiteto, contextualizando no tempo e no espaço as influências sofridas por cada um.

Aos poucos, e com um pouco de indução, relacionamos algumas obras importantes, levando os estudantes a perceberem que a maioria desses locais era espaços conhecidos e acessíveis. Dessa forma, estes espaços possibilitariam visitas técnicas, e o conhecimento de uma obra arquitetônica pela percepção do espaço.

A visita técnica em locais como a Faculdade de Arquitetura e Urbanismo da Universidade de São Paulo - FAUUSP projetada pelo arquiteto Vilanova Artigas ou a Pinacoteca do Estado de São Paulo, projeto do arquiteto Ramos de Azevedo, revitalizada pelo arquiteto Paulo Mendes da Rocha, produziria uma sensação nova nos alunos. Lugares nunca antes notados surpreendem pela solução espacial, assim como a sua estética e a sua funcionalidade.

0 método de aprendizagem consistia em agrupar equipes com cada tema de referência arquitetônica. Por exemplo: uma equipe se interessou em estudar o Centro Cultural São Paulo, depois da coletânea de obras arquitetônicas conhecidas relacionadas no quadro-negro.

A pesquisa sobre esta obra envolveria a busca das plantas de arquitetura, antes da visita ao local. Através de orientações dadas pelos professores em grupo, explicamos como entender os desenhos dos edifícios em formas de plantas, cortes e elevações, e depois como utilizá-los para auxiliar o percurso da visita técnica (traçava-se um roteiro no mapa-planta).

Explicamos também a necessidade da pesquisa da vida do arquiteto, enfocando suas influências no campo da arquitetura, o seu período de atuação e outras obras relevantes. Ou seja, a visita seria realizada com uma câmara fotográfica para o registro de imagens atuais e das formas de 
apropriação dos espaços pelos usuários, e também desenhos das plantas, cortes e elevações do edifício. Para essa etapa, foram reservadas duas ou três semanas de orientação às equipes para 0 desenvolvimento do seminário. Dividimos a classe em dois grupos de equipes, e distribuímos através de sorteio um grupo para cada professor.

Um fato a ser comentado foi a decisão de não haver rodízio de professores durante as orientações. Percebe-se que quando o rodízio ocorre, corre-se 0 risco de perder um tempo precioso de reflexão da arquitetura, em troca de questões por vezes de pouco interesse ao aprendizado, como a simples colocação de que os professores costumavam pedir produtos diferentes.

Solucionada esta questão, chegou o dia da apresentação do seminário de cada equipe para o restante da turma. Nesse momento, acreditou-se estar acontecendo o momento primordial do ensino desta disciplina, onde a troca coletiva de informações ofereceu a cada aluno a leitura de diversas obras arquitetônicas, situando-as respectivamente no tempo e no contexto urbano. As apresentações realizadas, não por exigência dos professores, mas por opção dos alunos foi feita através do programa de computação Power-Point. Durante a projeção de desenhos e imagens, a apresentação foi permeada pelas opiniões e constatações de cada membro da equipe.

$\mathrm{Na}$ apresentação final, os alunos mostraram vídeos curtos de entrevistas com usuários dos espaços escolhidos. Este material mesmo não tendo sido pedido pelos professores, acrescentou informações e aliou ainda mais a informática ao ensino da arquitetura.

Sem dúvida, apresentações nesse tipo de veículo de transmissão de informações, privilegiam a organização dos dados e da apresentação de imagens, sendo ideal para uma aula teórica de arquitetura.

Durante a apresentação do seminário, era feita uma leitura da linguagem arquitetônica da edificação, as características e influências do arquiteto que a produziu por meio de frases típicas do meio arquitetônico: a transparência do edifício, a relação do edifício com a cidade, a integração de espaços públicos e privados, a liberação do espaço público para o usuário, entre outras.

Eram frases ouvidas durante as orientações, misturadas com frases encontradas em revistas e livros de arquitetura. 
Consideramos esta forma de aprendizagem e recepção ao mundo da arquitetura importante na medida em que proporcionou um distanciamento da vida anterior ao curso, além de uma postura inicial à crítica de arquitetura.

Os seminários ocorreram sem o controle do tempo de exposição. Pontuamos cada apresentação ministrada pelos alunos com colocações pertinentes a cada arquiteto. A segunda etapa do curso envolveria uma introdução prática ao projeto de arquitetura.

Resolvemos desafiar os alunos encomendando o projeto de uma livraria. É um trabalho individual, só que cada equipe escolhe o arquiteto de sua preferência e referência: ou Rino Levi ou Niemeyer.

A equipe poderia funcionar como um escritório de arquitetura do arquiteto $^{59}$ escolhido, onde seriam determinantes 0 projeto de elementos arquitetônicos marcantes e conceitos presentes na arquitetura desses arquitetos. As orientações seriam coletivas.

Este foi o primeiro programa de necessidades da livraria:

- Área de exposições de livros;

- Áreas menores para exposições de vídeos, CDs, DVDs e papelaria;

- Áreas de estar

- Setor administrativo;

- Setor de serviços e depósito;

- Café,

- Banheiros.

$\mathrm{Na}$ segunda vez que este curso foi oferecido, o programa foi detalhado, buscando mais tempo para esclarecimentos conceituais. Segue o programa detalhado:

\section{Projeto Arquitetônico 01- TEMA: Livraria ${ }^{60}$}

1) Local: Praça Benedito Calixto $x$ Rua Cardeal Verde $x$ Rua Henrique Shaumann ${ }^{61}$

\footnotetext{
${ }^{59}$ Volta-se a tratar do assunto de "simulação de um escritório". Acredita-se que esta simulação aliada ao fato dos estudantes terem realizado um estudo de caso de um arquiteto específico antes de projetar, auxilie o funcionamento dessa estratégia.

${ }^{60}$ Esse programa foi realizado em conjunto com o professor, mestre e arquiteto Ivanir Abreu.
} 
- Área do terreno: 575 m2;

- Área máxima de construção permitida: $2 x$ a área do terreno;

- Área de projeção máxima: igual à área do terreno;

- Recuos: não são necessários;

- Escritório de arquitetura: ( 0 aluno deverá escolher um arquiteto de referência),

- Prever funcionamento das $10 \mathrm{~h} 00 \mathrm{~min}$ até $24 \mathrm{~h} 00 \mathrm{~min}$.

2) Programa de Necessidades:

- Transparência com o espaço externo (atenção a incidência da luz solar);

- "Ilhas" com poltronas, cadeiras e pufes espalhados pela loja;

- Espaço para café (tipo quiosques de shopping) com cinco mesas no máximo;

- Guarda volumes e recepção na entrada;

- Espaço infantil (para encenações, contar histórias, etc.) com Mobiliário feito na escala das crianças;

- As caixas deverão ficar em "ilhas" soltas na loja (somente quatro caixas, com dois caixas em cada ilha);

- Sanitários para público:

- masculino: dois boxes para bacia (prever um para deficientes), quatro cubas e dois mictórios;

- feminino: quatro boxes para bacias (prever um para deficientes), quatro cubas,

- Fraldário:_para dois bebês.

3) Administração e Serviços:

- A administração deverá ser posicionada de maneira a controlar todo o movimento da loja,

- Prever acessos separados para recebimento da mercadoria e públicos;

- Prever total de trinta e cinco (35) funcionários (um gerente + dois administrativos + um estoquista + dois carregadores + dez atendentes + quatro caixas + dois manobristas + quatro faxineiros + quatro atendentes no bar + um atendente na chapelaria + quatro seguranças);

4) Quantidade de Ambientes:

${ }^{61}$ Nesse local hoje existe uma edificação onde se localiza o Fran's Café. 
- Uma sala da administração (área para três funcionários com uma mesa para cada, um armário baixo, um armário alto e dois arquivos);

- Uma sala do estoque (área para quarenta estantes padrão);

- Sanitários para funcionários:

- Masculino: dois boxes para bacia (prever um para deficientes), um box para chuveiro, quatro cubas e dois mictórios;

- Feminino: quatro boxes para bacias (prever um para deficientes), um box para chuveiro, quatro cubas;

- Refeitório para trinta e cinco (35) pessoas,

- Copa (para aquecer almoço, cafés rápidos).

5) Circulações (vertical e horizontal):

- Deverá integrar visualmente todos os espaços;

- Edifício acessível ao deficiente (NBR 9050);

- Elevador com 1,50m x 1,50m (deficientes e distribuição dos livros nos andares);

- Escada com largura de $2,40 \mathrm{~m}$;

- Rampa com largura de 1,80 e declividade de $8 \%$,

- Largura mínima dos corredores 1,50m.

6) Sistema Construtivo:

- Livre;

- Vigas: $10 \%$ do vão (concreto) e $5 \%$ do vão (metálica);

- Pilares: seção redonda (diâmetro de $30 \mathrm{~cm}$ ) e seção retangular variável (dimensionar somente os aparentes),

- Lajes: $20 \mathrm{~cm}$ de espessura.

O programa foi fornecido com a maioria dos ambientes quantificados por meio do número de pessoas que trabalhariam em cada sessão. Assim, os estudantes não precisariam produzir uma releitura do programa e do seu conteúdo. Simplesmente, teriam que setorizar as atividades conforme parâmetros claros e definidos: a posição do sol, a leitura do entorno imediato e a produção de uma arquitetura expressiva que despertasse 0 interesse dos usuários em entrar na livraria.

Para podermos acompanhar a evolução do projeto, sugerimos um caderno de croquis. Os desenhos poderiam ser produzidos sem escala, cortes 
perspectivados, enfim, o principal era que os estudantes desenhassem da forma como sabiam, sem receio de não ter cursado uma escola técnica.

A qualidade do desenho não seria avaliada, mas sim o empenho de cada um em projetar o espaço proposto pelo exercício inicial. Assim, eles estariam se preparando para os demais exercícios projetuais realizados no decorrer do curso de graduação.

A intenção não era para que o resultado arquitetônico fosse arrojado ou despertasse impacto. Mas sim, desenhos e posições pessoais a respeito de cada espaço projetado.

Também não foi pedido um projeto completo dos estudantes, mais croquis e dúvidas, e nisso, a classe correspondeu plenamente.

Os resultados foram interessantes em cerca de $30 \%$ da classe, onde percebíamos claramente 0 empenho e até mesmo 0 talento em comparação à ausência de vocação de alguns alunos.

A programação estabelecida pelos professores, antes do início das aulas, atenderia a seguinte disposição.

Em um primeiro momento, ocorreria uma aula expositiva dialogada com a classe escolhendo as obras mais conhecidas e respectivos arquitetos da cidade de São Paulo.

Neste segundo momento seria feito o estudo de cada caso pelos alunos com abordagens e outros itens salientando as principais características arquitetônicas de cada obra e seu respectivo autor.

0 momento seguinte seriam realizados os seminários dos grupos, e logo após seria feito o Projeto de uma Livraria, com características próprias de cada arquiteto definido anteriormente.

O Projeto da Livraria teria que atender a linha e as características de cada arquiteto (Lina Bo Bardi, Niemeyer ou Artigas), e assim utilizando o este procedimento ficaria demonstrado, que houve encadeamento das três estratégias citadas anteriormente.

A intenção principal do curso ministrado dessa forma passou a ser um mergulho intencional na arquitetura e no seu conjunto de referências para despertar e mesmo distinguir quem deseja seguir esta trilha profissional.

Tratar os alunos como estudantes universitários que são, elevando o nível e o ritmo das aulas, fazendo-os pesquisar, buscar as informações e realizar visitas técnicas, inundando-os de novos conhecimentos. 
É essa a conclusão da aprendizagem do projeto de arquitetura fundamentado em um ensino adequado, cujos desenhos e croquis apresentados mostram interessantes resultados.

Desta forma a experiência foi implantada, e os resultados obtidos, bastante satisfatórios.

\section{ESTRATÉGI AS: Elementos Determinantes}

\section{Estratégia 1 \\ Aula Expositiva Dialogada}

\begin{tabular}{|l|l|l|}
\hline DESCRIÇÃO & $\begin{array}{l}\text { É uma exposição do conteúdo, com a participação ativa dos estudantes, cujo } \\
\text { conhecimento prévio deve ser considerado e pode ser tomado como ponto } \\
\text { de partida. O professor leva os estudantes a questionarem, interpretarem e } \\
\text { discutirem o objeto de estudo, a partir do reconhecimento e do confronto } \\
\text { com a realidade. Deve favorecer análise crítica, resultando na produção de } \\
\text { novos conhecimentos. Propõe a superação da passividade e imobilidade } \\
\text { intelectual dos estudantes. }\end{array}$ \\
\hline $\begin{array}{l}\text { OPERAÇÕES DE } \\
\text { PENSAMENTO }\end{array}$ & $\begin{array}{l}\text { Obtenção e organização de dados/Interpretação/Crítica/ Decisão/ } \\
\text { Comparação/ Resumo. }\end{array}$ \\
\hline DINÂMICA DAVIDADE & DA & $\begin{array}{l}\text { Professor contextualiza o tema de modo a mobilizar as estruturas mentais do } \\
\text { estudante para operar com as informações que este traz, articulando-se às } \\
\text { que serão apresentadas; faz a apresentação dos objetivos de estudo da } \\
\text { unidade e sua relação com a sua disciplina ou curso. } \\
\text { Faz a exposição, que deve ser bem preparada, podendo solicitar exemplos } \\
\text { aos estudantes, e busca o estabelecimento de conexões entre a experiência } \\
\text { vivencial dos participantes, o objeto estudado e o todo da disciplina. } \\
\text { É importante ouvir o estudante, buscando identificar sua realidade e seus } \\
\text { conhecimentos prévios, que podem mediar a compreensão crítica do assunto } \\
\text { e problematizar essa participação. } \\
\text { O forte dessa estratégia é o diálogo, com espaço para questionamentos, } \\
\text { críticas e solução de dúvidas: é imprescindível que o grupo discuta e reflita } \\
\text { sobre o que está sendo tratado, a fim de que uma síntese integradora seja } \\
\text { elaborada por todos. }\end{array}$ \\
\hline AVALIAÇÃO & $\begin{array}{l}\text { Participação dos estudantes contribuindo na exposição, perguntando, } \\
\text { respondendo, questionando... } \\
\text { Pela participação do estudante acompanha-se a compreensão e a análise dos } \\
\text { conceitos apresentados e construídos. } \\
\text { Podem-se usar diferentes formas de obtenção da síntese pretendida na aula: } \\
\text { de forma escrita, oral, pela entrega de perguntas, esquemas, portfólio, } \\
\text { sínteses variadas, complementação de dados no mapa conceitual e outras } \\
\text { atividades complementares a serem efetivadas em continuidade pelos } \\
\text { estudantes. }\end{array}$ \\
\hline
\end{tabular}

Aula Expositiva Dialogada

Fonte: Anastasiou e Alves(2007, p.86) 


\section{Estratégia 1}

\section{Aula Expositiva Dialogada}

A aula expositiva dialogada é uma estratégia que vem sendo proposta para superar a tradicional palestra docente. Há grandes diferenças entre elas, sendo a principal a participação do estudante, que terá suas observações consideradas, analisadas, respeitadas, independente da procedência e da pertinência delas, em relação ao assunto tratado. 0 clima de cordialidade, parceria, respeito e troca é essencial. 0 domínio do quadro teórico relacional pelo professor deve ser tal que "o foi da meada" possa ser interrompido com perguntas, observações, intervenções, sem que o professor perca o controle do processo. Com a participação contínua dos estudantes fica garantida a mobilização, e são criadas as condições para a construção e a elaboração da síntese do objeto de estudo. Conforme o objetivo pretendido, o professor encaminha as reflexões e discussões para as categorias de historicidade, totalidade, criticidade, práxis, significação e para os processos de continuidade e ruptura. 


\section{Estratégia 2 \\ Estudo de Caso}

\begin{tabular}{|c|c|}
\hline DESCRIÇÃO & $\begin{array}{l}\text { É a análise minuciosa e objetiva de uma situação real que necessita ser investigada } \\
\text { e é desafiadora para os envolvidos. }\end{array}$ \\
\hline $\begin{array}{l}\text { OPERAÇÕES DE } \\
\text { PENSAMENTO }\end{array}$ & $\begin{array}{l}\text { Análise/Interpretação/Crítica/ } \\
\text { Suposições/Decisão/ Resumo. }\end{array}$ \\
\hline $\begin{array}{l}\text { DINÂMICA } \\
\text { ATIVIDADE }\end{array}$ & $\begin{array}{l}\text { 1.0 professor expõe o caso a ser estudado ( distribui ou lê o problema para os } \\
\text { participantes), que pode ser um caso para cada grupo ou o mesmo caso para } \\
\text { diversos grupos. } \\
\text { 2. O grupo analisa o caso, expondo os seus pontos de vista e os aspectos sob os } \\
\text { quais o problema pode ser enfocado. } \\
\text { 3. O professor retoma os pontos principais, analisando coletivamente as soluções } \\
\text { propostas. } \\
\text { 4. O grupo debate as soluções, discernindo as melhores conclusões. } \\
\text { Papel do professor: selecionar o material de estudo, apresentar um roteiro para } \\
\text { trabalho, orientar os grupos no decorrer do trabalho, elaborar instrumento de } \\
\text { avaliação. } \\
\text { Análise de um caso: } \\
\text { - Descrição do caso: aspectos e categorias que compõe o todo da situação. } \\
\text { Professor deverá indicar categorias mais importantes a ser analisadas; } \\
\text { - Prescrição do caso: estudante faz proposições para mudança da situação } \\
\text { apresentada; } \\
\text { - Argumentação: estudante justifica suas proposições mediante aplicação } \\
\text { dos elementos teóricos de que dispõe. }\end{array}$ \\
\hline AVALIAÇÃO & $\begin{array}{l}\text { O registro da avaliação pode ser realizado por meio de ficha com critérios a serem } \\
\text { considerados, tais como: } \\
\text { - aplicação dos conhecimentos (a argumentação explicita os conhecimentos } \\
\text { produzidos a partir dos conteúdos?); } \\
\text { - coerência na prescrição (os vários aspectos prescritos apresentam uma } \\
\text { adequada relação entre si??); } \\
\text { - síntese. }\end{array}$ \\
\hline
\end{tabular}

Estudo de Caso

Fonte: Anastasiou e Alves(2007, p.98)

\section{Estratégia 2 \\ Estudo de Caso}

A estratégia de estudo de caso oportuniza a elaboração de um forte potencial de argumentação de um forte potencial de argumentação com os estudantes e refere-se tanto ao momento de construção do conhecimento como da síntese. Os aspectos relacionados à mobilização para o estudo são determinantes para o envolvimento de todos no estudo e na busca de solução do caso proposto. o caso deve estar incluído no contexto de vivência do estudante, ou em parte de uma temática em estudo. Quanto mais desafiador for 0 assunto, maior a possibilidade de manter os estudantes envolvidos. As 
soluções não devem ser comparadas com as dos demais grupos, mas sim quanto ao esforço do próprio grupo. Preponderam aqui categorias da construção do conhecimento como a da significação e da práxis.

\section{Estratégia 3}

\section{Seminário}

\begin{tabular}{|c|c|}
\hline DESCRIÇÃO & $\begin{array}{l}\text { Trata-se de estudo de um tema a partir de fontes diversas a serem } \\
\text { estudadas e sistematizadas pelos participantes, visando construir uma visão } \\
\text { geral, como diz a palavra, " fazer germinar" as idéias. Portanto, não se reduz } \\
\text { a uma simples divisão de capítulos ou tópicos de um livro entre grupos. }\end{array}$ \\
\hline $\begin{array}{l}\text { OPERAÇÕES DE } \\
\text { PENSAMENTO }\end{array}$ & $\begin{array}{l}\text { Análise/Interpretação/Crítica/ levantamento de hipóteses/Busca de } \\
\text { Suposições/ Obtenção de organização de dados/ comparação/ Aplicação de } \\
\text { fatos a novas situações. }\end{array}$ \\
\hline $\begin{array}{ll}\text { DINÂMICA } & \text { DA } \\
\text { ATIVIDADE } & \end{array}$ & $\begin{array}{l}\text { Três momentos: } \\
\text { 1. Preparação - papel do professor é fundamental: } \\
\text { - } \text { apresentar o tema e/ou selecionál0 conjuntamente com os } \\
\text { estudantes, justificar sua importância, desafiar os estudantes, } \\
\text { apresentar os caminhos para realizarem as pesquisas e sua diversas } \\
\text { modalidades ( bibliográfica, de campo ou de laboratório); } \\
\text { - } \quad \text { organizar o calendário para as apresentações dos trabalhos dos } \\
\text { estudantes; } \\
\text { - } \text { orientar os estudantes na pesquisa(apontar fontes de consulta } \\
\text { bibliográfica e/ou pessoas/ instituições) e na elaboração de seus } \\
\text { registros para a apresentação ao grupo; } \\
\text { - organizar o espaço físico para favorecer o diálogo entre os } \\
\text { participantes. } \\
\text { 1. Desenvolvimento: } \\
\text { - Discussão do tema, em que quem está secretariando anota os } \\
\text { problemas formulados, as idéias-chave, as soluções e as conclusões } \\
\text { encontradas. Cabe ao professor dirigir a sessão de crítica ao final de } \\
\text { cada apresentação, fazendo comentários sobre cada trabalho e sua } \\
\text { exposição, organizando uma síntese integradora do que foi } \\
\text { apresentado. } \\
\text { 3. Relatório: trabalho escrito em forma de resumo, pode ser produzido } \\
\text { individualmente ou em grupo. }\end{array}$ \\
\hline AVALIAÇÃO & $\begin{array}{l}\text { Os grupos são avaliados e exercem também a função de avaliadores. } \\
\text { Os critérios de avaliação devem ser adequados aos objetivos da atividade em } \\
\text { termos de conhecimento, habilidades e competências. } \\
\text { Sugestão de critérios de avaliação: } \\
\text { - clareza e coerência na apresentação; } \\
\text { - domínio do conteúdo apresentado; } \\
\text { - participação do grupo durante a exposição; } \\
\text { - utilização de dinâmicas e/ou recursos audiovisuais na apresentação. }\end{array}$ \\
\hline
\end{tabular}

Seminário

Fonte: Anastasiou e Alves(2007, p.97) 


\begin{tabular}{|c|c|}
\hline $\begin{array}{l}\text { OPERAÇÕES DE } \\
\text { PENSAMENTO }\end{array}$ & CONCEI TO / RELAÇÕES \\
\hline COMPARAÇÃO & $\begin{array}{l}\text { Examinar dois ou mais objetos ou processos com intenção de } \\
\text { identificar relações mútuas, pontos de acordo e desacordo. } \\
\text { Supera a simples recordação, enquanto ação de maior } \\
\text { envolvimento do aluno. }\end{array}$ \\
\hline RESUMO & $\begin{array}{l}\text { Apresentar de forma condensada da substância do que foi } \\
\text { apreciado. Pode ser combinado com a comparação. }\end{array}$ \\
\hline OBSERVAÇÃO & $\begin{array}{l}\text { Prestar atenção em algo, anotando cuidadosamente. Examinar } \\
\text { minuciosamente, olhar com atenção, estudar. Sob a idéia de } \\
\text { observar, existe o procurar, identificar, notar e perceber. Ė uma } \\
\text { forma de descobrir informação. Compartilhada. Amplia o } \\
\text { processo discriminativo. Exigem objetivos definidos, podendo ser } \\
\text { anotadas, esquematizadas resumidas e comparadas. }\end{array}$ \\
\hline I NTERPRETAÇÃO & $\begin{array}{l}\text { Processo de atribuir ou negar sentido à experiência, exigindo } \\
\text { argumentação para defender o ponto proposto. Exige respeito } \\
\text { aos dados e atribuição de importância, casualidade, validade e } \\
\text { representatividade. Pode levar a uma descrição inicial para } \\
\text { depois haver uma interpretação do significado percebido. }\end{array}$ \\
\hline CRÍTICA & $\begin{array}{l}\text { Efetivar julgamento, análise e avaliação, realizando o exame } \\
\text { crítico das qualidades, defeitos, limitações. Segue referência a } \\
\text { um padrão ou critério. }\end{array}$ \\
\hline $\begin{array}{l}\text { OBTENÇÃO E } \\
\text { ORGANIZAÇÃO DOS } \\
\text { DADOS }\end{array}$ & $\begin{array}{l}\text { Obter e organizar dados são a base de um trabalho } \\
\text { independente; exigem objetivos claros, análise de pistas, plano } \\
\text { de ação, definição de tarefas, chaves, definição e seleção de } \\
\text { respostas e de tratamento das mesmas, organização e } \\
\text { apresentação do material coletado. Requer identificação, } \\
\text { comparação, análise, resumo, observação, classificação, } \\
\text { interpretação, crítica, suposições, imaginação, entre outros. }\end{array}$ \\
\hline $\begin{array}{l}\text { APLICAÇÃO DE FATOS E } \\
\text { PRINCIPIOS A NOVAS } \\
\text { SITUAÇÕES }\end{array}$ & $\begin{array}{l}\text { Solucionar problemas e desafios, aplicando aprendizados } \\
\text { anteriores, usando a capacidade de transferências, aplicações e } \\
\text { generalizações ao problema novo. }\end{array}$ \\
\hline
\end{tabular}

Tabela 3 - Operações do Pensamento e Conceitos/Relações

Fonte: Anastasiou e Alves (2007, p. 33) 


\begin{tabular}{|c|c|c|}
\hline SEMESTRES & EMENTAS & TEMAS \\
\hline $1^{0}$ SEMESTRE & $\begin{array}{l}\text { Expressão das propostas de concepção do ordenamento espacial de edifica- } \\
\text { ções e conjuntos edificados, mediante o desenvolvimento prático da língua- } \\
\text { gem do desenho e da representação, em níveis gradativos de abrangência e } \\
\text { complexidade. Introdução aos processos de projeto arquitetônico; } \\
\text { conhecimento e entendimento do tema e programa de intervenção e } \\
\text { ordenamento do espaço, no âmbito de uma unidade construída. }\end{array}$ & $\begin{array}{l}\text { Residência } \\
\text { Unifamiliar }\end{array}$ \\
\hline $2^{-0}$ SEMESTRE & $\begin{array}{l}\text { Expressão das propostas de concepção do ordenamento espacial de } \\
\text { edificações e conjuntos edificados, mediante o desenvolvimento prático da } \\
\text { linguagem do desenho e da representação, em níveis gradativos de } \\
\text { abrangência e complexidade. Desenvolvimento da prática projetual em } \\
\text { edificaçóes de pequeno porte, destinadas a diferentes utilizaçôes, } \\
\text { aperfeiçoando a metodologia de proposição de espaços. }\end{array}$ & \begin{tabular}{|l|} 
Vila \\
Biblioteca \\
Pública \\
Restaurante
\end{tabular} \\
\hline $3^{0}$ SEMESTRE & $\begin{array}{l}\text { Expressão das propostas de concepção do ordenamento espacial de } \\
\text { edificações e conjuntos edificados, mediante o desenvolvimento prático da } \\
\text { linguagem do desenho e da representação, em níveis gradativos de } \\
\text { abrangência e complexidade. Compreensão e análise de condicio- } \\
\text { namentos para a definiçâo do partido arquitetônico e construtivo em } \\
\text { edificaçôes de médio porte. }\end{array}$ & $\begin{array}{l}\text { Galeria de } \\
\text { Arte }\end{array}$ \\
\hline $4^{4} \stackrel{0}{\text { SEMESTRE }}$ & $\begin{array}{l}\text { Expressão das propostas de concepção do ordenamento espacial de } \\
\text { edificações e conjuntos edificados, mediante o desenvolvimento prático da } \\
\text { linguagem do desenho e da representação, em níveis gradativos de } \\
\text { abrangência e complexidade. Análise e desenvolvimento de programas } \\
\text { arquitetônicos para edificações de maior complexidade e de seus } \\
\text { comprometimentos de conforto e implantação. }\end{array}$ & Escola Pública \\
\hline 5으른 & $\begin{array}{l}\text { Expressão das propostas de concepção do ordenamento espacial de } \\
\text { edificações e conjuntos edificados, mediante o desenvolvimento prático da } \\
\text { linguagem do desenho e da representação, em níveis gradativos de } \\
\text { abrangência e complexidade. Desenvolvimento de programa } \\
\text { arquitetônico para edificaçôes com programas diversificados, } \\
\text { considerando condicionamentos relativos à verticalização e } \\
\text { adequação à topografia. }\end{array}$ & $\begin{array}{l}\text { Conjunto } \\
\text { Habitacional } \\
\text { de } \\
\text { Interesse } \\
\text { Social }\end{array}$ \\
\hline 6을MESTRE & $\begin{array}{l}\text { Expressão das propostas de concepção do ordenamento espacial de } \\
\text { edificações e conjuntos edificados, mediante o desenvolvimento prático da } \\
\text { linguagem do desenho e da representação, em níveis gradativos de } \\
\text { abrangência e complexidade. Análise e desenvolvimento do programa e } \\
\text { projeto arquitetônico para conjunto de edificaçôes, considerando } \\
\text { condicionamentos para unidades edificadas e suas relaçóes de } \\
\text { vizinhança. }\end{array}$ & Continuação \\
\hline $7^{0}$ SEMESTRE & $\begin{array}{l}\text { Expressão das propostas de concepção do ordenamento espacial de } \\
\text { edificações e conjuntos edificados, mediante o desenvolvimento prático da } \\
\text { linguagem do desenho e da representação, em níveis gradativos de } \\
\text { abrangência e complexidade. Desenvolvimento de programa } \\
\text { arquitetônico complexo, em suas relações de construtividade } \\
\text { estrutural e de utilização de materiais em nível executivo. }\end{array}$ & $\begin{array}{l}\text { Edifício } \\
\text { Multifuncional } \\
\text { Centro de } \\
\text { Referência de } \\
\text { Idosos }\end{array}$ \\
\hline $8^{0}$ SEMESTRE & $\begin{array}{l}\text { Expressão das propostas do ordenamento espacial de edificações e conjuntos } \\
\text { edificados, mediante o desenvolvimento prático da linguagem do desenho e da } \\
\text { representação, em níveis gradativos de abrangência e complexidade. } \\
\text { Desenvolvimento de concepção arquitetônica complexa, abrangendo } \\
\text { o estudo e a proposição de implantação que considere a integração } \\
\text { da obra arquitetônica no contexto urbano. Desenvolvimento de } \\
\text { relações com uso de recursos, proteção da paisagem, patrimônio } \\
\text { cultural. }\end{array}$ & \begin{tabular}{|l|} 
Teatro \\
Igreja
\end{tabular} \\
\hline
\end{tabular}

Tabela 4 - Relação de Ementas, Semestres e Temas de Projeto de Uma Faculdade de Arquitetura e Urbanismo (ensino privado)

Fonte: produzido pela autora. 


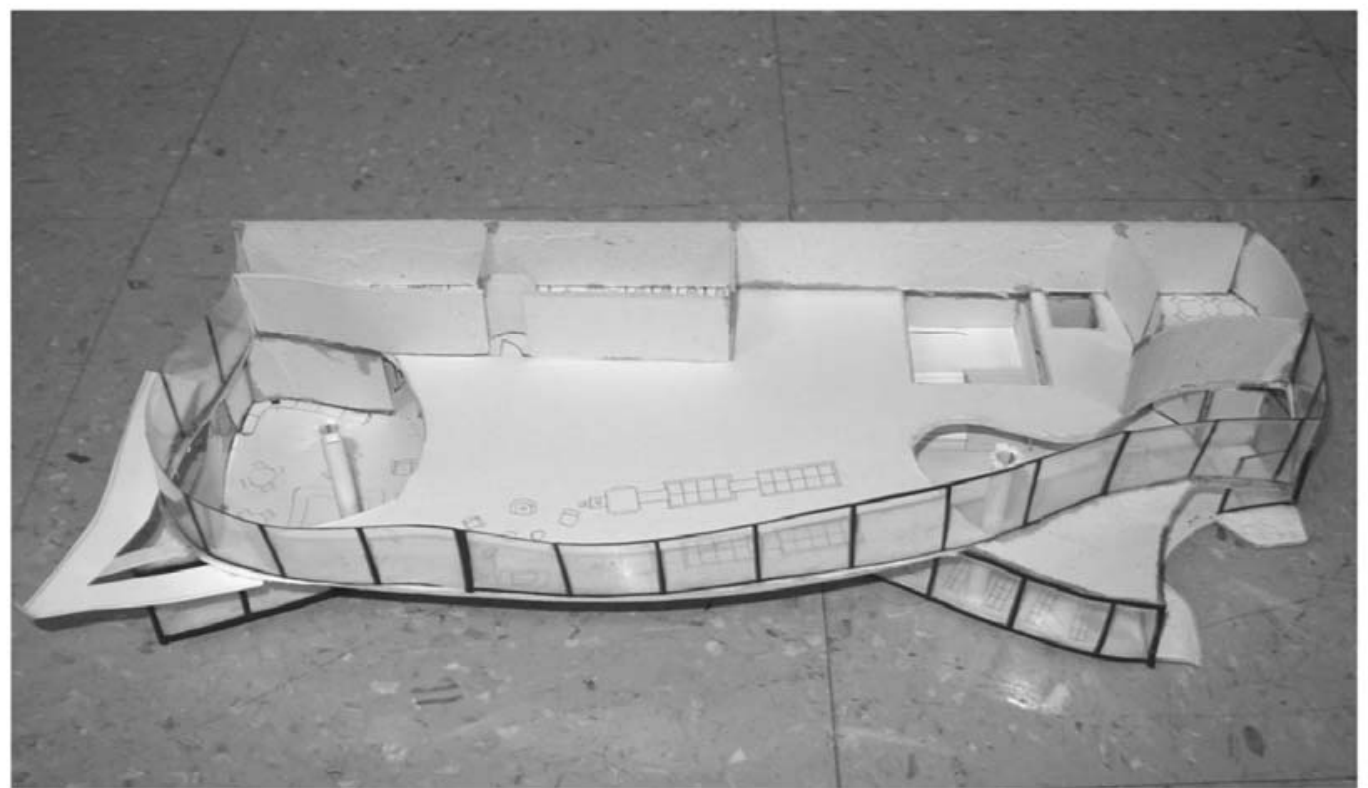

Vista da Maquete elaborada por um dos alunos - 2005

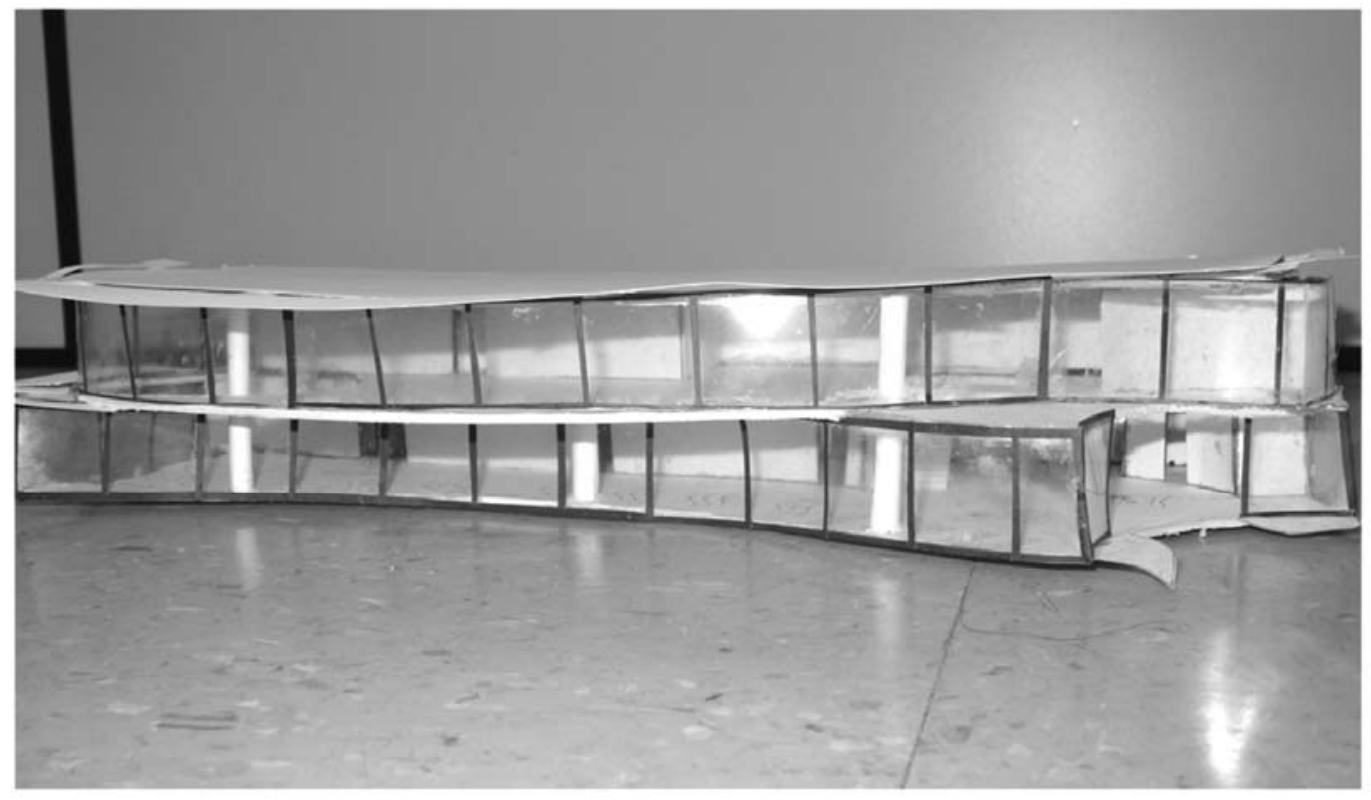

Vista da Maquete elaborada por um dos alunos - 2005 


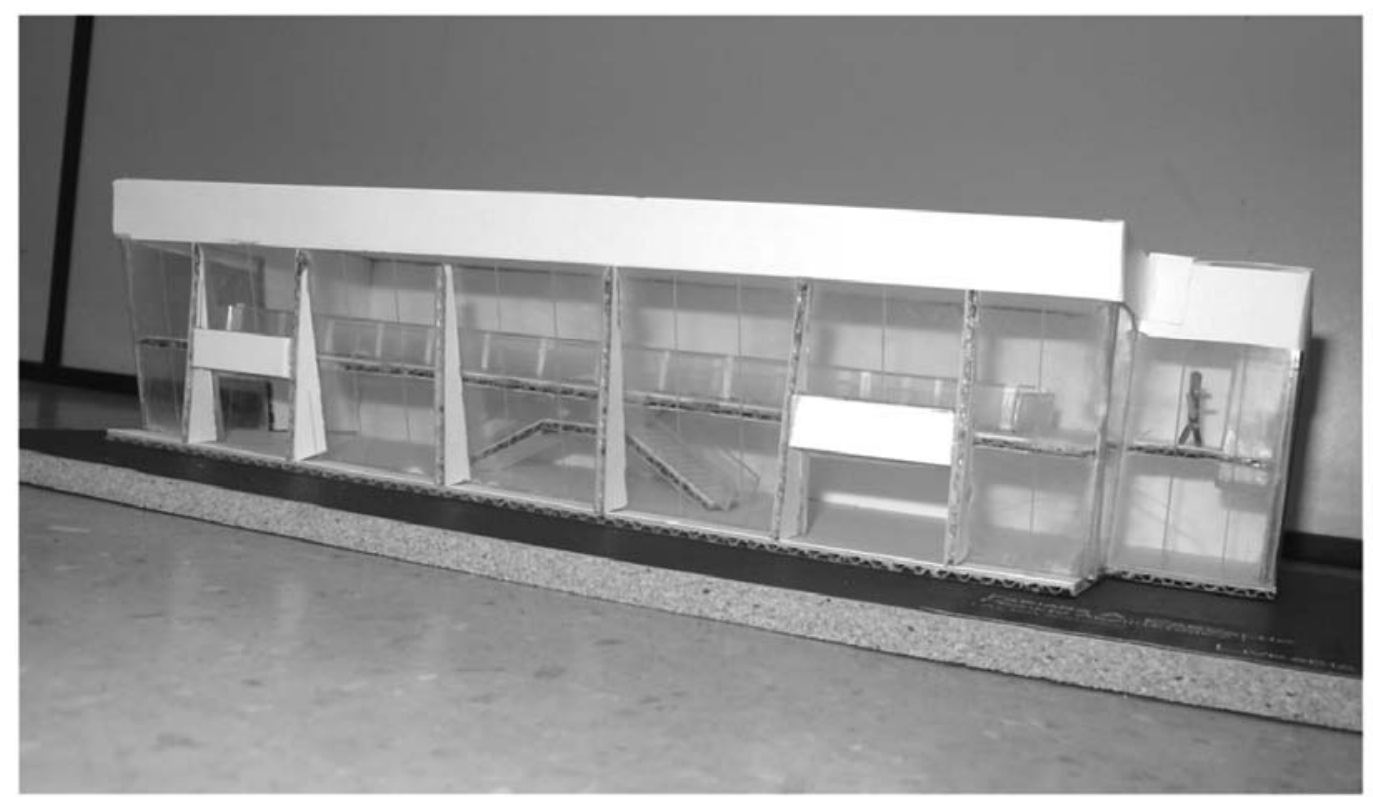

Vista da Maquete elaborada por um dos alunos - 2005

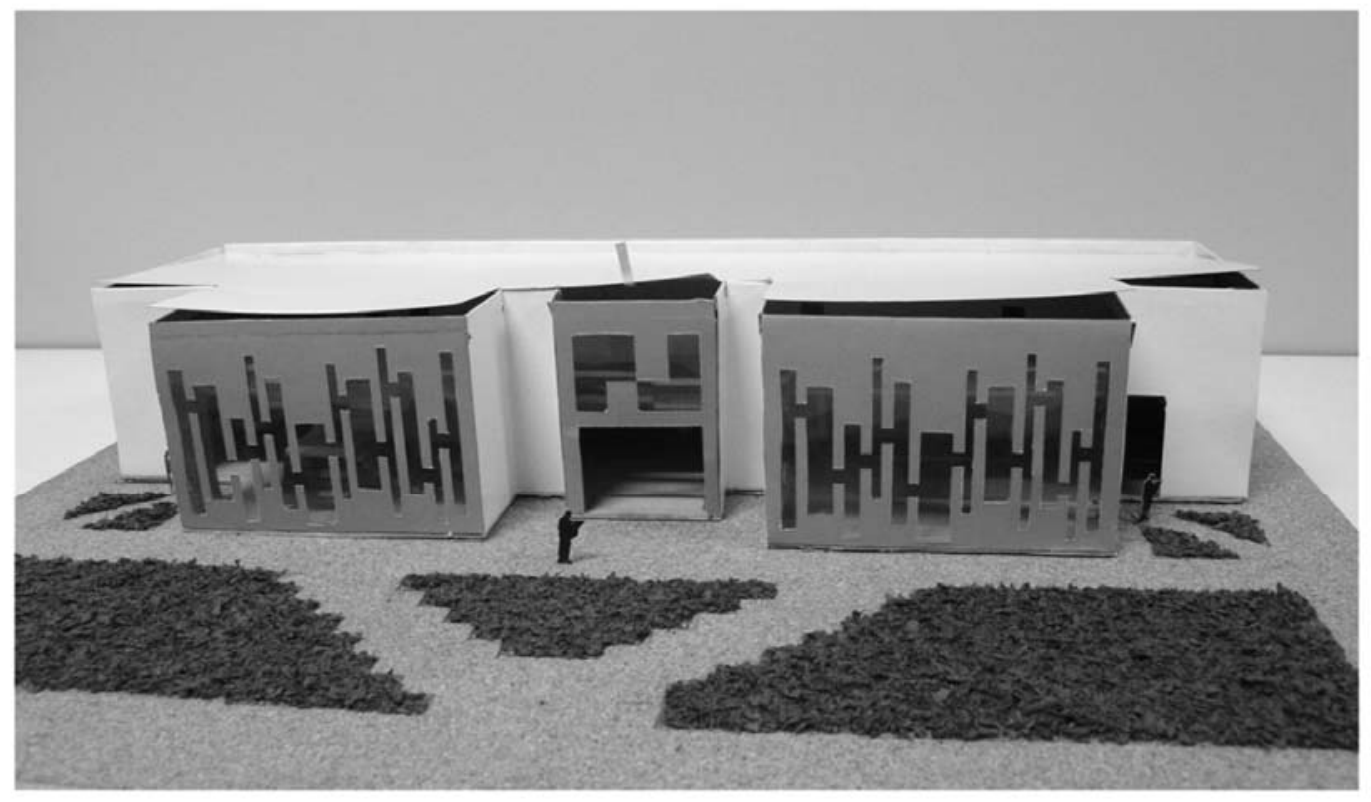

Vista da Maquete elaborada por um dos alunos - 2005 


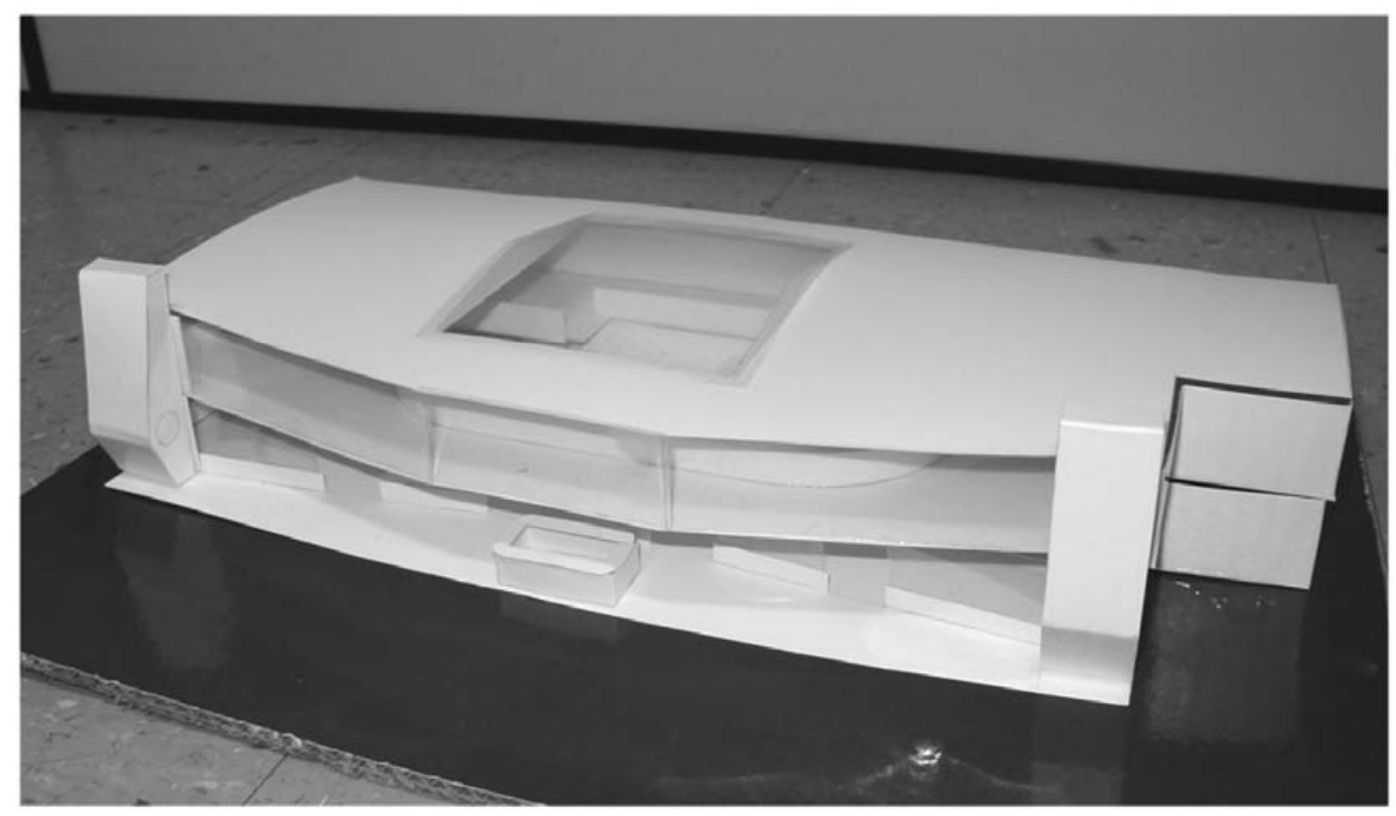

Vista da Maquete elaborada por um dos alunos - 2005

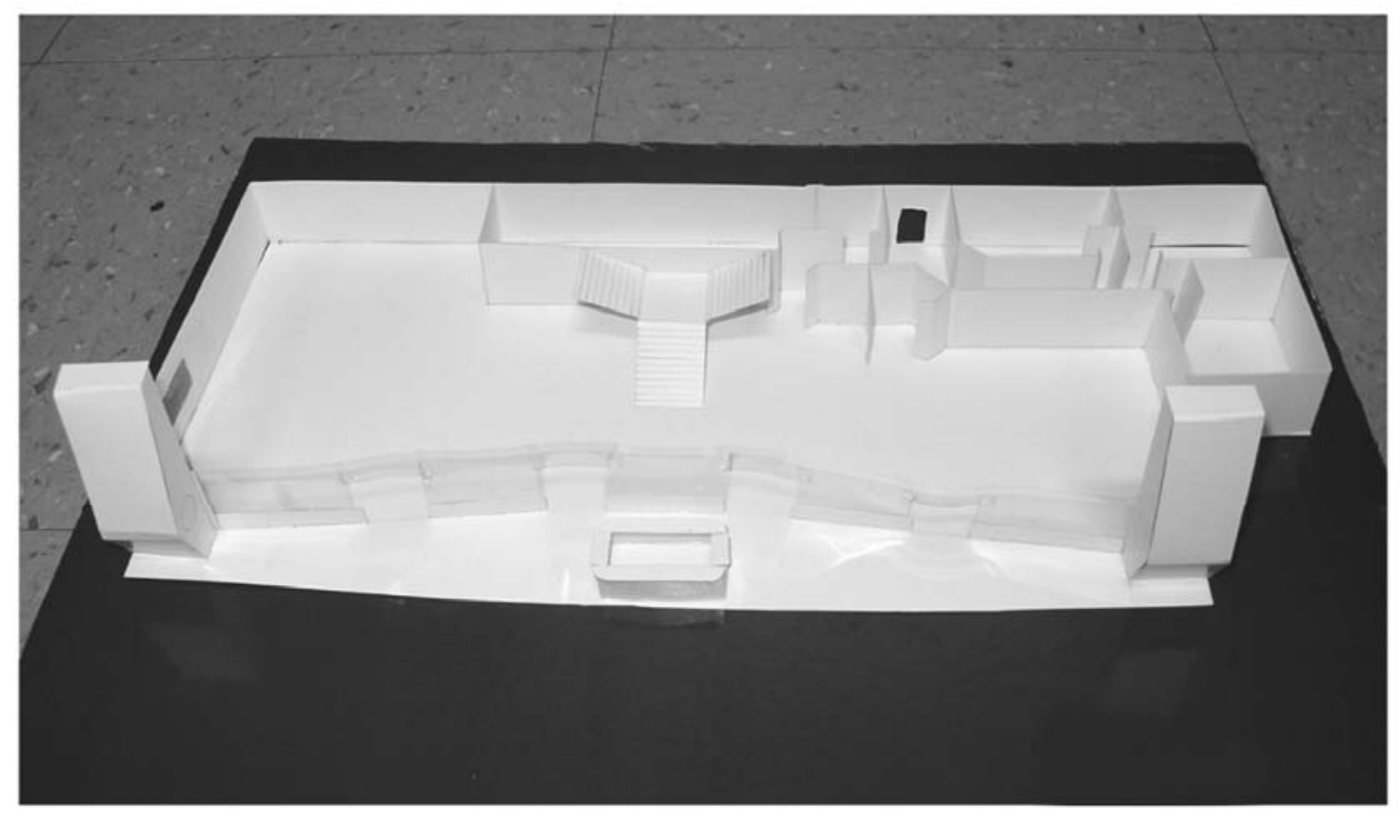

Vista da Maquete elaborada por um dos alunos - 2005 


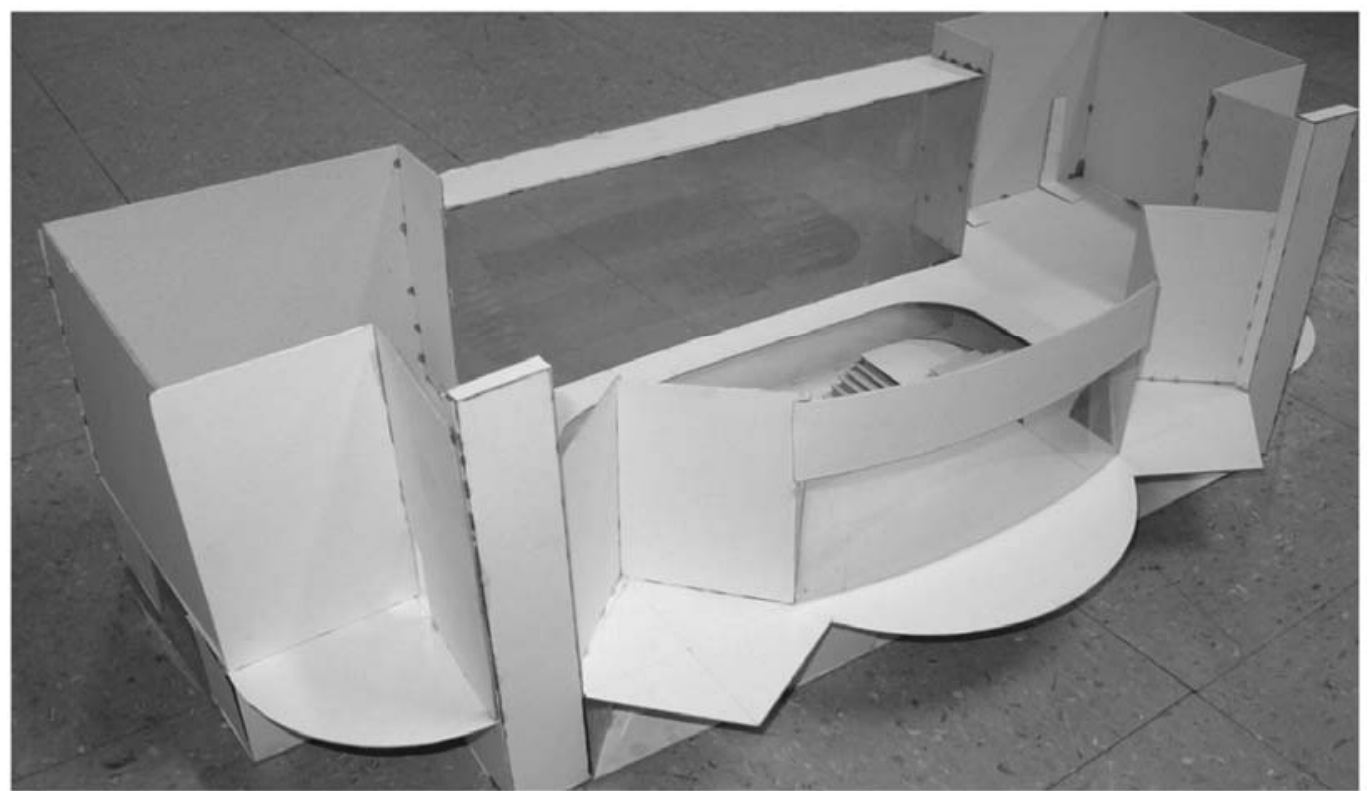

Vista da Maquete elaborada por um dos alunos - 2005

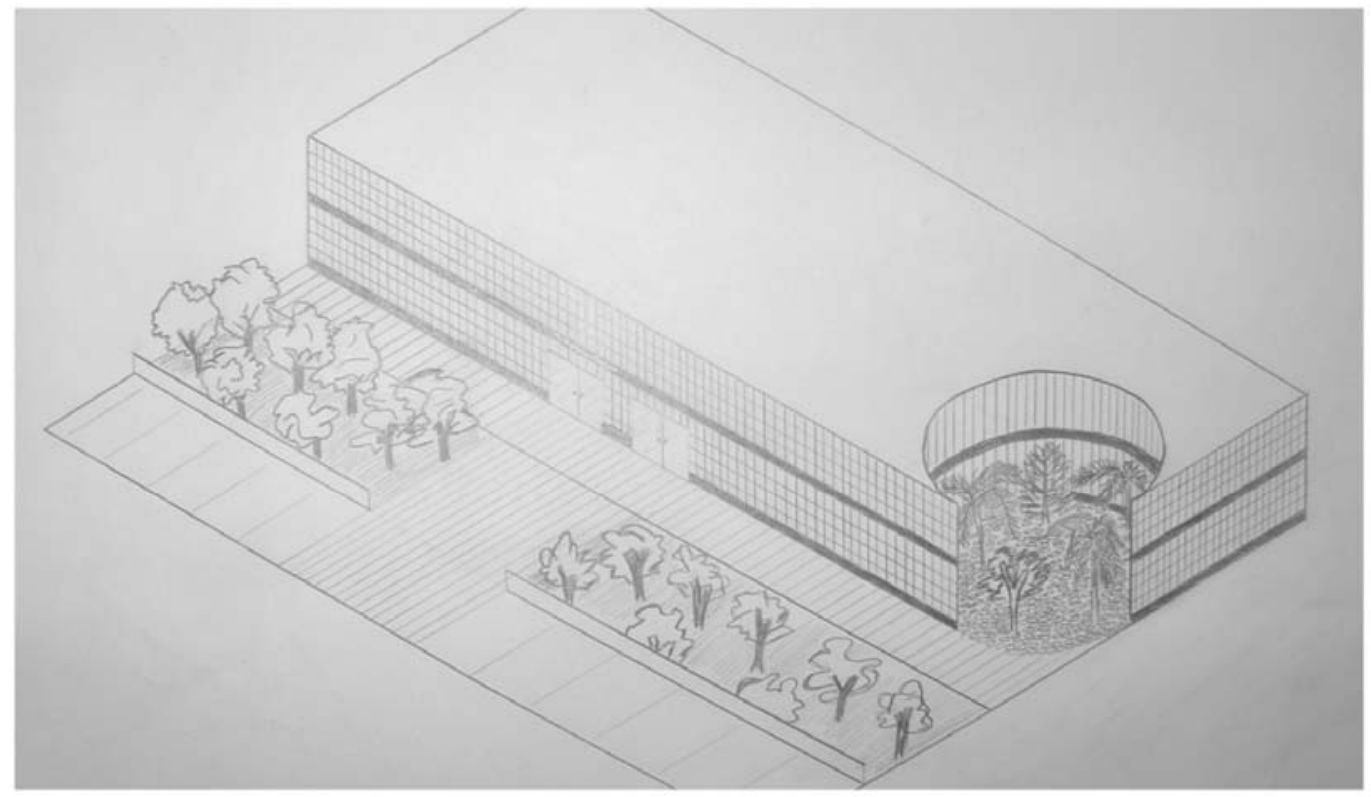

Desenho elaborado por um dos alunos - 2004 


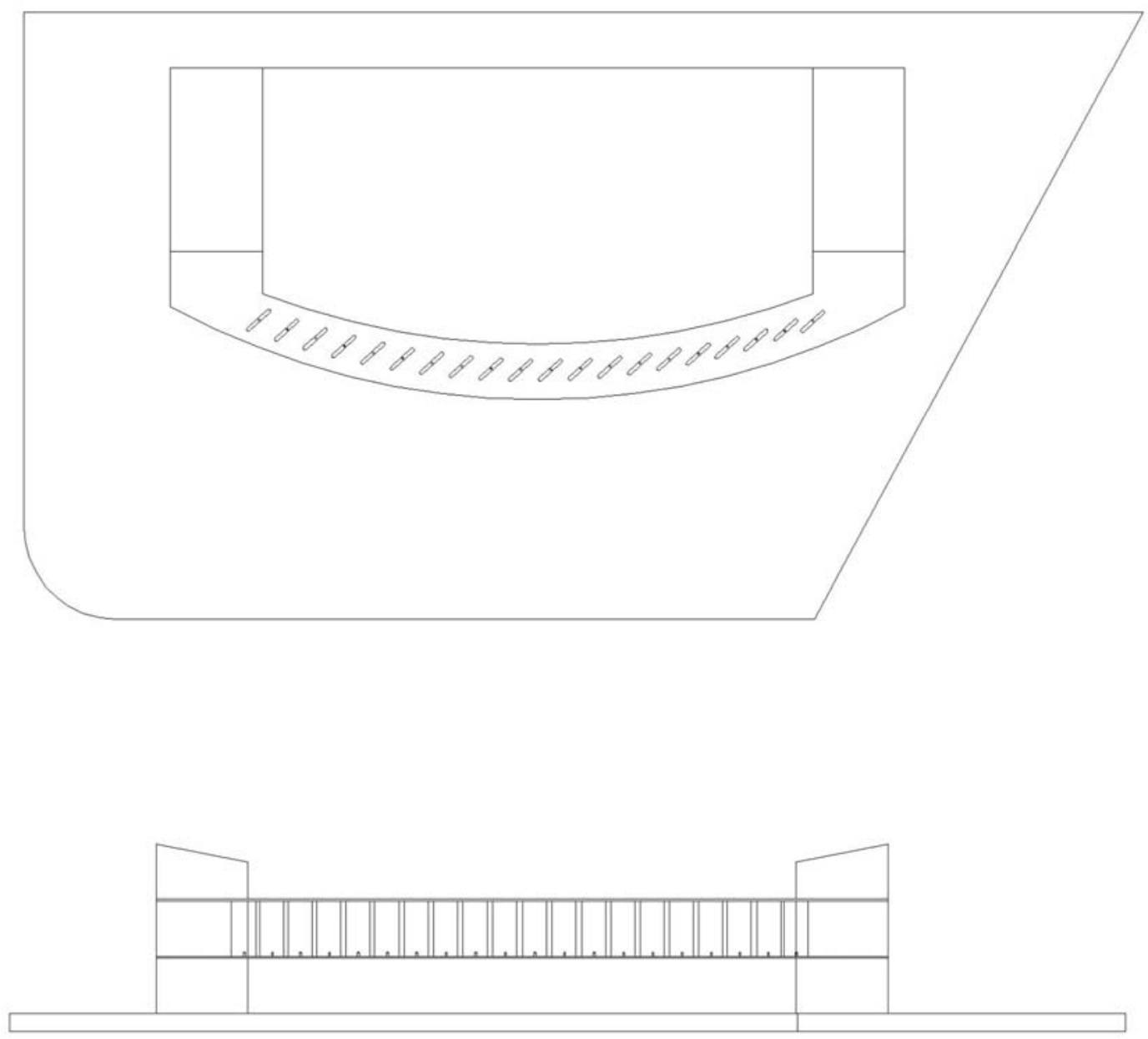

Desenhos elaborados por um dos alunos - 2004 

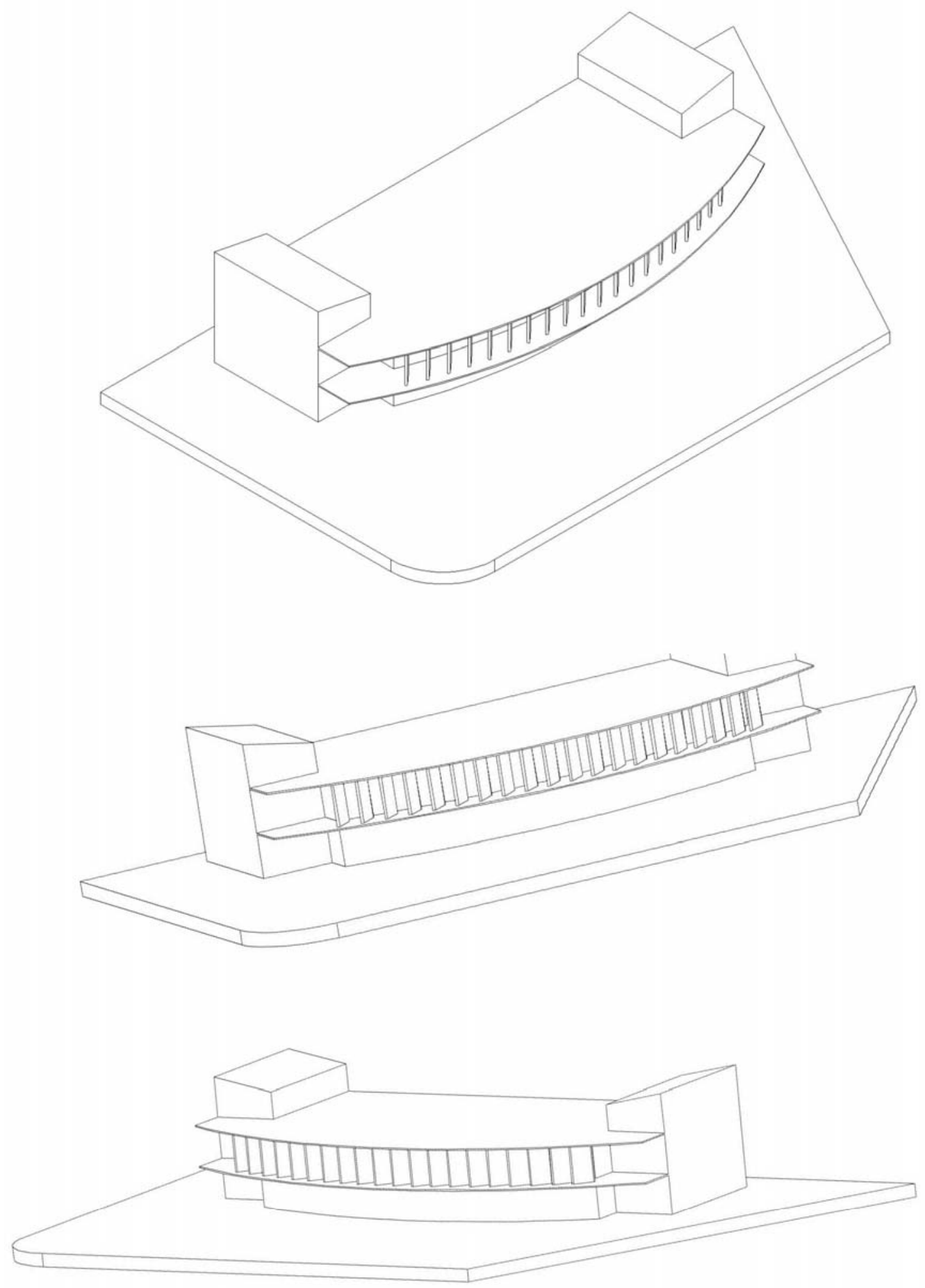

Desenhos elaborados por um dos alunos - 2004 


\section{Capítulo 04: VISÕES E DIVERGÊNCIAS}

Universidades Públicas

ENTREVISTAS COM PROFESSORES 


\section{I - ENTREV STAS COM PROFESSORES}

O ensino e a aprendizagem são atividades básicas e necessárias para o funcionamento de uma universidade. Para realizar este trabalho foi preciso registrar as idéias e o pensamento dos arquitetos-professores, assim como a forma com que estes profissionais se comprometem com a qualidade do ensino e com a formação dos seus alunos.

A constituição do trabalho aqui desenvolvido resulta de registros de caráter histórico indicando o posicionamento de cada arquiteto-professor por meio do seu discurso.

Acredita-se que este material devidamente registrado, enquanto forma de produção de conhecimento e forma de exercício profissional interessa a universidade de onde esses professores vieram. É um círculo que se fecha e que procura informar a atividades destes arquitetos-professores sob a forma de tese.

A captação de dados para esta tese optou pela realização de entrevistas e depoimentos dos arquitetos-professores. Os textos provenientes da gravação das entrevistas foram devidamente editados e sumarizados, e é importante que se mantenha assim acessível no âmbito dos acervos das bibliotecas da Faculdade de Arquitetura e Urbanismo da Universidade de São Paulo - FAUUSP.

Dessa forma 0 produto da presente pesquisa pretende estabelecer o debate sobre o ensino de projeto de edificações seja na própria Universidade de São Paulo - USP, assim como nas demais faculdades de arquiteturas particulares de São Paulo.

Foram discutidos dez temas referentes à constituição do ensino de projeto no primeiro ano da graduação:

1- Nível de formação dos alunos que cursaram o ensino médio;

2 - A expansão do número das Instituições de Ensino Superior no Curso de Arquitetura e Urbanismo;

3 - O Projeto Pedagógico e os Cursos de Arquitetura e Urbanismo;

4 - 0 conteúdo da disciplina de Projeto de Arquitetura 1;

5 - 0 mercado de trabalho e a formação do arquiteto;

6 - 0 arquiteto e o perfil profissiográfico;

7 - 0 ensino do desenho no primeiro ano da graduação;

8 - A presença da história nas aulas de Projeto; 
9 - Exercícios Projetuais envolvendo simulação;

10 - Carga Horária das disciplinas projetuais;

A decisão de partir para a produção de entrevistas, como forma de verificar detalhadamente os acontecimentos descritos pelos profissionais do ensino de projeto. São depoimentos singulares. Foram escolhidos dois professores de universidade pública e dois coordenadores de cursos de graduação em arquitetura em centros universitários particulares do estado de São Paulo. 0 resultado se mostrou interessante a ponto de incluir os trechos mais importantes, ocultando o nome da escola e enfocando até que ponto é possível a organização do curso introdutório de projeto.

Outro motivo que ocasionou o desenvolvimento desse trabalho foi, a partir de entrevistas assim que o foco deixou de ser sobre as influências dos modelos jesuítico, napoleônico e alemão de transmissão do conhecimento na universidade brasileira, a bibliografia se mostrou rara e pouco freqüente. Os trabalhos e referências mais atualizados eram os registros dos Seminários PROJETAR I e II. Ocorridos nos anos 2003 e 2005, o primeiro se tornou uma publicação organizada pelos professores Fernando Lara e Sonia Marques e possibilitou uma importante contribuição ao ensino projetual como um todo.

As entrevistas mostradas, a seguir, foram as primeiras da série e apresentam um certo tom coloquial onde o importante é a expressão do pensamento arquiteto-professor, abrindo espaço para o debate da arquitetura e do seu ensino. 


\section{RESENHA DA ENTREVISTA COM O ARQUITETO E PROFESSOR DR. SI EGBERT ZANETTI NI}

O arquiteto e professor Siegbert Zanettini é dono de uma experiência invejável por aliar a grande experiência no ensino de arquitetura à prática do projeto e da construção. Deste ponto de vista, a entrevista se tornou rica e densa, mesmo que todos os temas não tenham sido explorados amplamente como nas outras entrevistas.

Em quase quatro décadas como professor na FAUUSP, Zanettini ${ }^{62}$ esteve presente em todo o processo de ensino e nas atividades correlatas. A partir de 1972, também como professor responsável ou coordenador quando em cursos integrados a outras disciplinas do Departamento de Projeto. Obteve o doutorado em 1973, com a tese Habitação e Implicações no Processo de Industrialização sob a orientação do Dr. Nestor Goulart Reis Filho. Em 2001 tornou-se livre-docente na FAUUSP. Tem experiência na área de Arquitetura e Urbanismo com ênfase em Projeto de Arquitetura e Urbanismo. Um dos grandes arquitetos paulistas, a intenção deste trabalho foi revelar qual a idéia que ordenava os pensamentos expostos nas indagações feitas diante dos temas desenvolvidos.

Os assuntos debatidos denotam significativo grau de criatividade, intuição e sensibilidade, presentes tanto na sua obra como na prática do ensino.

Acerca da entrevista, Zanettini relata que devido a má formação dos estudantes que cursaram o Ensino Médio e a ausência da disciplina de Educação Artística, os alunos chegam à graduação com graves deficiências. Por esta razão, antes mesmo do professor explicitar 0 que é o projeto de arquitetura dentro da sala de aula, ele deve providenciar uma estrutura de ensino em que caiba uma complementação da formação artística destes alunos.

Sendo assim, durante primeiro ano da graduação o intuito da faculdade se volta para apresentar aos alunos os canais da sensibilização artística.

No início do curso é apresentada uma foto de uma implantação de um conjunto edificado. Nessa foto aérea não é possível a determinação de como são realmente os volumes, assim como não é possível a definição de

62 Disponível no site do currículo lattes:< http://lattes.cnpq.br/7316307175643290>. Acessado em 31/12/2008. 
quais linhas significam elementos cheios ou vazios. Dado esse exercício para os alunos, eles decidem como deve ser o volume geral do conjunto edificado.

É o primeiro contato do aluno com o objeto arquitetônico. Cabe ao aluno criar a volumetria geral. É nesse momento que o estudante tem de fato uma atividade criadora. Transformar essas linhas em um desenho técnico é outro desafio. Tomando como base a implantação distribuída, os alunos vão criar um novo desenho obedecendo às linhas gerais da matriz distribuída no início. São duas etapas, na primeira são definidas as linhas de contorno da edificação. Na segunda etapa são definidas as linhas das alturas dos vários volumes. As alturas são mostradas através dos desenhos de um corte longitudinal e de um corte transversal. No final dessas etapas, os alunos criam os volumes solicitados e conseguem as medidas equivalentes para a construção de uma maquete volumétrica do conjunto edificado.

É normal que durante a etapa final, o desenho da implantação seja uma releitura da imagem inicial em uma escala pré-determinada. É também o primeiro exercício das disciplinas integradas de uma faculdade pública. 0 resultado final é uma coleção de maquetes volumétricas das mais variadas cores mostrando a diversidade de formas e volumes que podem resultar de uma mesma implantação geral.

Esse exercício é importante porque revela o quanto o estudante conhece de desenho técnico. De acordo com a sua habilidade ele pode produzir uma variedade de volumes de maior ou menor significado.

Entretanto, é uma proposta de exercício que ao ser comentada com o professor Antonio Carlos Barossi provoca a seguinte reação: - não é arquitetura. Logo, a intenção deste exercício ${ }^{63}$ inicialmente se contrapõe a atitude de jogar 0 aluno de cabeça na arquitetura com toda a sua complexidade.

Seria esta a maneira mais apropriada de ministrar os primeiros ensinamentos? Deve-se propor aos alunos um exercício volumétrico ou um pequeno projeto?

\footnotetext{
${ }^{63}$ A autora participou durante o ano de 1997 como monitora e estagiária do P.A.E. juntamente com os professores Barossi e Zanettini.
} 


\section{RESENHA DA ENTREVISTA COM O ARQUI TETO E PROFESSOR DR. ANTONI O CARLOS BAROSSI}

A segunda entrevista foi feita com o professor e arquiteto Antonio Carlos Barossi ${ }^{64}$ que se formou pela FAUUSP em 1979. Possui doutorado em Estruturas Ambientais Urbanas, com a tese intitulada Ensino de Projeto na FAUUSP sob a orientação do Dr. J oaquim Manoel Guedes Sobrinho. Atualmente é professor na FAUUSP desde 1989 e completa este ano 20 anos de docência . É também professor na Escola da Cidade desde 2005. Tem experiência na área de Arquitetura e Urbanismo, com ênfase em projetos de edificações além de ser sócio-diretor do escritório Barossi e Nakamura Ltda.

Quando o professor Barossi alega não entender porque 0 conteúdo do curso de projeto arquitetônico deva ser diferente no primeiro ano, inicia-se uma discussão que pode suscitar diferentes idéias e atitudes. Ao mesmo tempo, ele instiga os professores a encontrar um tema e um terreno que soem como um desafio interessante para o aprendizado do ingressante: Pode ser qualquer tema adverte, mas o tema escolhido deverá fazer parte do processo de construção da cidade.

0 entrevistado enfatiza 0 desenvolvimento do projeto de arquitetura inserido em um contexto, ou melhor, fazendo parte de uma engrenagem maior que é a cidade.

Antonio Carlos Barossi, formado no final da década de 70, pela FAUUSP, apresenta um pensamento peculiar sobre o ensino de projeto. Segundo ele o ensino do primeiro ano deve ser igual ao dos anos seguintes e sempre a partir de exercícios projetuais. Além disso, a universidade tem de assimilar os alunos que apresentam falhas na sua formação, não como uma deficiência do sistema de ensino, mas sim como uma identidade, aplicando um olhar atento para as individualidades.

O entrevistado avisa que a escolha de temas para as disciplinas projetuais deverá estar inserida em uma rede de relações humanas, acadêmicas e sociais, pois afirma que só com o terreno isolado e o programa, 0 aprendizado não acontece.

Durante o tempo todo da entrevista, o professor Barossi chamou a atenção para a questão da cidade ao dizer que os temas de projeto tem que se relacionar com as questões urbanas e sociais. É importante apontar a

64 Disponível no site do currículo lattes: < http://lattes.cnpq.br/5940226903872726 $>$. Acessado em 31/12/2008. 
forte ligação entre as palavras projeto e cidade, e como esta relação foi destacada ao longo da conversa.

Outra afirmação ocorreu ao definir que o aprendizado do estudante se dá pelo trabalho, pelo exercício da intuição, pelo contato com os colegas e com os professores. Não há tempo para ensinar o aluno a utilizar o escalímetro ou como fazer os traços diferenciados no desenho, porque 0 professor tem que ensinar projeto, e não há tempo disponível para todos os detalhes.

Pensar em propor que as disciplinas sejam vinculadas é muito difícil, e quem tem que fazer a integração dos assuntos é o estudante.

Sobre a postura dos arquitetos recém-formados, Barossi relata que eles deixam a faculdade com um comprometimento maior com o Poder Público, e encerra, a entrevista, dizendo que seja qual for o projeto, pode ser 0 portão de uma casa, por mais singelo que seja, a sua existência interfere no processo de construção da cidade. 


\section{ENTREVI STA ${ }^{65}$ REALI ZADA COM O ARQUI TETO E PROFESSOR DR. SI GBERT ZANETTI NI}

- Sobre a experiência acadêmica:

- Começaria dizendo que a questão do ensino me preocupa desde 1974, quando comecei a dar aula na FAU, e sempre na área de projeto. Especialmente, dei aula nos segundos e terceiros anos, mas muito tempo e grande parte do tempo foi destinada aos alunos ingressantes. Ao longo do tempo, o que eu fui observando como estudioso do assunto, por que eu não só dava aula mais estudava, era a necessidade de ensinar o aluno a se envolver dentro do contexto do aprendizado.

- Sobre a atividade docente:

- Tínhamos inicialmente uma formação muito dogmática e acadêmica. Era exigido do aluno que ele reproduzisse aquilo que os professores pensavam. $O$ aluno só era considerado um bom aluno se, ele se esforçasse para alcançar a concepção do professor. Isso me parecia contraditório por que o aluno não possuía o universo cultural do professor. No máximo o aluno fazia um desenho ou alguma experiência volumétrica sem colocar um pouco da sua experiência no desenvolvimento do trabalho. $O$ professor dava um elemento semipronto ao aluno e o aluno teria que acabá-lo seguindo alguns padrões pertinentes à opinião do professor.

\section{- Sobre o Ensino Médio:}

- O ensino fundamental e o ensino médio eram muito ruins por que o setor de artes praticamente desapareceu da grade de ensino a partir da década de 70 . Eu achava que isso era uma parte da formação cultural não só do aluno de arquitetura, mas de qualquer área do conhecimento. $O$ setor de artes é fundamental na formação do aluno. o desenvolvimento artístico é tão importante como o desenvolvimento racional. Sem experimentar este desenvolvimento, os alunos não têm a capacidade de criar, de tomar iniciativas próprias. $O$ que acontece nas escolas e no caso específico dos alunos é que existe uma parte do cérebro que não é desenvolvida. Então, o aluno transforma-se em um reprodutor, e não um criador. $O$ aluno deixa de produzir e, não apenas na área específica de artes,

65 Entrevista realizada em Outubro de 2008. 
arquitetura e design, mas em todas as áreas do conhecimento. Nós não encontramos um engenheiro, um médico, um advogado ou um economista que tenha capacidade criadora.

É primordial a presença do ensino artístico dentro das escolas para que aconteça um equilíbrio entre o mundo sensível e o mundo racional. As áreas do conhecimento devem ser formadas com as ciências humanas, econômicas e ambientais, de forma que todas estejam extremamente integradas, produzindo um mundo único. Assim, toda vez que na produção humana as coisas não sejam entendidas de maneira integrada, a área do conhecimento é segmentada e torna-se fragmentada, parcelar. Isso acaba propiciando um ensino deficiente. Ou seja, o aluno tem uma formação deficiente, fraca, parcial e quase sempre direcionada ao racionalismo cartesiano. 


\section{ENTREVISTA ${ }^{66}$ REALIZADA COM O ARQUI TETO E PROFESSOR DR.ANTONIO CARLOS BAROSSI}

- Se partimos da premissa de que o aluno da faculdade privada teve um ensino médio com determinadas dificuldades, devem ser utilizadas algumas disciplinas do primeiro ano da graduação para complementar essas deficiências, como por exemplo, a ausência do ensino artístico no ensino médio?

- Não, eu não acho que estas disciplinas complementares devem existir, porque no ensino superior parte-se do pressuposto que não existe deficiência. Existem identidades diferentes, pessoas que são diferentes. Se uma pessoa chegou até o ensino superior, este curso pressupõe uma formação. É esta formação que a sociedade lhe ofereceu. Todos têm deficiências. Se for analisar friamente, cada um tem a sua deficiência ou dificuldade. $O$ fato da pessoa não ter tido ensino artístico no nível médio, constitui uma característica dela, e assim que deve ser encarada, não como uma deficiência. Eu acho que a formação artística deve vir dentro das disciplinas normais. Não acho que deva existir formação complementar. Não dá para padronizar, imaginar que todo mundo vai assimilar da mesma forma, que todos têm a mesma capacidade, as mesmas dificuldades. Isto leva a partir da premissa de que se as pessoas são diferentes, vão evoluir, (não vou nem dizer assimilar, porque não considero que a função do professor é transmitir pura e simplesmente), vão desenvolver as atividades de formas diferentes. Não acho que deve existir disciplina complementar. Temos é que ter um olhar atento para as individualidades.

- Como acha que deve ser o ensino de projeto no primeiro ano?

- Igual no segundo ano, no terceiro ano, no quarto ano e no quinto ano.

- E como deve ser então?

- A escola tem que instituir temas que digam respeito às questões urbanas, às questões sociais. I sto deve balizar todos os cursos. Eu acho que o ensino de projeto no primeiro, no segundo, no terceiro, no quarto e no quinto ano deve ser feito a partir de projetos. Fazer projetos. Mas quais projetos? Aí que está a questão. E como?

${ }^{66}$ Entrevista realizada em Dezembro de 2008. 
- Como o Sr. escolhe os temas? Terrenos possíveis ou virtuais?

- Isto depende muito do momento político, da circunstância da escola, da perspectiva dos professores. Não dá para generalizar. Não pode ser simulação. Quando o aluno faz um projeto, não importa o ano, ele tem que se sentir pertencendo a um processo. E este é o processo de construção da cidade. $O$ aluno tem que sentir que $o$ que ele está fazendo, de alguma forma, por mais sutil que seja, contribui para o processo de construção da cidade.

- O que o Sr. afirma que seja simulação?

- Simulação é quando você inventa do nada, alguma coisa, fingindo ser qualquer outra coisa.

- Projetar um escritório de arquitetura, seria simulação?

- Até um escritório de arquitetura pode fazer sentido. Depende da maneira como é colocado o terreno, das pessoas que você traz para falar sobre este assunto. Mas tem que conseguir fazer aquilo ser verdade. Não que vá ser construído, é lógico que não, não é esta a questão. Eu acho que não tinha que ter primeiro ano em projeto. (Não estou falando nem em história, nem em tecnologia. Estou chamando de tecnologia aquelas áreas do conhecimento que aqui na Faculdade A, dizem respeito ao Departamento de Tecnologia e ao Departamento de História. Pode ser que em outras escolas não tenham este nome. São disciplinas que realmente pressupõem um conhecimento a ser transmitido). Projeto é diferente. Projeto não tem conhecimento. E o aprendizado não se dá pela assimilação do conhecimento.

- O aprendizado se dá pela prática?

- Pelo trabalho, pelo exercício da intuição, pela instrumentação, pelo contato com os colegas, contato com os professores. Pela maneira que o trabalho é realizado. A escola deveria ter um conjunto de projetos sendo desenvolvidos ou a ser desenvolver, e $o$ aluno desde $o$ primeiro ano escolhe qual que ele quer fazer.

- Temas reais, efetivos?

- Não, isso não. Quando eu falo do aluno se sentir pertencendo, quer dizer sentir de alguma forma que aquele projeto que está sendo feito faz sentido e interfere. Não é pelo fato de ser projeto real. De jeito 
nenhum. Nem dá para ser projeto real, não tem como, pelo contrário. Os projetos têm que ser investigativos, utópicos. Por exemplo, este trabalho aqui (mostra o trabalho dependurado na parede do estúdio) é da optativa. É um projeto de equipamento público vertical, de determinado terreno da área central. Ele suscitou uma série de discussões que estava na ordem do dia da cidade. Por exemplo, esta disciplina teve o mesmo tema desenvolvido em outra escola fora do Brasil, nos Estados Unidos. Então, você arma uma série de relações onde o projeto faz parte. Só com o terreno, o programa e o projeto isolado não acontece 0 aprendizado. 0 projeto tem que estar inserido dentro de uma rede de relações humanas, relações acadêmicas, relações sociais, e aí ele se coloca. E estas relações variam conforme as circunstâncias históricas, conforme os alunos, conforme os professores, conforme cada uma das identidades. É difícil. Tem que ter uma tensão permanente. Não dá para encontrar uma estrutura que funcione sozinha, sem as pessoas, sem o momento, sem a história. Tudo tem que estar ligado. E isto cria surpresas, inclusive. Por isso não vejo diferença entre o ensino de projeto do primeiro ano, do segundo, enfim. Sinceramente, não. Aí as pessoas falam: Mas você vai dar um hospital para os alunos do primeiro ano? Por que não? Pode ser. De repente a gente arruma um jeito de fazer sentido isto, a partir do repertório que eles têm, ou que eles não tem. Pode ser sim. Eu não vejo que tenha mais ou menos complexidade, ou que isto implique em um aprendizado mais efetivo ou menos efetivo. É uma questão interessante.

- Nessa faculdade tem Projeto Pedagógico ou uma diretriz de projeto?

- Eu não sei se isto que eu vou dizer é propriamente um projeto pedagógico. $O$ que tem e que também é fruto das circunstâncias específicas aqui da nossa escola e dos professores que trabalham aqui. Conclui-se que deveria haver no âmbito das disciplinas obrigatórias três tipos de projetos a serem desenvolvidos. Ou três estúdios, como o pessoal vem chamando. No primeiro ano tem a AUP - 608 que é uma disciplina ministrada por professores de todo o departamento. É uma integrada. E eles dão pequenos trabalhos que tem ênfase em cada área. No segundo ano, é um projeto que aborda a infra-estrutura urbana. Tem pontes, passarelas, estações rodoviárias, ferroviárias, transposições diversas, enfim, toda a parte de infra- 
estrutura. Aí no terceiro ano é habitação e no quarto ano o tema é sobreequipamentos públicos. Esta é a seqüência. A forma de implementar estes projetos é como se faz em geral, definindo uma área que tem uma questão urbana forte, e propondo um tema e um programa dentro de cada um destes três temas. Os trabalhos são desenvolvidos em equipe com dois ou três alunos. $O$ que é uma pena. Tinha que ter algum momento em que o projeto deveria ser desenvolvido sozinho. São realizados seminários em grupos. Dividese a turma em grupos. Às vezes tem rodízio de professores, às vezes não. Varia conforme a disciplina. Em vez dos professores orientarem os trabalhos individualmente, a orientação é conjunta. Grupo de dez, cada um apresenta o seu projeto e aí o professor comenta os projetos em conjunto. A turma é dividida da seguinte forma, um professor fica com dez alunos, o outro também fica com dez. Às vezes tem rodízio de professores no final, no meio e no fim. Mas há sempre um seminário geral que é quando todos os professores participam, e os alunos apresentam um produto final (planta, corte, elevação). Tem os seminários intermediários que não é necessariamente o produto acabado, mas as discussões são em conjunto. Agora estamos intercalando algumas orientações individuais, por equipe. Esse é o sistema. O seminário geral da classe acontece quando o aluno apresenta. Não tem mais "entrega". Mas são produtos já formatados e algumas orientações individuais ao longo do semestre. Não sei se isso pode ser chamado de projeto pedagógico, mas é por aí.

- Como deve ser a disciplina referente à introdução do ensino de projeto Projeto 1 ?

- Agora eu não estou participando da disciplina do primeiro ano aqui na Faculdade A. Já participei. Ela pretende apresentar o projeto dentro de uma visão ampla. Por isso tem a participação de professores de todas as áreas: PV, DI, Planejamento, Projeto de Edificações e Paisagismo. Antigamente, cada um dos cinco grupos dava o seu curso separado. Era um curso de um ou dois dias por semana. Agora, a disciplina tem quatro dias por semana, e ao invés do aluno fazer o projeto em quatro meses, um dia por semana, ele faz em um mês, durante quatro dias por semana. Concentramos as disciplinas. Então começa com um projeto, depois um trabalho de Programação Visual, um de Desenho Industrial, depois vem um de 
Paisagismo. Continua mais ou menos a mesma coisa. A única diferença é que todos os professores orientam todos os projetos. Tem professor de projeto de edificações orientando DI, tem professor de DI orientando edificações. $O$ que muitas vezes é uma dificuldade. Tem professor que não consegue. Tem pessoas que trabalham com PV, que trabalham com arte, desenho, orientar projeto de edificações ou planejamento. É complicado. Eu não estou participando desta disciplina, não sei como dizer como superaram isto. I sto eu estou te contando da época em que eu participei, cinco anos atrás. Parece que evoluiu bastante. Precisa ir conversar com o Zanettini.

- O que o Sr. acha daquele exercício de transformar a implantação em maquete volumétrica?

- Eu não acho bom. Porque não é arquitetura. 0 aluno tem que entrar de cabeça na arquitetura já desde o primeiro dia. A arquitetura com toda a sua complexidade. A maquete volumétrica era um exercício plástico. Não tem uma questão urbana envolvida. É uma figura, uma imagem. É plástica, é um exercício técnico. Podia ser feito em Tecnologia (Departamento de Tecnologia). Não acho que isto é projeto. Eu acho que o aluno inicia projetando. E é lógico que nas outras disciplinas, em história, ele está estudando referências, em Tecnologia ele começa a ver materiais, etc.

- Como introduzir o ensino de desenho?

- Penso que não é ensinando a pegar na escala que o aluno vai aprender a usar a escala. Ele vai ver os trabalhos, vai ver as pessoas desenhando. Se ele estiver empenhado em aprender, ele vai descobrir os caminhos. Eu acho que os alunos aprendem mais entre si do que com o professor. Então se você consegue criar um contexto de produção dos alunos em que há uma troca, com seminário, com espaço, coisa que a Faculdade A favorece muito, o aluno acaba aprendendo. Se você conseguir fazer com que haja uma interação entre os alunos, eles aprendem. Agora, se você tem alunos que não sabem pegar na lapiseira: “ - Então, para tudo e vamos dar um curso de desenho". Não dá. Tem que ensinar projeto. Não estou relevando a carência. Mas acho que tem que ensinar projeto. Deve ter disciplina de desenho, de linguagem. Aliás, uma das propostas que fizemos aqui para a FAU, era, ter um "curso de desenho" (entre aspas), do começo 
ao fim do curso. Direto do primeiro ao último ano. Trataria de todas as linguagens em geral: desenho, programas de computador, photoshop, AutoCAD, fotografias, escultura, cinema. Ao longo deste período 0 aluno estaria aprendendo sempre, tendo aulas de linguagem e evoluindo.

- Integrando com o projeto de arquitetura?

- Não, de uma forma autônoma. É muito difícil você querer vincular. 0 projeto tem que ser autônomo, quem faz a integração é 0 aluno.

- Uma das inquietações com relação a uma divergência entre o ensino da universidade pública em comparação ao ensino efetuado na universidade privada é que a primeira pretende formar os arquitetos para a sociedade enquanto que a segunda forma arquitetos para o mercado de trabalho. 0 que o Sr. pensa disso?

- Penso que a Faculdade A prepara os alunos para o mercado, sim, só que eles adquirem uma visão diferente. Eles deixam a escola com um comprometimento maior com o poder público, dentro da atuação deles, qualquer que ela. Seja no âmbito público, ou no âmbito privado. São certos cuidados, certas questões que você se coloca ao fazer projetos que dizem respeito à questão pública. A maneira como o projeto insere na cidade, os reflexos, enfim, toda a interação do projeto com a cidade. Qualquer que seja o projeto. Pode ser o portão de uma casa, pode ser uma casa. Cada projeto por mais singelo que ele seja, ele tem um compromisso, pois ele constrói a cidade. Então, a formação da Faculdade A coloca esta questão para o aluno. Qual o papel do trabalho que ele está fazendo, sempre, seja ele qual for dentro do processo de formação da cidade. É só esta diferença, mas acho que eles são muito bem habilitados para o mercado. Ainda mais agora que eu vejo uma tendência generalizada de diversificar o conhecimento de todas as áreas de formação. Você vê o engenheiro querendo ensinar história e filosofia, percebendo o quanto isso é importante para o aprendizado da engenharia. Um aspecto característico da arquitetura é essa amplitude dos conhecimentos necessários. Ontem eu participei de uma banca de conclusão de curso dos alunos de engenharia ambiental, e a discussão era esta. As pessoas estão percebendo que a formação tem que ser diversificada. E a formação do arquiteto sempre foi diversificada, principalmente na 
Faculdade $A$, que tem todo este conjunto de profissionais das mais variadas áreas, dando aulas e participando. Mesmo que não sejam disciplinas específicas desta área do conhecimento, forma-se um caldo que favorece a participação no mercado. Eu acredito que a Faculdade A forma para o mercado, sim.

- Em sua opinião existem disciplinas que complementariam as aulas de projeto? Por exemplo, aulas de desenho?

- Para mim nem pensar. Fora de cogitação. Sou totalmente contra.

- 0 que o Sr. pensa exatamente?

- Eu penso que a universidade não tem que cumprir este papel e tem que assimilar os alunos que tem essas dificuldades, não como uma deficiência, mas como uma identidade. $E$ trabalhar isto no âmbito das disciplinas do curso superior. Não adianta querer assimilar um conhecimento que não foi adquirido. Mesmo porque assimilar conhecimento hoje em dia é a coisa mais fácil do mundo. Muito fácil.

- Qual é o perfil profissiográfico que a escola pretende para o aluno? É direcionado ao mercado? Como? Por quê?

- O que é o mercado? Por um acaso ele é independente da gente aqui na escola? Não, eu acho que a própria maneira como os alunos acabam se formando aqui dentro da Faculdade $A$, acabam interferindo no mercado também. Tem que pensar que a gente também faz 0 mercado. Não é direcionado. Não é assim: vamos ver o que o mercado está precisando, então vamos formar estas pessoas. 0 que acontece é que se a escola estiver afinada com a produção social dentro de uma perspectiva do que é melhor para a cidade, o que é melhor para as pessoas, você vai formar pessoas direcionadas para o mercado, só que com um perfil não específico. Porque o mercado é uma loucura. Ele muda de um ano para o outro. Dirigir uma formação universitária para o mercado, ainda mais em arquitetura é uma estupidez. Se você tiver que pensar em como vou interferir neste mercado. Já que ele é tão volúvel, ele pode estar sujeito a interferências da própria escola, em função das pessoas que vão se formando e ingressando neste mercado e vão criando demandas, e vão se inserindo e mudando as demandas. Eu não sei se isto é pretensão, mas o mercado é muito volúvel para montar um curso em 
função de um perfil para o mercado. I sto é uma loucura. Por outro lado ele é uma expressão da realidade social também.

- Sobre o início do curso de graduação:

- Eu acho que não tinha que existir esta idéia de primeiro ano. Uma hipótese para isso é justamente permitir que estes alunos se misturem com alunos mais velhos, coisa que eles fazem naturalmente. Isto poderia ser instituído, podendo ser até incorporado pela estrutura de ensino. Ninguém concorda comigo. Eu cheguei a essa conclusão dando aula no primeiro, segundo, terceiro quarto e quinto ano. Não tem diferença. Os trabalhos são semelhantes, os problemas são os mesmos. A busca dos alunos por instrumentos, por referências, é semelhante. Estou falando em projeto de edificações.

- Sobre aulas teóricas nas disciplinas projetuais:

- Eu antigamente achava que não. Acho que isso depende do perfil do professor. Quais são as referências que dizem respeito aquilo que você está produzindo? Acho que cabe aula teórica. Não existe um método, mas eu posso mostrar aos alunos um método possível. Pode existir pontualmente e circunstancialmente. Eu não acho que isto é uma questão que deve estar na estrutura do curso. 0 professor tem que avaliar isso em função do que está sendo produzido pelos alunos. Aí em cima disso o professor atua. Se for só para acompanhar os trabalhos, dando atendimento, orientação. Ou fazer só seminário, sem orientação, só os deixando trabalhar sozinhos.

- Sobre o estudante do primeiro ano:

- Não. Todo mundo acha que o primeiro ano tem ter que um tratamento diferenciado. Eu não acho. Cada vez mais, eu não acho. Talvez há vinte anos atrás, fosse diferente. Mas hoje, eu fico surpreso de ver, não sei se é uma característica da Faculdade $A$, mas a capacidade de superação que os alunos do primeiro ano têm. Teve uma história que aconteceu aqui que me levou a pensar dessa forma. Nós fizemos durante um tempo o Projeto Inicial, que era um projeto que era dado no início do ano onde todos os alunos da faculdade participavam. Como não teve concordância dos outros departamentos, só participavam os alunos das disciplinas de projeto 
durante duas ou três semanas. É um trabalho relâmpago. É escolhido um tema instigante, emblemático, um tema urbano. E o projeto é feito sem orientação. Há palestras significativas relacionadas ao assunto, tem indicação de bibliografia, tem base de dados elaborada, tem todo o suporte para produção do trabalho. Todos os alunos fazem. E o meu sonho era que os alunos do primeiro ano participassem deste processo também. Era um acontecimento que podia servir para inaugurar o ano, a escola inteira envolvida. Mas não deu, porque no primeiro ano os alunos fazem as disciplinas integradas, que são ministradas durante todos os dias. Não daria para eles participarem, a não ser que eles abrissem mão de três semanas de aula. Como a integrada é uma disciplina toda amarrada, não há essa flexibilidade. Só que o tema era tão legal que alguns alunos do primeiro ano se mobilizaram e queriam participar. Eles resolveram faltar nas primeiras aulas. Eles podiam faltar, porque eles precisavam ter no mínimo $\mathbf{7 0} \%$ de presença. Se eles quisessem faltar os outros $30 \%$, o problema era deles. Certos professores ficaram meio bravos. Aí um professor me disse que os alunos do primeiro ano não podiam participar do Projeto I nicial. Eu disse que eles não precisavam fazer porque não era obrigatório, mas se eles quisessem fazer, eles poderiam. - "Eles são adultos e fazem o que eles querem". Aí o professor reclamou e disse:- “Não, eles não podem fazer porque eles são crianças". O problema não foi a desconsideração que este professor teve com os alunos, de achar que eles eram crianças. I sso é o de menos, isso é bobagem. 0 problema de tratar os alunos como crianças, faz com que eles sejam crianças. Se eles não eram, eles vão ser. Eu acho que o contrário também é verdadeiro. Se tratar o aluno não como criança, mas como adulto, se ele não for adulto, ele vai ficar. Tratar o aluno como criança, o faz virar criança. E se eu tratá-lo como um adulto, ele irá se comportar como adulto. Então é uma relação dialética, que é importante. Potencialmente, existe condição para um professor olhar para o aluno como uma pessoa capaz, responsável.

\section{- Sobre referências:}

- Tem uma frase do Artigas que diz mais ou menos assim: "precisamos lutar contra os professores que dizem que os alunos do primeiro ano tem que ser tratados de modo diferente, dando só 
matérias simples, como se eles não pudessem pensar a cidade, não pudessem fazer projetos complexos".

- Sobre exercícios projetuais:

- Tem uma visão de se deve trabalhar com aquilo que é familiar ao aluno do primeiro ano. Por isso aquela idéia de fazer o desenho da própria casa. Tem que partir para o mundo. Tem que ir para a cidade. A questão é que 0 aluno está ansioso por um novo universo. $O$ aluno entrou na universidade que é um mundo novo que vai se abrir. 0 professor tem que propiciar isto. Não fechar, mandando o aluno trabalhar dentro da própria casa. Sou totalmente contra. Já fui a favor por ingenuidade. A minha tese, eu comecei com essa ingenuidade de buscar uma pedagogia, de buscar uma didática, como dar aula de projeto. Depois eu percebi que isto era impossível. Ficar preocupado justamente com as deficiências, tentar facilitar as coisas. Outro dia um professor criticou outro, porque ele usou no primeiro ano um termo que o aluno ainda não conhecia. E daí? Eu vou falar só o que o aluno conhece? I sso é uma insanidade. Eu não acho. Tem que falar de tudo, falar da transparência do espaço, de tudo. Ele pode não entender o que é na hora. Mas o curso não é para propiciar um entendimento instantâneo. À vezes uma frase desta pode entrar profundamente na cabeça do aluno, do que ficar falando só de coisas que ele conhece. Do jeito que 0 cérebro processa estes conhecimentos, é muito complexo. Eu tenho certeza que uma palavra que não faz parte do repertório, cria um ruído, que na hora que o aluno entender aquilo, vai ser muito mais profundo. Falar de modulação, falar de tudo. Eu aprendi isso com um professor aqui da Faculdade A, que era um pouco difícil. Ele tratava os alunos do primeiro ano como se ele estivesse falando com o Oscar Niemeyer. Ele fazia críticas sob o ponto de vista da qualidade plástica. Eu acho que ele exagerava um pouco. Mas em princípio como atitude, acho que ele estava correto. Eu devo tratar o aluno como arquiteto que está fazendo um projeto. Eu vou olhar o desenho dele, e dizer aquilo que é verdade. Se for ruim, se for bom, se tem tal problema, se não tem. Não tem que ter atenuante.

- Sobre questões urbanas pendentes: 
- Tem a cidade. E tem as questões que estão sendo discutidas em relação à construção da cidade. Por exemplo, tem o Zoneamento, tem o centro da cidade, tem a ponte estaiada, tem a questão da poluição dos rios, tem o projeto "Nova Luz", enfim, tem uma série de questões que estão sendo discutidas na cidade, e que particularmente na Faculdade A, estão sendo trabalhadas, nos grupos de pesquisa, nas palestras dos professores, nas publicações que estão sendo feitas. Então o tema que for dado para o aluno do primeiro ano, de alguma forma, tem que estar vinculado a tudo isto. Na FAUUSP é mais fácil fazer isto, porque o universo é muito grande.

- Sobre temas ministrados em escolas particulares:

- Na Faculdade C, o pessoal trabalhou a área do "Minhocão", que na época despertava muita discussão. Os alunos ficavam "pilhados". I sto estimula 0 aprendizado. $O$ aluno se sente pertencendo a um processo. Quando eu falo em pertencimento, e estar dentro de um contexto, é isto que eu quero dizer .

- Sobre a situação: o cliente é o professor e o arquiteto é o aluno:

- Isto nunca vai ser possível. Ele não é profissional. Eu vou tratar como se fosse, mas ele não é. Ele não vai fazer uma casa, não vai fazer uma obra para ser construída. $O$ objetivo não é este. Diferentemente de um arquiteto. Por isto a situação é importante. E o contexto que eu falo não é só a cidade. Não são só as questões sociais, as questões urbanísticas. Os professores que estão ali, o tipo de aluno que está lá, o que o aluno sabe das características. Tudo isto faz parte deste contexto que pode determinar que projeto nós vamos fazer e como. 


\section{Capítulo 05: VISÕES E DIVERGÊNCIAS}

Universidades Privadas

ENTREVISTAS COM COORDENADORES DE CURSO DE GRADUAÇÃO 


\section{I - ENTREVISTAS COM OS COORDENADORES DE CURSO DE GRADUAÇÃO}

Dando continuidade a sua visão de como deve ser o ensino de projeto no primeiro ano, cada entrevistado mostrou a sua posição com relação ao conteúdo da disciplina de ensino de arquitetura.

Da série de entrevistas iniciada e apresentada no capítulo 05, a continuação e a terceira entrevistada é a arquiteta e professora Paula Katakura ${ }^{67}$ que possui graduação em Arquitetura e Urbanismo pela Universidade de São Paulo (1984), mestrado em Estruturas Ambientais Urbanas pela Faculdade de Arquitetura e Urbanismo- USP (1997) e doutorado em Estruturas Ambientais Urbanas pela Faculdade de Arquitetura e Urbanismo- USP (2003). É coordenadora do Curso de Arquitetura e Urbanismo da FAAM (Faculdade de Artes Alcântara Machado) desde 2003 e foi diretora do Curso de Arquitetura e Urbanismo e Design da UNIBAN de 2000 a 2002. É sócia-gerente da VISART Criações Gráficas. Tem experiência na área de Arquitetura e Urbanismo, com ênfase em projetos de edificações e sinalização de equipamentos urbanos ligados ao transporte público.

A quarta e última entrevista foi feita com o arquiteto e professor Carlos Eduardo Zahn ${ }^{68}$ que possui graduação em Arquitetura e Urbanismo pela Universidade de São Paulo (1966), mestrado em Arquitetura e Urbanismo pela Universidade de São Paulo (1979) e doutorado em Arquitetura e Urbanismo pela Universidade de São Paulo (1989). Foi coordenador do curso de Arquitetura e Urbanismo no Centro Universidade Nove de Julho por exatos dez anos. Atualmente é professor do Curso de Arquitetura e Urbanismo do Centro Universitário Nove de Julho e professor doutor da Universidade de São Paulo. Tem experiência na área de Arquitetura e Urbanismo, com ênfase em Planejamento e Projeto do Espaço Urbano, atuando principalmente nos seguintes temas: planejamento urbano, urbanismo, equipamento urbano, planejamento urbano e regional e identidade urbana.

\footnotetext{
${ }^{67}$ Disponível no site do currículo lattes: < http://lattes.cnpq.br/2452739652818239 > Acessado em 31/12/2008.

${ }^{68}$ Disponível no site do currículo lattes:<http://lattes.cnpq.br/2000837218202247 > Acessado em 31/12/2008.
} 


\section{RESENHA DA ENTREVI STA COM A COORDENADORA DE CURSO DE GRADUAÇÃO DRA PAULA KATAKURA}

A postura da professora Paula Katakura é coerente ao afirmar de que não se deve ensinar projeto aos estudantes antes deles terem noção de desenho técnico. Por esta razão durante os primeiros semestres são ministradas duas aulas de desenho técnico por semana. Mas mesmo assim, as disciplinas de desenho e projeto arquitetônico são apenas vinculadas, e não constituem uma integração efetiva.

Com respeito ao problema relacionado ao nível do Ensino Médio em geral, e em como os alunos tem chegado despreparados para o Ensino Superior, a saída, segundo ela é colocar as disciplinas básicas dentro das disciplinas específicas. Disciplinas básicas de complementação como língua portuguesa, matemática e física, se colocadas na grade desde o início do curso podem provocar um certo grau de evasão, porque o aluno tem urgência em conhecer o universo da futura profissão.

A professora e atual coordenadora relata ser comum o aluno entrar na faculdade sem saber que é preciso desenhar. Alguns alunos acreditam que desenhar no computador é suficiente e que não é necessário aprender a desenhar com lápis e papel, além de ter que respeitar as normas de desenho. Parece haver dentro daquela faculdade um consenso de que é necessário saber desenhar para que o estudante possa expressar o seu pensamento assim como representar o que estiver projetando.

Perguntada a respeito se concorda com o exercício em que o estudante é obrigado a fazer a leitura e o desenho da própria casa, Paula responde de forma categórica que o aprendizado do desenho de reprodução da casa do estudante não pode servir como referência, a não ser que sejam identificados os problemas e imediatamente corrigidos.

Sobre o exercício criado pelo professor Zanettini e aplicado no início do curso de projeto, a professora alega que o fato de ser adaptado um programa após a definição das formas denota um equívoco. 0 programa deve estar ligado a um determinado uso, e isso é o princípio para projetar formas adequadas.

É interessante a descrição do funcionamento do Laboratório de Arquitetura e de Urbanismo, onde ocorre uma integração vertical entre os estudantes desde o primeiro até o sexto semestre. É uma experiência que deveria ser divulgada e debatida entre os outros cursos, para o entendimento da sua eficiência e realização. Assim como, resultados obtidos com a implantação do escritório-modelo. 
Em outra questão, a Dra. Paula foi bastante convicta: - sem o aluno saber a desenhar não se deve ensinar projeto . 0 intuito dos primeiros semestres deve ser a aquisição de um repertório de arquiteturas exemplares. A transmissão de conhecimento do que é projeto de arquitetura deve ser feita através das próprias obras de arquitetura, pesquisadas ou apresentadas.

E finaliza confiante: - Eu acredito que o projeto pode ser ensinado. 


\section{RESENHA DA ENTREVI STA COM O ARQUI TETO E PROFESSOR DR. CARLOS EDUARDO ZAHN}

O professor e arquiteto Carlos Zahn iniciou a conversa relatando que o grande problema em relação à formação que os estudantes obtêm no Ensino Médio, tanto no ensino privado como no ensino público é a ausência de informações sobre geometria descritiva. O futuro arquiteto necessita conhecer e saber trabalhar com a geometria descritiva, além de possuir conhecimento acerca dos valores artísticos em geral.

Segundo conta o arquiteto e professor Miguel Pereira ${ }^{69}$, essa preocupação é legítima desde os tempos de Vitruvius, que advertia :

Deixe-o (o arquiteto) ser educado, competente com o lápis, instruído em geometria, saber muito história, ter seguido os filósofos com atenção, entender a música, ter algum conhecimento de medicina, conhecer a opinião dos juristas, e estar acostumado com a astronomia e a teoria dos céus.

No entanto, Zahn ressalta que não só é a formação artística que vem deficiente do Ensino Médio. 0 ensino de Língua Portuguesa também tem piorado muito, e os estudantes estão escrevendo e falando muito mal. Este aspecto também precisa ser enfrentado, e não é à toa que o estudante durante o primeiro semestre da faculdade é obrigado a cursar a disciplina de LPT (Leitura e Produção Textual).

Sobre o ensino de projeto no primeiro ano, o professor alega que o estudante deve primeiramente entender o que significa projetar. Dada essa informação, o estudante deve ser submetido a uma espécie de imersão no universo da arquitetura por meio da explicação e pesquisa de arquiteturas exemplares, ou referências, como se costuma dizer.

O professor Zahn é categórico ao afirmar que durante o curso de Projeto Arquitetônico 1, não dá para sair projetando, porque muitos estudantes não entendem ainda o que é projetar. Este aprendizado deve ser feito através da transmissão do conhecimento do que é arquitetura, que pode ser efetuado através de pesquisas autodidatas, visitas e aulas expositivas. Assim que o estudante tiver noções de arquitetura e entender como se projeta, ele estará pronto para realizar o primeiro projeto.

${ }^{69}$ Citação comentada pelo professor Miguel Pereira no prefácio de Pessoa (2006, p. 12). 
Quanto ao ensino do projeto de arquitetura desenvolvido durante as oito disciplinas presentes na grade da Faculdade onde atualmente leciona, 0 professor está de acordo com o fato deste curso se apresentar com um caráter diversificado.

Após aproximadamente dez anos da existência do curso, Zahn afirma que a universidade tem que oferecer oportunidades para o estudante optar em trabalhar entre as áreas ligadas ao urbanismo, ao projeto de edificações, aos projetos de equipamentos públicos, design e até comunicação visual.

No tocante ao projeto de edificações, ao ensinar projeto, 0 professor Zahn destaca que há uma preocupação em despertar no estudante a intenção plástica, que é como o projeto arquitetônico deve se expressar através de uma preocupação relacionada à forma e ao volume da edificação 


\section{ENTREVISTA ${ }^{70}$ COM A COORDENADORA DE CURSO DE GRADUAÇÃO E ARQUITETA DRA. PAULA KATAKURA}

- Se partimos da premissa de que o aluno da faculdade privada teve um ensino médio com determinadas dificuldades, devem-se utilizar algumas matérias do primeiro ano da graduação para complementar essas deficiências, como por exemplo, a ausência do ensino artístico no ensino médio?

- Existem duas coisas: uma é que mesmo na escola pública hoje, você tem alunos com nível diferente do que há 20 ou 30 anos atrás. Também nas escolas públicas o aluno chega menos preparado. É lógico e comparativamente vai chegar menos preparado do que uma elite que consegue acessar a universidade pública.

- Existe a necessidade de suprir, ou mesmo fazer um nivelamento, uma reparação na área artística?

- Este é outro problema. Na verdade a disciplina de Educação Artística saiu do currículo das escolas públicas por um tempo e agora retornou. E também com a carga horária mínima que o MEC exige ( 3600 hs.) é muito difícil colocar uma complementação, tanto da área artística quanto de matemática, de física, de português, que também seriam necessárias. São disciplinas que a gente acaba tendo que colocar como atividades complementares, para o aluno cursar a parte, como reforço, porque a grade é muito enxuta e não cabem dentro dela muitas disciplinas básicas. Antigamente a Faculdade de Engenharia tinha alguns semestres básicos e depois os alunos tinham direito a escolher as engenharias. Eles faziam um curso inicial básico, mas parece que mudou de novo. Isto preenchia a grade do início da graduação com muitas disciplinas básicas. A engenharia ainda é bastante árdua nesse sentido, porque ainda têm muito cálculo, muitas disciplinas de física, matérias de fundamentação. I sso acabava gerando uma evasão muito grande, porque os alunos que iniciam a universidade esperam já ter uma idéia do que é a profissão. Se demorar muito nas disciplinas de fundamentação eles perdem o ânimo. $O$ professor Guedes dizia que a Faculdade de Arquitetura presta um desserviço porque o aluno entra com muito ânimo no primeiro semestre, e quando ele sai, ele não tem mais aquele pique, aquele entusiasmo. Não que nas escolas particulares não aconteça

${ }^{70}$ Entrevista realizada em Novembro de 2008. 
isso. Pode acontecer. Mas o que contribui para isto é preencher a grade com muitas disciplinas básicas. A saída para minimizar isso é ir colocando dentro de outras disciplinas questões e exercícios que estejam ligados a forma, a geometria, aos elementos artísticos. Mas tudo aplicado dentro de outras disciplinas. Português, matemática e outras, a gente não consegue colocar na grade, porque as disciplinas específicas ficariam prejudicadas em função disto. Então, aqui, a matemática é aplicada dentro da tecnologia, plástica é aplicada dentro da disciplina de projeto, e assim por diante. Mesmo nas aulas de história orientamos o professor a trabalhar desenhos e croquis com o aluno nas aulas. Assim, além dele ter que ler e escrever, ele faz análises das edificações, das cidades, etc. Tudo isso para suprir, porque ele vem com uma formação insuficiente e ruim em todos os sentidos de Língua Portuguesa, Geometria, Matemática e outras. Não é só Educação Artística. Muitas vezes o aluno entra no curso de arquitetura sem saber que ele tem que desenhar. $\mathrm{E}$ a presença do computador acaba agravando esta situação. 0 aluno tem a ilusão de que está desenhando, mas na verdade os desenhos elaborados no computador não estão seguindo as normas de desenho, de representação técnica. Eu tenho visto vários currículos onde se coloca o curso de informática ou AutoCAD no primeiro semestre. Eu acho um erro. Primeiro o aluno precisa aprender a desenhar, a representar 0 que ele está observando e depois ir para uma ferramenta mais avançada como o computador. $O$ desenho, o croqui e a perspectiva têm que continuar fazendo parte do repertório. Aí o aluno vem com 0 laptop e mostra para o professor o projeto no computador. Só que ele ainda não aprendeu ainda a desenhar e representar. Quando o projeto é plotado, aí nota-se que ele não sabe desenhar. Fica um desenho sem definição de linha, não há diferença entre os objetos que estão na frente e os que estão atrás, enfim, o aluno não sabe o que está representando.

- Quais as disciplinas que são passíveis dessa adaptação?

- Sobra muito pouco tempo para colocar disciplinas de nivelamento. Precisa existir sim, só que elas podem estar dentro das atividades complementares dentro do contexto que o MEC hoje nos dá. Não é o ideal. Na verdade estamos trabalhando com o mínimo do mínimo. A carga horária é de $\mathbf{3 . 6 0 0}$ horas cheias. Se você for contar em horas de 
50 minutos, a nossa escola chega a 4350 horas em horas de 50 minutos. Existe uma resolução do MEC que diz claramente que uma hora-aula praticada por aí é a hora exigida pelo sindicato dos professores, para fins de remuneração, e não para cumprimento da carga horária mínima estipulada para os cursos. Todos os cursos devem ter no mínimo 3.600 horas. São 3.600 horas de 60 minutos, depois multiplicando por 50 minutos chega a 4320 horas. Nem todas as escolas estão cumprindo isso. Muitas estão mascarando, e ainda estão reduzindo. Normalmente, a carga horária do curso noturno é das $19 \mathrm{~h} 00 \mathrm{~min}$ horas até as $\mathbf{2 2} \mathrm{h} 30 \mathrm{~min}$ horas. I sto não dá quatro horas de 60 minutos. São 4 horas-aula de 50 minutos. Sem aula aos sábados. A carga horária por semestre é de $\mathbf{4 0 0}$ horas.

- Como era o curso de projeto do primeiro ano? Eu sei que você trabalhava como coordenadora daquela faculdade. Podia aproveitar e explicar como era o curso lá também?

- Lá na faculdade antes de sair, a gente ainda conseguia discutir qualidade. Depois virou um ensino de massa, parou-se de discutir, inclusive, nem coordenadores arquitetos o curso tem hoje. Não dá para discutir projeto em escolas assim. Antigamente, havia lá professores com o Dr. Francisco Segnini, que era da FAUUSP. Existia liberdade para discutir o projeto pedagógico, sim. Dava para estabelecer o que era projeto, o que era cada etapa, cada tema. Eram trabalhados alguns objetivos por semestre. 0 curso era anual, diferente, e acho que é assim até hoje. Aqui o curso é semestral e no primeiro semestre determinamos o que deverá ser trabalhado. Basicamente, era ensinada muita leitura de projeto, enquanto $o$ aluno estava aprendendo a desenhar. $O$ aluno precisa aprender um pouco de desenho técnico para fazer os seus primeiros projetos ou os seus primeiros registros. Mesmo que fossem leituras, reproduções de outros projetos ou de edificações existentes. Então, no primeiro semestre é dado um incentivo para a organização das formas, compreensão da cidade, leitura das edificações. Assim, quando o aluno começasse a aprender os primeiros traços de uma planta, um corte ou uma elevação, eram pedidos projetos pequenos e muito simples (sem programas complexos), onde o pequeno programa incentivava o exercício da forma. Segundo o nosso objetivo, no primeiro semestre não se trabalhava programa complexo. Já no 
segundo semestre do primeiro ano, o aluno devia trabalhar um pequeno projeto com um programa bem simples. Às vezes era dado um terreno existente, outras vezes era dado um terreno virtual. Eram vários exercícios. No início a gente trabalhava muito com terrenos virtuais, e depois passávamos para o terreno existente. I sso era dado ao mesmo tempo com as disciplinas de urbanismo, presentes do primeiro ao nono semestre. No primeiro semestre a disciplina de urbanismo trabalhava a leitura da cidade, a compreensão das hierarquias das ruas ao mesmo tempo em que a disciplina de projeto trabalhava com a leitura da edificação.

Lá na faculdade também, encontrávamos algumas resistências, porque tinha muito professor que trabalhava este exercício de pegar uma planta de uma implantação, e criar as formas. Eu acho interessante este exercício que começou com o professor Zanettini lá na faculdade pública. $O$ exercício foi baseado em outro exercício do Artigas. Qual foi o erro? Inventaram de colocar um programa depois de definida a forma da edificação. Depois de pronta a forma, era dado um programa para o aluno e dizia-se qual era o uso da edificação, por exemplo, um centro cultural. Era dado um programa arquitetônico para que 0 aluno por meio daquelas formas criadas inventasse as plantas. Aí que surgia o problema. Acredito que o programa precisa estar ligado a um uso, uma determinada forma, espaços diferenciados, alturas diferentes. É difícil colocar uma planta dentro de uma forma já criada. Este foi um desvirtuamento que aconteceu nesse exercício. Tem também aquele exercício da casa-cubo.

\section{- Você podia relatar esse exercício?}

- Logo ao entrar naquela faculdade, o que era feito no primeiro semestre era chamado de Casa-Cubo. Depois que nós entramos, acabamos pedindo para mudar. Eram dadas as seguintes dimensões: uma largura de 6 metros por um comprimento de 6 metros e por uma altura de 6 metros (um cubo). Esse cubo era dividido em dois andares, onde era feito um arranjo (uma planta). E lá dentro da faculdade os alunos criavam um espaço de 1:1(uma maquete), para o aluno sentir o espaço que estava sendo criado. Era interessante, mas para mim parecia espaço de cortiço sem projeto. Acho que é um mau exemplo de utilização do espaço. I nicialmente, este exercício poderia servir para sentir o que é um pé direito de 3 metros. Poderia ser 
interessante, mas acho que não era necessário executá-lo para a percepção da forma. Isto porque a ocupação deste espaço como projeto era muito pobre.

- Você acha que este exercício poderia ser dado em uma disciplina de projeto $1 ?$

- Eu acho que depois do primeiro ano não se brinca mais com este tipo de tema para projeto. No primeiro ano ainda cabe, mas na verdade eu não gosto muito desse exercício. As escolas já pararam de aplicar este exercício da casa-cubo. Já passou a fase desse exercício. Mas, ainda fazem o exercício de formas a partir de uma planta. Acredito que o problema é que esse exercício também desvirtua a idéia do que é um programa arquitetônico. $O$ programa não nasce para ser colocado dentro de uma forma já concebida, mas sim para crescer junto com a consideração dos materiais, dos pés-direitos, da implantação, etc. A casa-cubo, por exemplo, muitas vezes não tinha relação com o espaço onde era implantada. Não tinha terreno real, o espaço aonde ela era edificada era um terreno todo plano. É um exercício que poderia ser dado durante duas semanas. Agora, durante o semestre inteiro, é muita perda de tempo. Aqui, no primeiro semestre a gente tem muita leitura. Ao mesmo tempo, os alunos têm duas aulas de desenho por semana, onde aprendem a fazer corte e elevação. As duas disciplinas, projeto e desenho, precisam estar muito sintonizadas. Não integradas, mas o professor de projeto precisa estar sabendo o que os alunos estão aprendendo em desenho arquitetônico para aproveitar e aplicar na disciplina de projeto. No primeiro semestre os alunos fazem muita leitura da cidade, das edificações, fazem também grandes cortes, elevações, perspectivas, etc. Depois, no segundo semestre eles fazem uma pequena proposta já com terreno e são cobrados vários exercícios. Propor um exercício único para ser avaliado no final do semestre, era o grande erro daquela faculdade. Agora não, os exercícios são subdivididos, mudou muito. Há 20 ou 30 anos atrás, era um projeto único para o semestre inteiro. Não existiam etapas intermediárias muito definidas e daí o aluno começava a perder o fio da meada. Então aqui, fazemos etapas muito claras: levantamento, estudo de casos. A maioria não sabe fazer e pega todos os dados na internet. As referências das revistas são muito pobres, às vezes não tem implantação, falta norte. É difícil 
para o aluno se basear nestes periódicos para fazer os estudos de casos. A maioria só tem informação gráfica e fotos. Difícil quando aparecem plantas, cortes e elevações completas que permitam o entendimento de todos os pavimentos e do conjunto da edificação. Então, o estudo de caso é ensinado, principalmente, para o aluno aprender como se disseca uma edificação para poder projetar. São feitos no primeiro semestre pequenos exercícios que estimulam a percepção, a leitura das edificações existentes, assim como a ocupação de cada espaço. Eu também não gosto do exercício que muitos professores aplicam da leitura da própria casa. A leitura e o desenho de reprodução da casa do aluno também não são referências. Muitas vezes as escadas não têm dimensões corretas porque anexos e reformas são feitas. Logo, a referência da própria casa como registro rápido é até interessante, mas desde que sejam observados os problemas. Teve um aluno que uma vez apresentou o desenho da própria casa, onde para chegar até a casa, ele passava por diversos cômodos de outras famílias. I sto não é referência para os alunos de um curso de graduação.

- Como foi conduzido o Projeto Pedagógico desta faculdade diante dessa realidade e em que época?

- Aqui nós já tivemos muitos Projetos Pedagógicos. Na verdade, o projeto pedagógico de cada instituição precisa ser renovado a cada ano. No final de cada semestre a gente faz uma reunião com os professores porque eles precisam participar da elaboração do Projeto. Nesses últimos dez anos, houve muita alteração relacionada à legislação do MEC. A cada portaria, cada resolução, sai uma nova diretriz curricular, e nós somos obrigados a fazer uma revisão do projeto pedagógico. Tivemos redução da carga horária em função das possibilidades que o MEC deu. Nas $\mathbf{3 . 6 0 0}$ horas, a gente pode ter 20 $\%$ de atividades complementares que podem ser inseridas nessas 3.600 horas. I sso acabou reduzindo muito a carga horária de todas as escolas particulares. 0 próprio MEC permitiu isso. Então a cada mudança dessa, a gente precisa estar reajustando todas as disciplinas do currículo. É ruim para o aluno, porque se ele é reprovado em um determinado semestre, ele cai em outra grade, e aí tem que fazer adaptações. Mas essa revisão precisa ser feita sempre, e aí fazemos reunião de colegiado, reunião de seqüência (de projeto, de 
tecnologia, de urbanismo), reunião das disciplinas de fundamentação (desenho, AutoCAD, etc.). Além destas tem as reuniões por semestre para ver a coerência entre estas disciplinas, e depois se revisa o projeto pedagógico. No projeto pedagógico procurou-se distribuir as cargas horárias, equilibrar as disciplinas de história, de projeto de edificação, de projeto de urbanismo, as disciplinas de fundamentação e as disciplinas de tecnologia. Nos últimos tempos, eu percebi que as disciplinas de história tinham certa dificuldade em trabalhar com os alunos a leitura das plantas de edificação, assim como as análises de projeto. Então, reduziu-se um pouco da carga horária de história e introduziu-se nas disciplinas de projeto a obrigatoriedade dos professores estarem trabalhando com determinados arquitetos. Foi feita uma listagem de arquitetos importantes que não podem deixar de ser analisados, assim como os seus projetos. Essa listagem de arquitetos está relacionada com o conteúdo de cada semestre. Por exemplo, em um semestre que se trabalha muito a questão da forma, da luz, do espaço, dos cheios e vazios, estuda-se a obra do Louis Kahn. Aí o professor indica algumas obras para serem analisadas, e se estuda principalmente como o arquiteto resolvia e organizava os seus projetos. Tem arquitetos brasileiros, como Lina e outros que não podemos deixar de analisar os projetos, os cortes e as elevações. Mas nem sempre o professor consegue dar conta disso. Então, preciso estar realmente checando se o professor em sala de aula está dando conta de tudo isso.

- Existe uma referência teórica inicial nas aulas de projeto?

- Por exemplo, na hora de fazer estudo de caso de edificações escolares, os alunos vão estudar uma escola do arquiteto Paulo Mendes da Rocha, uma escola de outro autor, e vão analisar as plantas. A disciplina de projeto arquitetônico tem sempre pelo menos 50 minutos de aula teórica. É padrão para todos os semestres e todas as semanas. É lógico que quando chega o final da disciplina, existe um tempo maior para as orientações e atendimentos. Mas, pelo menos a cada 15 dias tem 50 minutos de aula teórica. Para isso, o professor tem que preparar a sua aula e trazer não só referências, mas elementos que colaborem na organização do projeto. 
- Houve alguma referência para a criação do Projeto Pedagógico? E para estipular as cargas horárias das disciplinas? Qual é a carga horária dessa faculdade?

- O primeiro projeto pedagógico foi criado em cima de outra experiência de coordenação. Na verdade, foi uma experiência que não foi implantada. Eu já havia trabalhado muito tempo em um determinado projeto pedagógico e por uma circunstância de redução de horas, tivemos que mudar. No final, eu trouxe para cá algumas coisas e consegui fazer as alterações.

- 0 que existia antes?

- Existia um conflito. Como as disciplinas eram muito vagas, cada professor mudava a sua ementa, o seu conteúdo e não existia uma linha ou uma diretriz que alinhasse todas as disciplinas. Cada professor entrava em sala de aula e dava o que queria, perguntando o que o aluno tinha visto na disciplina anterior. $E$ não é assim que funciona. É preciso ter uma linha geral e os professores precisam se pautar nela. A ementa não pode ser mudada porque é a coordenação e o seu colegiado que a determina. Já os conteúdos ficam mais livres para que os professores modifiquem dentro da ementa principal.

- Como é feita a preparação das aulas?

- O professor faz e entrega antes do início das aulas, o plano da disciplina. Ele pega a ementa que já existe, os conteúdos que já estão no projeto pedagógico, faz uma revisão, revisa a bibliografia (básica e complementar) que precisa estar disponível na biblioteca, e entrega para a coordenação. No primeiro dia de aula, ele entrega para os alunos. $\mathbf{O}$ detalhamento dos programas das disciplinas de projeto, 0 professor passa diretamente para os alunos.

- Você orienta o conteúdo de cada disciplina?

- O projeto pedagógico já diz isso, mas nós temos tabelas de seqüência também. Então, o professor sabe aonde tem que começar o conteúdo da disciplina e onde tem que terminar. Ele já sabe qual é o conteúdo da disciplina seguinte e qual o conteúdo da disciplina anterior. $\mathbf{O}$ professor da seqüência tem que saber exatamente como é o conjunto da disciplina. 
- Houve alguma intervenção do MEC neste assunto? Como foi?

- Por exigência do MEC, não. $O$ curso tirou nota máxima no projeto pedagógico, por isso não foram feitas alterações. $O$ curso existe desde 1999. $O$ ano que vem completa 10 anos, seis anos que estou na coordenação. A primeira turma acabou se formando com uma grade que era do projeto pedagógico antigo, e a revisão foi feita em cima de algumas alterações que o MEC solicitou. Já a última turma que se formou estava com o projeto pedagógico bem redondo.

- A disciplina referente à introdução do ensino de projeto - Projeto 1, também deveria ter o papel de complementação da formação artística?

- A parte artística tem sempre que estar presente em todas as disciplinas de projeto arquitetônico. Não há tempo para trabalhar a representação, assim como a expressão. Nos dois primeiros semestres, a gente não deixa os alunos usarem o AutoCAD, para eles poderem trabalhar o traço, a representação, a perspectiva e a observação. Nos dois primeiros projetos, eu não acho que seja bom aceitar projeto feito no computador. $O$ aluno tem que fazer muitos croquis. Nas outras disciplinas também. Tem uma disciplina que se chama Laboratório de Arquitetura e outra que se chama Laboratório de Urbanismo, onde fizemos uma integração vertical. Nessa disciplina estão presentes alunos desde o primeiro até o sexto semestre, misturados, tendo aula no mesmo dia e fazendo a mesma atividade projetual. Cada semestre é uma atividade diferente. Este semestre os alunos fizeram modelagem de terrenos com topografia acidentada. Percebeu-se que os alunos estavam com muita dificuldade na disciplina de urbanismo e a topografia só não davam conta. Então, alunos do primeiro ao sexto semestre trabalharam o mesmo tema, pequenas praças, em locais íngremes. Foi a oportunidade de trabalhar várias questões, mas sempre com representação à mão livre. Estamos percebendo resultados bem interessantes. Os alunos que já aprenderam, querem apresentar em AutoCAD, então pedimos para eles redesenharem, para aprender também a trabalhar com lápis e papel manteiga.

- Como o Sra. vê as duas abordagens das disciplinas projetuais: uma fundamentando a formação artística e sensível e a outra em que o aluno já inicia o aprendizado de projeto, projetando? 
- Aprender projeto na disciplina de projeto 1 sem o aluno saber desenhar, é muito complicado, ainda mais nos dois primeiros meses de aula. Agora, depois desses primeiros semestres, trabalhar com coisa abstrata, que não tem terreno, não tem implantação, não tem referência, é muito tarde.

- Você acha que o aluno deve aprender projeto "de cara" na disciplina de Projeto 1?

- Sem o aluno saber desenhar, não.

- Qual seria a prioridade de um curso introdutório de projeto?

- Primeiro semestre é leitura. No segundo semestre já dá. Na hora em que o aluno começou a aprender a desenhar, já tem condições de começar a projetar. Você passou pela faculdade pública também, e deve lembrar que nós não sabíamos nem pegar no escalímetro no primeiro ano. Só quem sabia eram os alunos que tinham feito escola técnica. Por causa disso os projetos saíam péssimos. A gente não sabia representar, e na primeira aula os professores já pediam desenho. Não existia disciplina de desenho arquitetônico. Projetar sem saber desenhar é como fazer uma redação sem saber português, sem saber quais são as letras do alfabeto e como são as sílabas. E para fazer redação você precisa ter um repertório. A aquisição de um repertório é o objetivo dos primeiros semestres.

- Como o Sra. vê a transmissão do conhecimento de referências arquitetônicas nas disciplinas projetuais?

- Os primeiros semestres trabalham com referências, com percepção do espaço, enfim, com a representação do espaço que o aluno começa a perceber. Tanto o espaço das edificações quanto das cidades. Aqui as disciplinas de urbanismo aparecem desde os primeiros semestres.

- Agindo como se a faculdade privada realmente utilizasse algumas disciplinas do primeiro ano da graduação para a formação artística e sensível do futuro arquiteto, o Sra. diria que esse preparo é suficiente para o aluno adentrar no mercado de trabalho?

- Não é o ideal, é o mínimo para o aluno recém-formado entrar no mercado de trabalho. Da maneira como o MEC reduziu a carga horária 
dos cursos de graduação, o aluno vai necessitar de especializações constantes. A formação que a graduação dá é o mínimo suficiente para o aluno ter idéia de cada aérea. Ele precisa fazer estágio, passar por alguns escritórios. Ao começar a trabalhar, o próprio aluno vai sentir necessidade de fazer uma complementação. Aí, ele vai voltar ( para a faculdade) e começar os cursos de extensão e de especialização.

- Aqui tem?

-Temos uma proposta, mas não conseguimos formar uma turma. A maioria dos alunos recém-formados tem ido para a faculdade pública - Vários alunos já estão fazendo mestrado lá. As escolas todas estão tentando criar. As Belas Artes têm curso de extensão, a UNI 9 também tem. Nossos preços eram caros e como a faculdade pública aceita alunos ouvintes, muitos dos nossos alunos acabaram indo pra lá. Mas a gente tem intenção de reforçar um projeto que se chama Arquitetura e Cidade. $O$ outro é de Paisagismo. Mas muito mais prático: plantio, execução, assuntos que não conseguimos dar na graduação.

- Uma das inquietações com relação a uma divergência entre o ensino da universidade pública em comparação ao ensino efetuado na universidade privada é que a primeira pretende formar os arquitetos para a sociedade enquanto que a segunda forma arquitetos para o mercado de trabalho. 0 que o Sra. pensa disso?

- Eu não acho que se deva formar arquiteto somente para o mercado de trabalho. Os arquitetos são formados para a sociedade e para o mercado de trabalho que são uma coisa só. $\mathbf{O}$ arquiteto jamais pode esquecer-se da função social, mas também não pode só trabalhar para o social. Trabalhar para o social não quer dizer trabalhar para os pobres apenas. Formar para o mercado de trabalho, talvez seja a função dos cursos tecnológicos e não dos cursos de graduação, que precisam ter uma visão mais ampla, porque o mercado de trabalho muda muito rapidamente. $O$ que o arquiteto tem que receber como formação e informação têm que ser suficiente para ele acompanhar as mudanças no mercado de trabalho e na sociedade. Não acho que existam faculdades formando para o mercado somente. Acho que é inerente a profissão do arquiteto se preocupar também com as 
questões sociais, só que não é ele que resolve as questões sociais. 0 arquiteto é só um dos elementos, um dos instrumentos com massa crítica e propositiva para colaborar na solução dos problemas da sociedade e do mercado. Sem uma resposta coerente para essas duas coisas, o arquiteto não faz arquitetura, não faz a cidade. Esta é a minha visão. Não vejo diferença e não acho que aqui estejamos formando profissionais só para o mercado. $O$ arquiteto formado aqui consegue se enquadrar. Por exemplo, eu não tenho nenhum aluno no décimo semestre que não consiga fazer estágio. Se não consegue, é porque ele já trabalha na área. Todos os alunos a partir do terceiro semestre (praticamente $90 \%$ ) conseguem se enquadrar no mercado. E muitas empresas pedem para o $\mathrm{CIEE}$, para essas agências, alunos daqui. Em geral, os alunos formados aqui têm uma boa colocação no mercado. Mas não é para este mercado que a gente tem formado apenas. Eu acho que $o$ arquiteto tem que ter noção do todo. Noção de como o mercado e a sociedade funcionam.

- Quais são as disciplinas que complementariam as aulas de projeto? Existem aulas de desenho? Como são?

- Existem aulas de desenho arquitetônico. Não há tempo para disciplinas como desenho de observação ou desenho artístico. São dois dias por semana, e equivalem a 160 horas.

- Qual é o perfil profissiográfico que a escola pretende para o aluno? É direcionado ao mercado? Como? Por quê?

- O perfil profissiográfico não é diretamente ligado ao mercado. Mas o que reforçamos aqui é a questão da construção. Acho que esta questão diferencia a faculdade de algumas linhas que tem por aí, que se voltam mais para a questão plástica da arquitetura. A grade aqui acaba dando mais importância para a construção, os materiais e as tecnologias. Por isto se reforça a representação que é fundamental para o projeto.

- Como são as instalações, por exemplo, o auditório?

- O auditório daqui é plano, não tem desnível, e tem capacidade para 160 pessoas. Como a gente tem pouco espaço no campus, quando queremos fazer grandes exposições, tiramos as cadeiras e montamos os displays. 
- Como são desenvolvidas as maquetes?

- Tudo é feito aqui, na maquetaria. Tem dois técnicos que ajudam. Nos primeiros semestres os alunos são muito incentivados a trabalhar com maquetes. Basicamente, a prioridade é o desenho e depois, o trabalho com maquetes. Trabalha-se com todos os materiais, madeira, papel, papelão. Se o aluno quiser trabalhar com madeirabalsa ou com madeira maciça, tem serra, tem lixadeira, tem tudo.

- Tem arquivos de mapas?

- Na biblioteca tem um acervo de mapas e no laboratório de informática tem uma base com diversos mapas digitalizados. E no escritório-modelo tem mais algum material.

- Como é o escritório-modelo?

- O escritório-modelo faz parte da grade curricular, são 80 horas de estágio. Tem sempre um professor e a gente presta serviço para a comunidade. Atualmente, estamos fazendo um mapa-tátil para a Fundação Dorina Nowill. Estamos também trabalhando com um grupo sócio-educativo que é uma ONG. Esta ONG trabalha com crianças de 6 a 14 anos na pós-aula, para não ficarem na rua. São crianças em situação de risco que moram em cortiços da região da Aclimação. Elas recebem um atendimento para reforço de aula. São atividades como aulas de música, de dança, passeios ao parque, jogo de bola, ida ao cinema. Todo o tempo que a criança tem livre, ou de tarde, ou de manhã, ela fica neste núcleo sócio-educativo. E no escritório-modelo, desenvolvemos o projeto da brinquedoteca e da biblioteca. Foi feito o projeto de pintura das salas de atividades. Conseguimos que a Suvinil atuasse como parceira e doasse a tintas para esse projeto. 0 trabalho com os mapas-táteis é muito interessante. Está sendo executado um mapa que serve para o aprendizado dos cegos na disciplina de mobilidade. É um trabalho para os cegos conseguissem entender como são as ruas, como se localizar na quadra em torno da Fundação. A idéia inicial seria tentar vender a implantação de mapas-táteis em alguns órgãos públicos, tipo Metrô, grandes terminais de ônibus, para que os deficientes visuais consigam se localizar dentro das estações, nos shoppings, etc. Nós não cobramos o projeto, e também não fazemos projetos particulares. São sempre prefeituras, estado, ONGs, 
associações, escoteiros, secretarias de prefeituras, entre outros. 0 aluno pode fazer este estágio a qualquer momento. Conta na carga horária do último semestre. Como no último semestre o aluno tem janela, além do TFG, ele pode vir 1 ou 2 vezes por semana para completar a carga-horária.

- Com a redução da carga-horária, como ficaram as aulas de histórias?

- Foi passado um pouco do conteúdo da história para dentro das aulas de projeto. Essa é a seqüência de projeto. 0 primeiro semestre ficou com duas vezes por semana de aulas de desenho. Estuda-se o desenho, os espaços conhecidos, análise, crítica e representação; desenho, técnica e maquete; desenho de observação e desenho de proposição. Os temas são muito simples:

A casa, o pequeno atelier ou uma galeria, enfim temas que não possuam programas complexos. Os arquitetos estudados nesse semestre são Tadao Ando e Paulo Mendes da Rocha. I sto está sempre sendo reciclado. $O$ conteúdo da seqüência inclui textos destes arquitetos e bibliografias em geral. Já a introdução para o projeto de urbanismo começa com um pequeno projeto. Mas projeto mesmo, o aluno só vai ter no segundo semestre. Lá ele vai trabalhar a organização dos espaços, junto com as escalas e a complexidade. Por exemplo: qual é a medida necessária para se projetar um quarto ou um banheiro, antropometria, ergonomia, entrada de luz, a cor na arquitetura, entre outros. 0 tema muda, mas em princípio é a Vila. 0 tema foi escolhido porque é um pequeno espaço, um conjunto aonde o aspecto da relação da edificação com a cidade é estudado. E também tem a unidade habitacional. Os arquitetos de referência são o Neutra e o Oswaldo Bratke. Projeto de arquitetura no quarto semestre possui temas que variam entre biblioteca, capela. Os arquitetos estudados são o Alvar Aalto, Henri Ciriani e Louis Kahn. No quinto e no sexto semestre os alunos vão trabalhar a construção. Eles já tiveram as disciplinas de tecnologia, e podem pensar nos materiais ao fazer o projeto. Os temas de projeto englobam o brutalismo, abóbadas, treliças, diferentes vãos, que combinam com projeto de escolas, centro esportivo, terminal de ônibus entre outros. E no sétimo e oitavo semestre, há um preparo para o TFG. A questão da relação da edificação com a cidade. Isto porque no TFG nunca é uma edificação só no lote. Geralmente é um complexo que pega vários 
lotes ou um quarteirão ou são vários terrenos para os alunos fazerem o projeto com diretrizes para o conjunto. Senão, quando chegar o nono semestre o aluno não tem preparo para o TFG que precisa ter essa relação. $O$ TFG sempre é projetual e não pode ser só uma edificação no lote, mas tem que fazer todo o estudo do entorno. Os arquitetos de referência são Lina Bo Bardi, Niemeyer, Rafael Moneo, Foster. $O$ tema é o edifício multifuncional, com todo o estudo da legislação. Os programas mais complexos servem como preparo para o TFG. Às vezes o programa nem é tão complexo, mas o projeto pede grandes vãos, trabalhando com a questão da construção. É a disciplina de projeto que chega mais perto de pré-executivo.

Esta tabela é feita pela coordenação e pelos professores de projeto (colegiado) e como existe interface tanto com a história como a tecnologia, são feitos quadros também para a história e tecnologia.

Eu ensinaria esse conteúdo em qualquer faculdade.

O produto de cada uma dessas disciplinas vai depender muito do potencial dos alunos. Aqui tem alunos que são excelentes e não perdem nada para os alunos das escolas públicas. E tem também alunos que são muito fracos, assim como as públicas também têm. Em geral os alunos das escolas públicas têm uma formação muito melhor que os alunos das escolas particulares. Mas isto não quer dizer que o produto a ser apresentado no final do curso seja muito melhor do que o produto das escolas particulares. Eu acredito que o projeto pode ser ensinado, assunto que nas escolas públicas não está muito organizado. Existe método, organização, o professor tem que preparar aula de projeto. 


\section{ENTREVISTA ${ }^{71}$ COM O PROFESSOR E ARQUI TETO DR. CARLOS EDUARDO ZAHN}

Sobre o nível dos alunos na faculdade privada:

- Eu acho que, de certa forma, existe diferença entre os alunos que entram em faculdade privada e os que entram em faculdade pública. Os alunos de faculdade privada ou vem de colégio público ou vem de outros colégios que estão com os mesmos problemas dos colégios públicos. $O$ fato de não haver ensino artístico no ensino fundamental e médio é um grande problema. Não há nem ensino artístico, nem ensino de caráter técnico ligado a expressão gráfica, como as disciplinas de desenho geométrico e geometria descritiva. A expressão projetual no fundo é a aplicação da geometria descritiva. Fora isso, a deficiência na formação artística, impossibilita distinguir ou conceber coisas, ter idéias sobre valores artísticos ou sobre expressão gráfica. Essa é a grande dificuldade, maior talvez pra quem está em faculdade privada.

Sobre a criação do projeto pedagógico:

- Esse projeto pedagógico (O projeto pedagógico da Faculdade X) já existia quando eu entrei na faculdade por volta de 1997. O projeto pedagógico é do tempo da professora Dra. Maria José Feitosa. Foi feita uma adaptação, um pouco antes de assumir a coordenação. Durante um período de seis meses, eu fiquei como coordenador de "projeto". O projeto existente tinha algumas divergências com relação a que o MEC pedia no último ano de graduação. Foi feito o ajuste para o TFG, entre outras coisas. No momento em que eu assumi a coordenação, o projeto pedagógico já estava ajustado (menos quanto ao TFG).

Sobre a visita da comissão do MEC em 2000:

- Você se lembra que, quando veio a comissão do MEC com a professora Silvia Ficher, eles liam o projeto e pediam para alterar tal assunto e trazer de volta para ser analisado. 0 resultado era aceito e

${ }^{71}$ Entrevista realizada com o arquiteto e professor Dr. Carlos Eduardo Zahn em 24/11/2008. 
outra vez era feito outro pedido de modificação. No final o resultado foi bom.

Sobre a intervenção do MEC no Projeto Pedagógico da faculdade:

- A diretriz que valia naquele tempo era basicamente a portaria 1770, de 1974. Agora é outra norma, a resolução NO. 6, do ano de 2006. Sobre a estrutura, não foi feita nenhuma modificação no curso. As diretrizes do MEC não falam de disciplinas de complementação de deficiências, então se supõe que esta questão esteja incluída no conteúdo programático das disciplinas dos primeiros anos. É, mais ou menos, o que os professores fazem, sem uma diretriz maior. No caso específico do plano pedagógico dessa faculdade há uma possibilidade de se fazer algum curso aos sábados para complementar uma ou outra disciplina. I sso nunca aconteceu, mas poderia ter acontecido.

Sobre o desenvolvimento das disciplinas no primeiro ano do curso:

- O primeiro ano encontra os alunos de uma maneira e tenta entendêlos, para, a partir daí, introduzir o que for necessário. 0 grande problema é que alunos chegam à faculdade sem noção de representação gráfica. Por isso existe a disciplina de Desenho para Arquitetura 1 e 2 (no primeiro e no segundo semestre). Tanto a disciplina de Projeto 1 como a de Projeto 2, são "alimentadas" por Desenho para Arquitetura 1 e 2.

De certa maneira o Desenho para Arquitetura 1 seria a representação gráfica que os alunos deveriam conhecer durante o ensino médio, e que serviria para eles aplicarem no Projeto 1. Mas como eles chegam à faculdade crus, a alternativa é aprender junto com Projeto 1.

Sobre o tema utilizado na disciplina de Projeto 1:

- Hoje, eu não sei exatamente o que os professores estão usando como procedimento pedagógico e quais exercícios. Entretanto, existe essa preocupação de utilizar a disciplina de Projeto 1 para explicar aos alunos o que é projeto.

Eu, particularmente, acho que a disciplina de Projeto 1 não tem que ter um tema para fazer projeto. $O$ aluno tem que compreender dimensionamentos, saber noções de antropometria, qual o espaço ocupado para uma mesa, o espaço necessário para uma pessoa 
circular com conforto. Enquanto isso é ensinado, os alunos vão aprendendo a desenhar no Desenho 1. Após essa etapa é que começa a parte de composição de um projeto. Eu me lembro do meu tempo de FAUUSP: no primeiro ano a gente não fazia projeto. Os alunos queriam fazer projeto; aí os professores davam projeto pra fazer, mas não era isso o que os professores queriam cobrar. Eles queriam cobrar se a gente sabia desenhar. Era mais ou menos por aí.

Comentário sobre a afirmação da professora Dra Silvia Ficher que dizia que o curso de arquitetura precisava ser mais agradável para o aluno que estava ingressando (por conta da visita do MEC):

- Eu lembro que, naquela época, essa foi uma das mudanças realizadas, a partir da solicitação do MEC. $O$ curso do primeiro ano antes da visita da comissão do MEC tinha disciplinas como Cálculo 1, Física 1, Desenho 1 e nenhuma de projeto ou de história da arte. A professora Silvia Ficher perguntou: "Poxa, deve desistir muita gente durante o primeiro semestre neste curso, não é?". Eu respondi: "Até desiste, mas por que?" Ela respondeu: "Por que o curso é muito "chato". Tem que introduzir os alunos no projeto. Ao colocar todas as disciplinas tecnológicas no começo 0 curso pode parecer desinteressante. Foi então que transferiu-se Calculo 1 para o segundo semestre ou terceiro. Física 1 também foi tirada do primeiro semestre, no lugar foi trazida a disciplina de Projeto 1 alinhada com Desenho 1. Junto foi trazida a disciplina de Introdução à Arte e Arquitetura, para se ter noção de história. Não um curso de história aprofundado, mas conhecimentos básicos de repertório. I sso mudou um pouco o Projeto Pedagógico inicial, para o Projeto Pedagógico 1, que foi o que valeu de 2000 até 2004. As pessoas que ingressaram em 2004 e estão saindo agora, estão acompanhando o Projeto Pedagógico 2, e finalmente, o pessoal que entrou em 2007 acompanha o Projeto Pedagógico 3, devido a formação intermediária como design de interiores, (dois anos depois do ingresso na faculdade) . "Esse projeto eu não conheço (o terceiro)", mas no fundo não é muito diferente. De qualquer forma, a formação artística foi trazida para o primeiro semestre porque fazia falta. Algumas noções de tecnologia de construção eram aprendidas superficialmente, não sobre os tipos de materiais, mas como eram os elementos de 
tecnologia, para mergulhar os alunos na visão do que é arquitetura. Essa foi a mudança de 2000, e quase tudo, continua valendo até hoje.

Sobre o nível de conhecimento básicos da Língua Portuguesa dos alunos dessa faculdade:

- Bem, o curso não tem disciplinas de complementação formais, elas são dadas através de próprias disciplinas da graduação. Quanto a Língua Portuguesa o que a gente percebe é o seguinte: não é só o ensino artístico que vem deficiente do ensino fundamental, o ensino básico de língua portuguesa também é muito ruim e as pessoas escrevem mal. Além dos problemas de ortografia, os alunos não conseguem estruturar a lógica do texto. Essa seria a função da disciplina chamada IPA (Introdução à Produção Acadêmica 1 e 2), que ensina a metodologia de trabalho acadêmico e LPT ( Leitura e Produção Textual). Essa disciplina ajuda os alunos expressar melhor o seu pensamento, porque o projeto além da parte gráfica contém a parte escrita (relatório) ou mesmo a descrição do partido arquitetônico. De certa forma, estas matérias são especialmente para isso, mas elas não cobrem tudo. Principalmente a parte gráfica tem de ser coberta através de um desenho para a arquitetura, que não deixa de ser uma matéria específica. Não precisaria se os alunos entrassem na faculdade conhecendo geometria descritiva ou perspectiva técnica. Na faculdade pública, nos velhos tempos, havia uma disciplina de geometria descritiva, que durava um ano inteiro. Hoje não dá tempo de ensinar tudo, nem mesmo com esta disciplina específica de desenho.

Sobre como deve ser a disciplina de Projeto 1 no primeiro ano:

- O ensino de projeto no primeiro ano tem que ser uma imersão no fato projetar. $\mathrm{O}$ aluno precisa conhecer o repertório arquitetônico e entender que o projeto é um resultado artístico. Precisa conhecer também a parte tecnológica e saber como representar isso. A maioria dos cursos de graduação em arquitetura é semestral. De certa forma, o primeiro semestre, seria para suprir alguma deficiência existente no ensino fundamental e médio, mas isto pode ocorrer ao longo do curso.

Sobre as cargas horárias das disciplinas: 
- O MEC não gera cargas horárias para disciplinas, ele simplesmente estipula tipos de conteúdo que devem ser desenvolvidos, e aí cabe à instituição montar o seu projeto pedagógico. É evidente que ninguém vai fazer o projeto pedagógico utilizando 100 horas de projeto durante o curso inteiro. É lógico que vai ter muito mais projeto do que história da arquitetura grega, ou qualquer coisa que o valha. A distribuição das cargas horárias pelas diversas disciplinas é uma ação que se monta com certa lógica. As cargas principais são de projeto arquitetônico, o conjunto das tecnologias (estruturas, materiais, conforto ambiental, acústica) no geral e a parte de história. A tendência atual é de "encolher" o curso de história. Nem sei se isso é bom.

Sobre as cargas horárias do curso de arquitetura em geral:

- O grande problema é que as escolas particulares, pelo menos as conhecidas apresentam uma carga horária menor. A faculdade que estamos falando possui quatro mil e trezentos e tantas horas (4.300 horas). Existe uma tendência, pelo menos nas escolas particulares de que o mínimo seja o máximo. O MEC exige três mil e seiscentas horas (3600 horas). Se for tirar 1000 horas ou 800 horas de alguma disciplina, para então caber nas 3600 horas exigidas, nem sei o que vai sair porque tudo o que já tem é pouco. Esta é uma grande questão. Não dá para fazer um curso comportando tudo o que o MEC exige, com o nível minimamente aceitável. Esse mínimo está abaixo do mundo real como passador da formação. Então, a tendência é "encolher" algumas coisas. Agora, a disciplina de projeto não dá para "encolher" mais. Tem a parte de urbanismo que eu já acho pouco, comparando, por exemplo, com o que tem de urbanismo e desenho urbano na faculdade pública ou em outras escolas públicas. Não adianta alguém dizer que a escola particular agora vai ter $\mathbf{7 0 0 0}$ horas. Pode até ter. Só que aí o mercado de ensino acaba ficando não atendido porque o curso que tem $\mathbf{7 0 0 0}$ horas tem que cobrar o dobro daquele que tem 3600 horas. E aí não tem mercado. Não é o mercado de ensino, mas sim o mercado de custo. E aí existem escolas e escolas. Existem escolas hoje, cuja mensalidade do curso de arquitetura passa de $\mathbf{R} \mathbf{\$} \mathbf{2 . 0 0 0 , 0 0}$. E tem escolas que o preço não chega em $\mathbf{R} \$ 1.000,00$. Hoje não sei se esta faculdade possui o curso mais barato, mas é um dos que custam menos. Por exemplo, o curso 
Faculdade $X$, a graduação em arquitetura e urbanismo está em torno de $\mathbf{R} \$ \mathbf{2 . 0 0 0 , 0 0}$. A Y deve ser por aí também. A $Z$ deve ser daí pra

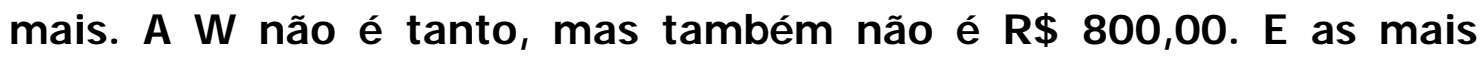
populares são as Faculdades $T, U, V, S$, que giram em torno de $\mathbf{R} \$ 1.000,00$ ou um pouco menos. Dentro do mínimo de horas eu acho que esta faculdade está oferecendo um pouco mais. São quase 1000 horas a mais que o mínimo, fazendo o que pode.

Observação:

Uma observação, que não foi tratada na entrevista: agora há uma nova norma que diz que o mínimo de 3600 horas deve ser em hora-relógio (60 minutos) e não mais em hora-aula (50 minutos). Assim, às 4320 horas-aula, equivalem a 3600 horas relógio (é como está a Faculdade agora.)

Sobre o conteúdo da disciplina de Projeto 1:

- Eu penso que no Projeto 1 não dá para sair projetando, porque os alunos não entendem nem o que é projetar. Eu acho que é fundamental na primeira abordagem fazer com que 0 aluno perceba $o$ que é projetar. Como? Vendo repertórios, pesquisando, eventualmente fotografando, visitando, digitando, tendo noções de arquitetura. Não é preciso que isto aconteça só na disciplina de projeto. Pode ser também na disciplina de arquitetura e arte. Ao mesmo tempo ele não precisa aprender desenho na disciplina de desenho. Ele experimenta algumas coisas em termos projetuais que não chega a ser projeto. Pode ser aplicação de antropometria, ver o que cabe em um espaço. Distribuir algumas coisas dentro de um espaço. No fundo isto é projetar. Não é projetar com um programa específico, mas é projetar entendendo o que é o espaço. Já é o primeiro passo. Se conseguir isto tudo no primeiro semestre já está mais que bom.

Sobre a divergência entre a universidade pública e a universidade privada:

- Aqui há uma divergência entre a universidade pública que prepara o arquiteto para a sociedade e a universidade privada para o mercado. Aí está o erro da universidade pública, porque além de preparar o aluno para a sociedade, tem que preparar para o mercado. Não é porque o aluno está na universidade pública que não deve trabalhar. Tem que trabalhar também. Na área privada tem o mesmo problema. 
A universidade privada tem que preparar o aluno para o mercado. Principalmente, porque lá tem gente que já trabalha e precisa regulamentar a situação e continuar no mercado. Não é porque ele é formado em uma universidade particular, qualquer que seja, que ele pode ser um "beócio" trabalhador. Tem que ser alguém que compreenda o mundo em que está, até para fazer projeto de acordo com certas características e atendendo a questões sociais. Questões de ambiente, questões de economia da sociedade, questões de percepção do mercado de trabalho. Mercado de trabalho, não mercado de trabalho emprego, mas mercado de trabalho de consumo do que está sendo produzido de arquitetura.

\section{Sobre as atividades complementares:}

Hoje, todos os cursos de arquitetura seguem a diretriz do MEC incluindo atividades complementares na carga horária do curso. São horas a mais que os alunos têm que cumprir fazendo outras coisas. Eu acho que estas atividades complementares podem, de certa forma, até contribuir para $o$ aluno perceber 0 mundo em que ele vai se inserir como profissional. Tanto sob o ponto de vista artístico, tanto sob o ponto de vista dos questionamentos sociais e econômicos. Eventualmente, até a percepção da importância do aluno em cursar uma escola de línguas (espanhol, inglês, etc.). Hoje, dependendo de onde o aluno trabalha, se ele não souber o mínimo de espanhol, ele não trabalha. Não sei se isso ainda é válido para o curso de arquitetura, mas quando a gente montou a primeira proposta, essa idéia era bem-vinda.

- Eu não sei se a instituição aceita atividades complementares diversificadas, mas acho que devia aceitar. Tudo isso contribui para que o aluno possa perceber o que está acontecendo para fora da janela. Hoje, se o aluno não percebe a dimensão dessa crise econômica que está acontecendo, provavelmente ele não vai ter clareza sobre certos condicionantes para fazer certos projetos. Entender como está o mercado da construção civil, o que de fato pode ser produzido com mais adequação, quais as tendências atuais e futuras. I sto não é só no primeiro ano, é durante o curso inteiro. 0 primeiro ano deve dar o primeiro passo para "cair a ficha". 0 aluno tem que perceber onde ele está. 
Sobre a definição do que é projeto:

Projeto não é resolver em AutoCAD uma planta e fazer o corte. É mais que isso. É também o oferecimento de um ambiente adequado, de uma situação urbana adequada, de condicionantes de caráter ambiental, de sustentabilidade pelo uso de materiais. Ao mesmo tempo é o ato de gerar uma expressão artística adequada ao momento em que vivemos. A professora Sylvia Dobry diz que as pessoas hoje não fazem projeto: "fazem caixinhas com buraquinhos". Ela fica exasperada com os alunos que não entendem a composição de um volume. Faz uma planta aqui, depois levanta uma fachada ali, depois uns quadradinhos de janela. Não é isto. Agora, estou nesse ponto da orientação dos trabalhos de TFG dos alunos. Eu digo: "Faça um volume disto e pense que tipo de expressão plástica você pretende para esse projeto. Se as janelas vão ser rasgos ou panos de vidro, se você quer valorizar a horizontalidade ou a verticalidade". Senão vira caixinha com buraquinhos. Mas isto tem que ser valorizado enquanto preocupação projetual, ao longo do aprofundamento da formação do aluno. Lógico que no primeiro ano o professor não vai cobrar conseqüências estruturais no projeto. 0 aluno nem conhece estrutura, não sabe nem o que é isto. Mas, conforme ele vai aprendendo coisas de conforto, de materiais, de estrutura, o projeto deve responder a essa relação de uso desses ingredientes tecnológicos e como isto vai ser interpretado em termos plásticos para ser um projeto coerente. Se ele não tiver intenção plástica, aí então vira "caixinha".

\section{Sobre o mercado de trabalho:}

O que a gente tem visto ao longo do tempo é que nem todos os formandos da faculdade A entraram no mercado de trabalho. Alguns foram fazer outras coisas também. Mas a verdade é que a universidade ao preparar alunos para a sociedade, preparou vários músicos, vários poetas, etc. Isso é positivo. Tem muita gente trabalhando no mercado de trabalho Nas universidades particulares, o que a gente vai percebendo é que muitos formandos vão entrando em certas faixas do mercado de trabalho que até pouco tempo atrás eram muito pouco valorizadas. Você falou que encontrou uma moça trabalhando na $C \& C$, como arquiteta. Hoje, saber especificar 
materiais é uma ocupação digna e necessária. Complementa a elaboração de um projeto. Tem que saber especificar o material de acordo com o resultado pessoal desejado. A questão de especificação de interiores está muito valorizada. Existem áreas no mercado de trabalho para os arquitetos que dominam técnicas de luminotécnica, de tratamento acústico de ambientes, etc.

- Acho que hoje o mercado de trabalho é muito grande. Não é só abrir um escritório ou prestar um concurso na prefeitura. Aliás, eu ouvi uma entrevista interessante na Radio Eldorado dizendo que o grande erro da sociedade atual é que grande parte dos formandos (não especificamente em arquitetura) estão se preparando para um concurso público e "se encostar". Que falta empreendedorismo. I sto é fatal, porque vai estar todo mundo "encostado" e ninguém produz coisa nenhuma. Eu acho que a arquitetura tem um monte de coisas para produzir: a questão da obra, ligada à questão de materiais, de tecnologias ambientais, ligada à questão de projeto. Até a questão da gestão pública tem várias falhas, basta olhar pela janela. Juntar a formação técnica com a projetual, com a cultural. No fundo, o curso de arquitetura é difícil de ser classificado. Seria de humanas, de tecnológicas ou exatas porque ele é um estranho no ninho em qualquer lugar. Se colocarmos o curso na área tecnológica, tem o artístico, não é só tecnológico. Se colocarmos o curso na área de Humanas, o concreto não é humano. 0 curso é livre, tem que ser livre.

Sobre o perfil profissiográfico do formando desta faculdade:

- Eu não gosto desta palavra. 0 projeto pedagógico desta faculdade, nem sei se lá tem tal palavra. Mas todos os projetos têm, e o desta faculdade também tinha. Mas quando eu descobri que essa palavra não existe no dicionário, eu resolvi mudar um pouco este conceito. Qual é o perfil profissional desejado para o egresso. Por isso é que é não gosto dessa palavra. Mas, enfim, perfil profissional, você lembrase desta pergunta: "qual é o arquiteto que essa universidade pretende formar?" Esta é uma pergunta feita pela comissão do MEC em 2000. E a resposta dada foi: "Não sabemos ainda, pois o curso é novo". Hoje depois de 10 anos, ou quase de dez anos de turmas formadas e pelo nível de preocupação que os alunos têm, pelo nível de abordagem que eles procuram dar no projeto do trabalho deles, 0 
curso começa a ter uma "cara". Em termos de equipamentos sociais há alguns, um percentual menor sobre questões de intervenções urbanas, alguns entram na linha de projeto de caráter comercial (projeto de hotel, projeto de edifício multiuso, ambiente gastronômico, projeto de um SPA, entre outros). É um curso diversificado. Eu acho que tem que ser mesmo. A universidade tem que dar oportunidade para a pessoa se encontrar no urbano, no intraurbano, no projeto de edificação, no projeto de equipamentos públicos, no design, até na comunicação visual. 0 curso não é comunicação visual, mas há alunos que valorizam isto, enquanto profissão. Eu acho que hoje, por exemplo, com a Lei da Cidade Limpa, que não pode mais encher a fachada de outdoors, o próprio edifício deve expressar alguma coisa. Principalmente o edifício comercial. Então, tem várias alternativas: tem que dar liberdade para que 0 aluno possa escolher o caminho que ele quer.

Sobre a formação diversificada:

Eu acho que tem algumas escolas, que procuram mais a arquitetura do edifício. Talvez, se for dividir o bolo em fatias, seja a fatia principal, mesmo nesta faculdade. Muita coisa de edifício tem caráter público, que é uma das preocupações primárias dos alunos. I sto nós não controlamos, mas vai se percebendo conforme ele vai chegando, inclusive no momento de optar pelo que ele vai fazer no TFG. Tem aluno que desde o quarto semestre já está pensando nisso. Oficialmente, junto ao curso, ele tem que começar a pensar no oitavo semestre. É o momento que ele tem a metodologia de aplicação para projeto, etc. No oitavo semestre ele vai olhando o tema até chegar ao décimo semestre para a produção projetual final. Então, é um perfil diversificado e eu acho que tem de ser mesmo. A Faculdade $\mathrm{W}$, por exemplo, é uma escola voltada para a edificação. A gente vê pela tendência dos projetos apresentados pelos alunos. Lá os alunos produzem menos projetos ligados a questão urbana. Já na Faculdade A existem muito mais projetos ligados às áreas urbanas. Planejamento como tradicionalmente era feito, também não tem não. São bem mais numerosas as intervenções no desenho urbano.

Neste curso, a maioria é projeto de edificações. São projetos comerciais, mas não são de grande porte. Tem um grande hotel internacional e uma clínica "pet” em um bairro de periferia. I nclusive, 
tem aluno projetando o seguinte: "nós nunca fizemos durante os cinco anos de curso, um projeto de habitação unifamiliar bem feita. É isto que eu quero fazer". Acho válido; lógico que quem faz um projeto em escala menor tem que apresentar uma coisa mais pormenorizada, de quem faz um hospital regional. A idéia é que os profissionais projetem sabendo em que contexto o objeto projetado será inserido. Não importa se é uma habitação ou um conjunto habitacional ou um hospital, ou uma intervenção na linguagem de Feng Shui. 


\section{Considerações Finais}

As considerações finais serão mostradas, primeiro por etapas, e em seguida, a constatação final do estudo deste tema.

Ao falar sobre o Capítulo 01, CONSIDERAÇÕES SOBRE A TRANSMI SSÃO DE CONHECI MENTO NA UNI VERSI DADE BRASI LEI RA, é esclarecido que os docentes, como formadores de arquitetos, incorporaram uma forma de transmissão de conhecimentos secular e ultrapassada, para registrar ensinamentos junto aos seus estudantes. Este formato passa por análises em outras áreas do conhecimento, especialmente a Educação. No ensino de arquitetura e urbanismo há certo mal-estar ao tocar nesse assunto, pois alguns arquitetos-professores tentam justificar a assimilação ou não de conteúdo por parte de seus estudantes pela citação da frase: arquitetura não pode ser ensinada, mas certamente pode ser aprendida. É como se os docentes em geral cobrassem apenas da parte discente uma solução para essa situação. Entretanto, ao ser analisada, fica evidente a necessidade do empenho e envolvimento das duas partes: docente e discente.

Durante a explanação do Capítulo 02, denominado BREVE HISTÓRI CO DO ENSI NO SUPERI OR BRASI LEI RO, além de reconstituir a historicidade da universidade brasileira, principalmente no período após o ano 1990, procurou-se destacar algumas singularidades das bases da educação, profundamente transformadas por reformas da legislação no período da ditadura militar. São demonstrados os dados de expansão do ensino superior privado de arquitetura e urbanismo, e como é necessário ao arquitetoprofessor estar atento a perda da qualidade do ensino.

Nos assuntos referentes à docência e à didática, a discussão que se propõe é trazer de outras áreas do conhecimento experiências onde os arquitetos-professores possam além de provocar a curiosidade dos estudantes pelo aprendizado, romper o "entendimento" feito às custas da memorização.

É também explicado o papel da pós-graduação onde é cobrada a implantação de um campo do conhecimento e de pesquisa relacionados ao ensino do projeto.

No Capitulo 03, A DOCÊNCIA NO ENSINO SUPERIOR DE ARQUITETURA, o problema da qualidade do ensino de arquitetura é analisada de maneira específica. São abordados os diversos temas que tem 
sido aplicados em diversas faculdades durante o ínício do curso de projeto arquitetônico na graduação e comentados seus respectivos resultados.

Logo após essa constatação é proposta uma nova estrutura do curso de projeto arquitetônico com base em estratégias que visem à ampliação do aprendizado discente.

Estas estratégias agem de maneira encadeada.

Primeiramente há a aplicação de uma aula expositiva dialogada para a classe de estudantes ingressante para escolher as obras mais conhecidas e seus respectivos arquitetos na cidade de São Paulo.

Em seguida são feitos os estudos de cada caso destacando as principais características e qualidades arquitetônicas de cada obra e o seu respectivo arquiteto.

A terceira etapa deste procedimento abrange as realizações dos seminários dos grupos, onde a classe estaria utilizando como principal operação do pensamento a atividade crítica, "julgando" cada obra por meio de um exame crítico das suas qualidades, seus defeitos e suas limitações, além de trocar e acumular novos conhecimentos entre os estudantes.

Deste ponto de vista é fundamental o resultado de cada entrevista e comentários mostrados nos capítulos Capitulo 04 e 05, denominados VISÕES DIVERGÊNCIAS para a averiguação da possibilidade de empreender esse plano. É proposto como desafio o Projeto de uma Livraria onde o estudante deverá incorporar características próprias de cada arquiteto estudado.

Neste momento ocorre a complementação entre 0 ensino e a aprendizagem, engedrando a atividade chamada pelas autoras Anastasiou e Alves de ensinagem.

Concluindo, seria importante que os cursos de Pós-Graduação na área da Arquitetura e Urbanismo reservem espaços maiores para a discussão de questões fundamentais como didática e técnicas para o ensino de projeto arquitetônico. 


\section{REFERÊNCI AS BI BLI OGRÁFI CAS}

ANASTASIOU, Lea das Graças C. e ALVES, Leonir Pessate. Processos de Ensinagem na Universidade. Joinville, SC: UNIVILLE, 2007.

ANASTASIOU, Lea das Graças C. e PIMENTA, Selma Garrido. Docência no Ensino Superior. São Paulo: Ed. Cortez, 2002.

ARANTES, Pedro F. Arquitetura Nova. São Paulo: Ed.34, 2002.

ARGAN, Giulio Carlo. Projeto e Destino. São Paulo: Editora Ática, 2001.

BAZZO, V. L. A constituição da profissionalização docente no ensino superior: desafios e possibilidades. In: Seminário de Pesquisa - Formação de professores: história, políticas e práticas, 2005, Florianópolis. Seminário de Pesquisa - Formação de professores: história, políticas e práticas - ANAIS. Florianópolis, SC: EDIUFSC, 2005.

BOAVENTURA, E. Universidade e Estado no Brasil. Piracicaba: Revista da Unimep, 1989.

BOURDIEU, Pierre. Razões práticas: sobre a teoria da ação. Campinas: Papirus, 1996.

CARSALADE, Flavio no artigo "Referências Metodológicas para um processo de Ensino em Projeto. in Marques, Sonia e Lara, Fernando (organizadores). Projetar: desafios e conquistas da pesquisa e do ensino de projeto. Rio de Janeiro: EVC, 2003.

FREIRE, Paulo - Pedagogia da Autonomia - Saberes Necessários à Prática Educativa - São Paulo: Paz e Terra, 1996.

GHIRALDELLI J R, Paulo. História da Educação. São Paulo: Cortez, 1991.

GUEDES, Joaquim in "Geometria Habitada" no prefácio Eupalinos ou O Arquiteto, Valery, Paul, = Eupalinos ou L'Architecte; tradução de Olga Reggiani; edição bilíngüe: francês e português. Rio de Janeiro: Ed.34, 1996, 192p. 
GREGOTTI, Vittorio. Território da Arquitetura. São Paulo, Perspectiva, 1975.

HERTZBERGER, Herman. Lições de Arquitetura. São Paulo: Perspectiva, 1972.

LARA, Fernando e MARQUES, Sonia (org). "Desafios e conquista da pesquisa e do ensino de projeto" in Projetar: desafios e conquistas da pesquisa e do ensino de projeto. Rio de Janeiro: EVC Editora Virtual Científica, 2003.

PINTO, Valeska P. e EIRAS, I sabel Cristina. Reflexões da Professora Maria Elisa Meira. Piracicaba, SP: Editora UNI MEP, 2001.

PRONSATO, Sylvia Adriana Dobry. Arquitetura e Paisagem - projeto participativo e criação coletiva. São Paulo: Ed. Annablume, FAPESP, Fupam, 2005.

PRONSATO, Sylvia Adriana Dobry. Para quem e com quem: Ensino de Arquitetura e Urbanismo. São Paulo: FAU-USP, 2007. Tese de Doutorado.

RHEINGANTZ, PAULO A. no artigo "Arquitetura da Autonomia: Bases Pedagógicas para a renovação do Atelier de Projetos de Arquitetura" in MARQUES, Sonia e LARA, Fernando (organizadores). Projetar: desafios e conquistas da pesquisa e do ensino de projeto. Rio de Janeiro: EVC, 2003.

SANTOS, Milton. O professor como intelectual na sociedade contemporânea. In: Anais do IX ENDIPE, v. III. Águas de Lindóia, 1998.

SCHÖN, Donald A. La formación de profesionales reflexivos. Barcelona. Paidós. 1992.

SEGAWA, Hugo (org.) Arquiteturas no Brasil/Anos 80. São Paulo: Projeto, 1988.

SEVERINO, Antonio J. Educação, sujeito e história. São Paulo: Olho d'Água, 2001.

SILVA, Elvan. Uma introdução ao projeto arquitetônico. Porto Alegre: Editora da UFRGS, 2006. 
VALERY, Paul in Eupalinos ou O Arquiteto; tradução de Olga Reggiani; edição bilíngüe: francês e português. Rio de Janeiro: Ed.34, 1996, 192p.

VEIGA, Ilma A. (org). Caminhos da profissionalização do magistério. Campinas. Papirus. 1998.

VELOSO, Maísa e Elali, Gleici, no artigo "A pós-graduação e a formação do (novo) professor de projeto de arquitetura" in Marques, Sonia e Lara, Fernando (organizadores). Projetar: desafios e conquistas da pesquisa e do ensino de projeto. Rio de Janeiro: EVC, 2003.

VILANOVA ARTIGAS, João Batista. Caminhos da Arquitetura. São Paulo: Ed. Martins Fontes, 1986.

XAVIER, A., (org). Arquitetura Moderna Brasileira: depoimento de uma geração. 2. ed. São Paulo: Cosac \& Naify, 2003.

ZANETTINI, Siegbert. Arquitetura, Razão, Sensibilidade. São Paulo: Edusp/Imprensa Oficial, 2002.

ZEIN, Ruth. O lugar da crítica. Ensaios oportunos de arquitetura. Porto Alegre: Editora Ritter dos Reis, São Paulo: Proeditores, 2002. 


\section{BI BLI OGRAFI A}

ANASTASIOU, Léa Graças Camargos. Metodologia do Ensino Superior: da prática docente a uma possível teoria pedagógica. Curitiba: IBPEX, 1998.

ARGAN, Giulio Carlo. História da Arte como História da Cidade. São Paulo: Ed. Martins Fontes, 1992.

BENEDITO, Vicente e outros. La formación universitaria a debate. Barcelona: Universitat de Barcelona, 1995.

BRUNET, Cesar Martinell. Conversas com Gaudi. São Paulo: Perspectiva, 2007.

CASTANHO, Maria Eugênia. Universidade à noite : fim ou começo de jornada. Campinas: Papirus, 1989.

CHAUI, Marilena. Escritos sobre a Universidade. São Paulo: Editora Unesp, 2001.

GREGOTTI, Vittorio. Território da Arquitetura. São Paulo: Perspectiva, 1975.

GUEDES, Joaquim. Um Projeto e seus Caminhos. São Paulo: FAUUSP, 1981. Tese para Livre Docência.

HeRTZBeRGeR, Herman. Lições de Arquitetura. São Paulo: Perspectiva, 1972 .

LIBÂNEO, J osé C. Adeus professor, Adeus professora? São Paulo: Cortez, 1998.

MASETTO, Marcos T. Professor universitário: um profissional da educação na atividade docente. In: Masetto (org.).Docência na universidade. Campinas: Papirus, 1998.

PESSOA, Denise F. Utopias e Cidades: Proposições. São Paulo: Editora Annablume, 2006. 
PIMENTA, Selma G. A Didática como mediação na construção da identidade do professor: uma experiência de ensino e pesquisa. in André, M. \& Oliveira, M. R. (orgs.). Alternativas do Ensino de Didática. Campinas: Papirus, 1997.

PIMENTA, Selma G. A prática (e a teoria) docente re-significando a Didática. In: Oliveira (org) Confluências e divergências entre Didática e Currículo. Campinas: Papirus, 1998.

PIMENTA, Selma G. (org.). Saberes pedagógicos e atividade docente. São Paulo: Cortez, 1999.

SACRISTÁN, G. J. Poderes Instáveis em Educação. Porto Alegre: Artes Médicas, 1999.

SCHÖN, Donald A. La formación de profesionales reflexivos. Barcelona: Paidós. 1992.

\section{SITES}

ABEA (Associação Brasileira de Ensino de Arquitetura e Urbanismo): http://www. abea. arq.org.br/diretrizes.html. Requisitos para abertura e funcionamento dos Cursos de Arquitetura e Urbanismo, quanto ao corpo docente.

BARONI, Larissa Leiros. Ensino Superior nacional ganha 4,5 milhões de alunos http://www.universia.com.br/materia/imprimir.jsp?id=16885. Acesso disponível em $12 / 11 / 2008$.

BORTOLOTI, Fernanda da Silva. O Ratio Studiorum e a Missão no Brasil. Revista História Hoje. Revista Eletrônica de História, V.1N.2.UNESP, Franca, dezembro 2003. Disponível em: http://www. anpuh.uepg.br/historiahoje/volln2/volln2.htm. Acessado em 17/11/2009.

LIMA, Daniela Fernanda Cardoso Forster. Ratio Studiorum: Método Pedagógico dos Jesuítas. UNIMEP, 2007. Disponível em:

$<$ http://www. unimep.br/phpg/mostraacademica/anais/5mostra/5/31.pdf> Acessado em 10/12/2008.

A Tabela 1: população residente, por situação de domicílio e sexo, segundo grupos de idade - Brasil.encontra-se disponível no site <http://www.inep.gov.br/imprensa/noticias/censo/escolar/news08_01.htm> Acessado em 13/10/2008.

Ver o site da FAUUSP: http://www.usp.br/fau/ensino/pos/index.html. Acesso disponível em $13 / 03 / 2008$. 